\title{
Tumor angiogenesis : an in vitro study
}

Citation for published version (APA):

Lichtenbeld, H. H. C. (1993). Tumor angiogenesis : an in vitro study. [Doctoral Thesis, Maastricht University]. Datawyse / Universitaire Pers Maastricht. https://doi.org/10.26481/dis.19930930hl

Document status and date:

Published: 01/01/1993

DOI:

10.26481/dis.19930930hl

Document Version:

Publisher's PDF, also known as Version of record

\section{Please check the document version of this publication:}

- A submitted manuscript is the version of the article upon submission and before peer-review. There can be important differences between the submitted version and the official published version of record.

People interested in the research are advised to contact the author for the final version of the publication, or visit the DOI to the publisher's website.

- The final author version and the galley proof are versions of the publication after peer review.

- The final published version features the final layout of the paper including the volume, issue and page numbers.

Link to publication

\footnotetext{
General rights rights.

- You may freely distribute the URL identifying the publication in the public portal. please follow below link for the End User Agreement:

www.umlib.nl/taverne-license

Take down policy

If you believe that this document breaches copyright please contact us at:

repository@maastrichtuniversity.nl

providing details and we will investigate your claim.
}

Copyright and moral rights for the publications made accessible in the public portal are retained by the authors and/or other copyright owners and it is a condition of accessing publications that users recognise and abide by the legal requirements associated with these

- Users may download and print one copy of any publication from the public portal for the purpose of private study or research.

- You may not further distribute the material or use it for any profit-making activity or commercial gain

If the publication is distributed under the terms of Article $25 \mathrm{fa}$ of the Dutch Copyright Act, indicated by the "Taverne" license above, 
TUMOR ANGIOGENESIS: AN IN VITRO STUDY 
Cover Design: Rens ten Hagen, Architect

1)ruk: Daliwyse/(lniversitaire Pers Maasiricht

('IP-I)ATA KONINKLIJKE BIBL.IOTHEEK, DEN HAAG

L.ichlenbeld, Hera Henrica Corine

Tumor angiogenesis: an in vitro study / Hera Henrica

Corine Lichtenbeld. - Maastricht : Universitaire Pers

Miaastricht. - III.

Thesis Malastricht. - With ref. - With summary in Dutch.

ISBN 9(1)-5278-091-9

Subject headings: endothelial cells ! tumor angiogenesis 


\section{TUMOR ANGIOGENESIS: AN IN VITRO STUDY}

\section{PROEFSCHRIFT}

ter verkrijging van de graad van doctor

aan de Rijksuniversiteit Limburg te Maastricht, op gezag van de Pro-Rector, Prof. dr. L. Boon, volgens het besluit van het College van Dekanen, in het openbaar te verdedigen op

donderdag 30 september 1993 om 16.00 uur

door

Hera Henrica Corine Lichtenbeld

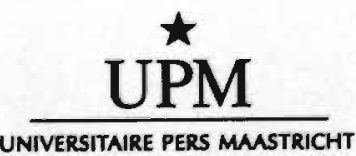




\section{Promotores:}

Prof.dr. G.H. Blijham (Rijksuniversiteit Utrecht)

Prof.dr. M.C.E. van Dam-Mieras (Open Universiteit Heerlen)

\section{Beoordelingscommissie:}

Prof.dr. H.A.J. Struijker-Boudier (voorzitter)

Prof.dr. R.K. Jain (Harvard University, Boston MA, USA)

Prof.dr. P.W. de Leeuw

Prof.dr. J.J.M. Marx (Rijksuniversiteit Utrecht)

Prof.dr. R.F.A. Zwaal 


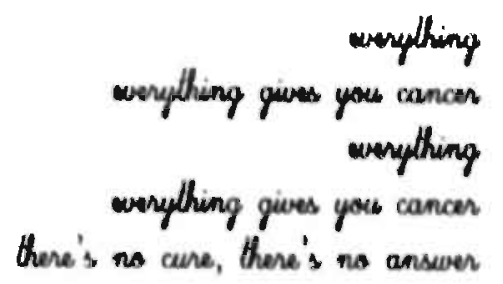

Pre fachson, 1982

Voor mijn ouders en Joost 
Chapter 1. Tumor angiogenesis: an introduction.

Chapter 2. Development of an in vitro proliferation assay.

(Angiogenesis: Key principles, Science, Technology, Medicine. R. Steiner, PB Weisz and $R$. Langer, Eds. Birkhäuser Verlag Basel, 261-265, 1992).

Chapter 3. Mitogenic properties of tumor spheroids for endothelial cells are related to their age. (Endothelium 1993, in press).

Chapter 4. Tumor spheroid induced vesicle formation on endothelial cells is associated with procoagulant properties. (J. Cell Science 1993, accepted)

Chapter 5. Lipid peroxidation of the endothelial cell membrane: a possible mechanism in tumor angiogenesis?

Chapter 6. Mast cells modify tumor-induced procoagulant properties of endothelial cells. (Thromb. Res. 1993, accepted)

Chapter 7. Cisplatin and 5-Fluorouracil inhibit endothelial cell proliferation and interfere with endothelial cell procoagulant activity.

Chapter 8. General Discussion

Summary

Samenvatting

Afterwords 


\section{ABBREVIATIONS}

5FU

ATIII

BCE

BCS

BM

BrdU

BSA

CDDP

$\mathrm{CP}$

DAB

DCS

DMEM

ECM

EDTA

$\mathrm{H}_{2} \mathrm{O}_{2}$

$\mathrm{HgCl}_{2}$

HS

HUVEC

IODO

I.I

MC.

$\alpha$-MEM

$\mathrm{O}_{2}$ :

$\mathrm{OH}$.

PBS

PUFA

RVV

SEM

t-buOOH

TCM

TEM

TF
5-Fluorouracil

Anti-thrombin III

Bovine adrenal cortex capillary endothelial cells

Bovine calf serum

Basal membrane

5-bromo-2'-deox yuridine

Bovine serum albumin

cis-diamminedichloroplatinum (II) (Cisplatin)

Cancer procoagulant

3,3-Diaminobenzidin

Donor calf serum

Dulbecco's modified Eagles' minimal essential medium

Extra cellular matrix

Ethylenediaminetetraacetic acid

Hydrogenperoxide

Mercurychloride

Human serum

Human umbilical vein endothelial cells

Iodoacetamide

Labcling index

Mast cells

Minimal essential medium, alpha modification

Superoxide anion

Hydroxyl radical

Phosphate buffered saline

Polyunsaturated fatty acid

Russell's Viper Venom

Scanning electron microscopy

tert-butyl hydroperoxide

Tumor conditioned medium

Transmission electron microscopy

Tissue factor 


\section{Chapter 1.}

\section{Tumor angiogenesis: an introduction.}

Nos idées deviennent plus claires en passant sur nos lèvres C.P. Duclos (1704-1772)

\section{Introduction.}

Uncontrolled growth and invasion in cancer are not the only crucial conditions for the development and spread of a tumor. Tumor growth appears to remain limited until the onset of another crucial event: neovessel formation (Goldmann 1907" Folkman 1974a, 1974b, 1985ab, 1985c, 1990). This phenomenon is studied in the current work in order to obtain insight in the mechanisms that are involved in this event.

Before the onset of neovesse: formation, an avascular tumor nodule is presert. This phase only exists for a limited period of time (Folkman 1975), except when the tumor becomes dormant (Folkman et al. 1963). Thereafter tumor vessels develop. Without developmenit of vessels tumors are not likely to grow beyond $1.2 \mathrm{~mm}$ in diameter at the primary site in vivo (Folkman and Cotran 1976, Folkman 1990). From this perspective the important role for vascular endothelial cells in tumor growth became apparent.

In vitro studies on tumor angiogenesis: history.

Since the last century, morphologists have studied tumors and tumor-associated vascularization in a descriptive way (Ehrlich 1879, Virchow 1863, Goldman 1907). Then the transparant ear chamber technique was introduced (Clark and Clark, 1932,1939, Wood 1958) followed by the hamster cheek pouch (Warren and Shubik 1966, Greenblatt and Shubik 1968, Algire and Chalkey 1945). From these studies it was proposed that the ability to attract new bloodvessels from the host was a characteristic of tumor cells. It was not before the 1970s that Folkman and others provided evidence that one of the most important conditions in malignant tumor growth is the recruitment of blood vessels from the host vasculature. It was found that tumors produced diffusible factors in vivo that elicit capillary sprout formation from pre-existing vessels (Greenblatt and Shubik 1968, Folkman 1970, Folkman et al.1971a, Liotta 1985).

Experimental conditions such as the tumor spheroid model described by Sutherland (Sutherland et al.1971, Sutherland 1981, Sutherland et al.1986a, Sutherland 1986b, Sutherland 1988) or tumor growth in the isolated perfused organ (Gimbrone et al.1969) gave further insight in the behavior of the tumor in the early avascular phase, while other assays using the corneal micropocket (Gimbrone et al.1974), sustained-release polymer implants (Langer \& Folkman 1976), the chick embryo chorioallantoic membrane (CAM) (Ausprunk et al. 1974, Klagsbrun et al.1976) and cloned capillary endothelial cells were developed to create possibilities to study tumor-related angiogenesis (Folkman et al.1979). Especially in vitro assays using cultured microvascular endothelial cells growing either in a two- or three dimensional system accelerated the better understanding of the molecular and cellular mechanisms in the angiogenic process (Folkman and Haudenschild 1980, 
Montesano et al. 1985, Montesano 1992).

A number of terms have been proposed to describe the development of bloodvessels either from precursor cells, as takes place in early embryonic development, or by sprouting from pre-existing vessels. To prevent entanglement of definitions, in the current work the term "tumor angiogenesis" refers to the recuitment of vessels from the host vasculature by the tumor.

\section{Tumor vessel features.}

Tumor vessels are different from normal vessels in almost every respect. They have no innervation like normal vessels and the endothelial cells lining the vessel wall have a very high tumover compared to normal vessels (Rifkin et al.1982). The most striking difference however, is the increased permeability in tumor bloodvessels, which makes them so called "leaky" vessels (Senger et al.1983, 1986). Normally, endothelial cells are highly attenuated and line the luminal surface of the vasculature. They are multifunctional and perform several functions like providing the active and passive transport across the vascular wall and maintain the anti-thrombogenic surface of the cells (Jaffe 1985, Jaffe 1987, Cotran 1987, Fajardo 1989). Leakiness of the blood vessels is caused by several factors. One is the altered and strongly reduced basement membrane (BM) in tumor vessels.

The endothelial cell normally is attached to the basal lamina and contacts the underlying smooth muscle cells, mesangial cells and pericytes (Simionescu 1984, Orlidge \& d'A more 1987). The endothelial cell membrane is covered by glycosaminoglycans, glycoproteins and glycolipids and is attached through the basal lamina to the extracellular matrix (ECM) (Simionescu 1984). The BM and ECM are constructed of collagens (types I, III, IV and V), molecules like laminin and fibronectin and proteoglycans/glycosaminoglycans such as heparan sulfate, hyaluronic acid and chondroitin sulfate (Furcht 1986). It plays an important role in the responsiveness of the endothelial cell to stimuli (Furcht 1986).

The BM in tumor blood vessels is strongly diminished and a change in the synthesis of the glycosaminoglycans is found with elevated hyaluronic acid concentrations and the proteoglycans less sulfated (Ausprunk et al. 1981). These factors contribute to the increased leakiness of the tumor vessel.

Another explanation can be found in the origin of the tumor vasculature. Tumors are capable to produce mitogenic and/or angiogenic factors (Folkman and Klagsbrun 1987a) that induce the sprout formation in host vessels by endothelial cell activation. One of these factors is vascular permeability factor (VPF) (Senger et al.1986, Keck et al.1989) that may contribute to the leakiness of the newly formed vessels.

Finally, an additional contribution, this time lumen directed, to an altered flux over the tumor vessel wall has been postulated by Jain and collegues (Jain 1987, Vaupel \& Jain 1991, Boucher et al.1992). They describe that a high interstitial pressure in tumors which could be due to the absence of lymphatic vessels and the relatively fast expansion of tumor mass in a restricted space, causes a forced fluid exudation through the vasculature.

\section{Tumor angiogenesis: angiogenic factors.}

Tumor angiogenesis is generally described as a multistep process: endothelial cell activation, digestion of the extracellular matrix by collagenases and proteases, endothelial 
cell migration and proliferation, finally resulting in capillary formation (Paweletz and Knierim 1989, Bicknell and Harris 1991). The endothelial cells at the tip of the budding sprout do not proliferate; proliferation is restricted to the successive endothelial cells. Evidence: was given by Sholly (Sholly et al.1984) that capillaries still develop even when endothelial cells are devoid of the capability to proliferate due to irradiation. This indicates that proliferation is not an absolute requirement for capillary formation.

Considerable progress has been obtained during the last decades in the indentification of (tumor) angiogenic factors (TAF) (Folkman 1974b, 1986, 1987b). Angiogenesis stimulating, factors now contain both polypeptides and other factors. The latter ones are pcorly characterized but ample evidence has been given for a role of non-peptide factors like prostaglandines, nicotinamide and peroxides in angiogenesis (Form and Auerbach 1983, Kull et al. 1987, Szatrowski 1991). Other factors like heparin and copper obviously play a role in augmenting angiogenesis (Radju et al. 1984, Gullino et al.1990) bul the underlying mechanisms are still unknown.

The most extensively studied peptides in the context of angiogenesis are the Heparin Binding Growth Factors (HBGF) (Maciag et al.1984, Burgess \& Maciag 1989. Klagsbrun 1989, Goldfarb 1990). These factors display a high affinity for heparin (Gospodarowicz et al.1984, Klagsbrun 1989) and can induce an angiogenic response in the chorioallantoic chick embryo (CAM) model. Two members of this family are acidicand basic- Fibroblast Growth Factor (a-FGF and b-FGF) and at least five related forms have been described, among which several are products of oncogenes. The best described member is basic-Fibroblast Growth Factor (b-FGF). It is a cationic polypeptide and found in nearly all tissues. Related forms of FGF have been described with a higher molecular weight, but these forms are quite rare (Prats et al.1989). Acidic FGF (a-FGF), also known as Endothelial Cell Growth Factor (ECGF) has a similar molecular weight and $53 \%$ absolute sequence homology with b-FGF (Klagsbrun 1989). Acidic FGF, in contrast to basic FGF, is mainly found in neural tissues.

Acidic- and basic-FGF are cell associated proteins and their genetic code contains no information for a signal peptide (Vlodavsky et al.1987) which makes it difficult to explain how they act as angiogenic factors, since most angiogenic factors decribed are diffusable factors. Only Interleukin 1 shares the cell bound properties of FGF. When FGF exerts its activity it is mitogenic and chemotactic for endothelial cells in vitro and angiogenic in vivo (Klagsbrun et al.1976, Klagsbrun 1989, Klagsbrun \& d'Amore 1991). The related forms isolated from tumors are Int-2 (Dickson \& Peters 1987), Hst (Yoshida et al. 1988), K-fgf (Delli-Bovi et al.1987) and FGF-5 (Zhan et al.1988); they have 40-50\% homology with a- and b-FGF but they differ essentially from a- and b-FGF in that these forms do possess a signal peptide and are secreted (Rogelj et al.1988).

The group of Ferrara (Ferrara \& Henzel 1989, Leung et al.1989) isolated a heparin binding growth factor, vascular endothelial growth factor (VEGF), that is not related to either a-FGF or b-FGF, and is highly specific for endothelial cells. VEGF has been purified from conditioned medium from bovine pituitary follicullo stellate cells and from tumor cells (Gospodarowicz et al.1984, 1989, Levy et al.1989). VEGF binds to heparin and is mitogenic for capillary endothelial cells but not for other cell types and can elecit an angiogenic respons. It appears similar to Vascular Permeability Factor (VPF). VEGF 
has $24 \%$ homology with Platelet Derived Growth Factor (PDGF) which is a smooth muscle cell mitogen. Furthermore, VPF is a vascular permeability factor which causes fluid leakage (Connolly et al.1989) in bloodvessels. The mechanism of VPF in angiogenesis is not yet understood.

Transforming growth factor- $\alpha$ (TGF- $\alpha$ ) has been found in tumor cells and transformed fibroblasts, as well as in normal cells like macrophages (Imanishi et al.1989, Madtes et al. 1988). This growth factor acts via binding to the receptor for Epidermal growth factor (EGF) (Winkler et al.1989) and shows 40\% homology with this EGF (Marquat et al.1984). It stimulates endothelial cell growth and is angiogenic in vivo (Todaro et al. 1980). It has been suggested that TGF- $\alpha$ is an important mediator in inflammation and tumor vascularization (Klagsbrun 1991, Schrieber et al.1986).

Transforming Growth Factor B (TGF-B) is, despite its nomenclature not related to TGF$\alpha$. It was originally purified from tumors, but was subsequently found in a number of other tissues as well. TGF-B is generally produced in a non-active form, that can be activated by proteolysis or acidification (Lawrence et al.1984). It is a proliferation inhibitor in vitro for endothelial cells (Antonelli Orlidge et al.1989) but angiogenic in vivo. Since TGF- $\beta$ is an inhibitor for endothelial cell proliferation it is suggested that it promotes endothelial differentiation. Furthermore TGF- $B$ is chemotactic for monocytes, cells that are involved in inflammatory reactions including those around growing lumors (Wahl et al.1987). This may contribute to its angiogenic effect in vivo.

Platelet derived endothelial cell growth factor (PD-ECGF) does not share the heparinbinding properties of FGF. It is an intracellular peptide that is secreted by cells that synthesize this factor (i.e. platelets, foreskin fibroblasts, squamous carcinoma cells) (Miyazono et al.1987). PD-ECGF is structurally related to PDGF that stimulates fibroblast and smooth muscle cell proliferation (Ross 1989). PD-ECGF stimulates endothelial cell growth and is angiogenic in vivo.

Angiogenin and Angiotropin are examples of peptides that are angiogenic in vivo but not mitogenic in vitro. Angiogenin was first isolated from the adenocarcinoma cell line HT29 (Fett et al.1985). It was found not to stimulate endothelial cell proliferation or migration in vitro like other growth factors do, but to induce a strong angiogenic respons in the CAM assay. This suggests that angiogenin elecits its activity through other cell types. It is related to pancreatic RNAse $A$, but the latter does not have any angiogenic properties. Angiotropin is isolated from monocytes which play a role in wound healing. It is not mitogenic but it stimulates migration of endothelial cells in vitro and is angiogenic in vivo (Hockel et al.1987, 1988).

Tumor Necrosis Factor (TNF)- $\alpha$ also called cachectin is synthesized and secreted by tumor cells and activated macrophages (Beutler et al.1985, Beutler and Cerami 1986) and structurally related to lymphotoxin, which is also known as TNF-B (Gray et al.1984). TNF- $\alpha$ is multifunctional in immunity and inflammation and can cause necrosis in solid tumors (Beutler et al.1985). TNF- $\alpha$ can elicit a strong angiogenic respons in vivo and stimulate endothelial cell migratory behavior, but it inhibits endothelial cell proliferation in vitro (Leibovich et al.1987). TNF- $\alpha$ can induce the synthesis of GranulocyteMacrophage Colony Stimulating Factor (GM-CSF) and Interleukin 1 (II-1) by macrophages. Both factors can moderately stimulate endothelial cell proliferation and migration (Bussolino et al.1989). Although by this mechanism TNF- $\alpha$ can be an 
angiogenesis stimulator, it causes tumor regression when injected into the solid tumor. This contradiction can be explained by the delivery route of TNF- $\alpha$. When administered via the bloodstream to the interior of the tumor vessel, it causes coagulation, hemorrhage and necrosis of the tumor. However, when delivered at the exterior of the blood vessel as a result of synthesis by macrophages or tumor cells, it may induce endothelial cells to migrate and proliferate (Folkman and Ingber 1987c).

\section{Additional cell types involved in tumor angiogenesis: mast cells.}

In tumors, all circulating cells can be found. Lymphocytes, neutrophils, eosinophils, monocytes/macrophages, basophils and their resident counterparts mast cells, all have been detected in tumors (Blood \& Zetter 1990). Especially the latter two, macrophages and mast cells may play a potentiating role in tumor angiogenesis (Polverini \& Leibovich 1985, Roche 1985, 1986, Meininger \& Zetter 1992). Inflammation related macrophages may induce angiogenesis by generating angiogenic factors like angiotropin, TNF- $\alpha$, and b-FGF (Leibovich et al.1987, Baird et al.1985, Hockel et al.1988, Frater-Schroder el al. 1987, Südhoff \& Schneider 1992).

Mast cells are found in connective tissues in the proximity of blood vessels, and lymphatics (Tharp 1989). Increased numbers of mast cells are detected in hypersensitivity lesions, inflammatory tissue and in the vicinity of tumors, mostly in the surrounding connective tissues of the tumor and much less in the tumor parenchyma. It has long been thought mast cells participated in an inflammatory response to tumor cells as part of a host defense mechanism (Roche 1985, 1986). Evidence has been given that mast cells promote tumor growth (Dabbous et al.1991, Roche 1986) and play a role in angiogenesis (Azizkhan et al. 1980, Poole \& Zetter 1983, Starkey et al.1988).

The accumulation of mast cells in tumors is probably due to (still unknown) chemotactic factors secreted by tumors (Poole \& Zetter 1983). The role of mast cells once they have accumulated around the tumor, still remains to be elucidated. Folkman and co-workers described that heparin, released from mast cells stimulate endothelial cell migration (Azizkhan et al.1980) and when tested in the CAM assay, dramatically potentiated angiogenesis, although the heparin by itself was not angiogenic (Taylor \& Folkman 1982).

\section{Coagulation in tumor angiogenesis.}

Coagulation, platelet aggregation and fibrin formation are thought to play an important role in the growth and dissemination of cancer cells and in tumor angiogenesis (Bick 1992). In and around solid tumors fibrin deposits are found (Franks et al. 1976, Dvorak 1986, Freitas et al.1992). It has been suggested that these deposits promote tumor growth by providing a provisional matrix in which tumor cells can grow (Dvorak et al.1987) and to facilitate the development of a vascular network, i.e. angiogenesis (Folkman 1990). This fibrin matrix also protects the newly formed tumor nodule from the host-defense system (Donati \& Poggi 1980, Donati et al.1981).

Several mechanisms can account for fibrin formation. Mechanical cell damage could trigger fibrin formation via the extrinsic pathway of the coagulation cascade while inflammatory or immunogenic stimulation could initiate coagulation also via the intrinsic pathway. Furthermore it has been found that tumors can produce a procoagulant activity, 
called Cancer Procoagulant (CP). This CP is a cysteine protease, distinct from tissue factor (which is under normal conditions the most potent trigger of blood coagulation), factor VIIa or factor IXa which are serine proteases (Gordon et al. 1975, Falanga and Gordon 1985). C.P directly activates factor $\mathrm{X}$ to factor $\mathrm{Xa}$ in the coagulation cascade, independent of factor VII (Gordon 1987).

It is conceivable that the activation of endothelial cells during the process of lumor angiogenesis may play a role in the disturbance of the hemostatic balance in the host, since coagulation abnormalities have been found in cancer patients already in the last century (Andral \& Gavarret 1842, Trousseau 1885). These abnormalities, both thrombotic as well as hemorraghic not necessarily become clinically manifest but are mostly expressed at local levels, making it even more difficult to obtain insight in this phenomenon (Donati \& Poggi 1980, Donati et al.1981, Rickels \& Edwards 1983, Machovich 1987, Levine et al.1988, Bick 1992, Zacharski et al.1992, Monreal et
al.1991).

\section{Reactive oxygen species and tumor angiogenesis.}

In inflammatory reactions polymorphonuclear leukocytes, among others release oxygen free-radicals (Nathan 1987). These reactive oxygen species can cause cell injury by generating secondary oxygen metabolites like hydroxyl radicals $(\mathrm{OH} \cdot)$ superoxide anion $\left(\mathrm{O}_{2} \cdot\right)$ and hypochloric acid $(\mathrm{HOCl})$ and chloramines $\left(\mathrm{RNH}_{2} \mathrm{Cl}\right)$ able to attack nucleic acids, proteins and polyunsaturated fatty acids resulting in membrane to cell components by lipid peroxidation (Halliwel \& Gutteridge 1989, Hiraishi et al.1992, Harris et al. 1992). These oxidative processes are carefully safeguarded by detoxifying mechanisms like free radical scavengers, ion binding proteins, glutathione redox cycle, endogenous catalase (converting $\mathrm{H}_{2} \mathrm{O}_{2}$ to $\mathrm{H}_{2} \mathrm{O}$ and $\mathrm{O}_{2}$ ) or superoxide dismutase (converting $\mathrm{O}_{2} \cdot$ to $\mathrm{H}_{2} \mathrm{O}_{2}$ ) (Harlan et al.1984, Halliwell \& Gutteridge 1989, Hiraishi et al.1992). However, when endogenous antioxidant systems are exhausted, oxygen free radicals can induce cell
damage. Oxidative stress has been implicated in a wide range of diseases from rheumatoid arthritis to adult respiratory distress syndrome and atherosclerosis (reviewed in: Halliwell \&

Tumor cells generate large amounts of hydrogen peroxides (Szatrowski \& Nathan 1991, Voest et al.1992) and tumors often contain inflammatory cells including polymorphonuclear leucocytes. It is possible that endothelial cells in the surrounding of tumors are heavily subject to attack by reactive oxygen species and that this might play a role in the initiation or regulation of tumor angiogenesis. Especially endothelial cells are particularly sensitive to reactive oxygen species, since their membranes contain relatively high amount of polyunsaturated fatty acids (PUFAs). PUFAs are good targets for the reactive oxygen species. Furthermore, the endothelial cells have a relatively low catalase activity and high amounts of ferritin, which is an important iron source for lipid peroxidation (Dargel 1992).

\section{Inhibition of tumor angiogenesis.}

Cancer treatment consists of surgery, radiotherapy and systemic therapy with cytotoxic, and immunological manipulations. Although the target of these therapies traditionally is 
the tumor cell, the endothelial cell exposed in the tumor vasculature may be an attractive alternative target cell. It has been described that chemotherapeutic drugs have an inhibiting effect on endothelial cell proliferation and that endothelial cells seem to be more sensitive to chemotherapeutic drugs than for example fibroblasts (Hirata et al. 1989).

The failure of conventional chemotherapy to control the growth of most common human malignancies indicates however, that it is not effective as anti-angiogenic therapy in clinical practice. Apparently the chemotherapy is not capable to enter the tumor due to the high intertumoral pressure (Boucher et al.1992) or the endothelial cells are resistant, although this has not been properly studied. The endothelial cell remains an interesting target for chemotherapy if the drugs can be adequately administered or combined with modulation of resistance (Bicknell \& Harris 1991, Boucher et al. 1992)

Interaction between systemic therapy and vasculature may be benificial for tumor control, either directly or indirectly. Chemotherapeutic agents are associated with an enhanced endothelial cell reactivity to platelets (Bertomeu et al.1990) and other endothelial cell damage (Levine et al. 1988). This may be one of the mechanisms leading to an increased incidence of thromboembolic events in patients receiving chemotherapy (Levine et al. 1988, Bick 1992).

The vessel wall also appears to be a major site of reactivity in the case of treatment with interleukin-2. This immunomodulator increases the adhesiveness of leukocytes to the endothelial cells and lead to increased vascular permeability (Ohkubo et al.1991). The extent of the contribution of drug-endothelial cell interactions to the toxicity of systemic therapy and the mechanisms thereof are presently largely unknown.

Another approach in the struggle against neoplastic growth is the search for angiogenesis inhibitors (Folkman et al.1971b, 1972, 1983, 1985a, 1985b, Gross et al.1981). In the past decade, several of these factors were identified. They are briefly summarized here. Taylor and Folkman (Taylor \& Folkman 1982, Folkman and Ingber 1989) were the first to describe blocking of heparin-stimulated vessel growth in the CAM model by protamine. Their studies resulted in the surprising finding that a combination of heparin with cortisone had an angiostatic effect (Crum et al.1985). Other factors like the already mentioned peptides TNF- $\alpha$ and TGF- $B$ are inhibitors of endothelial cell proliferation. However, they can induce an angiogenic response which emphasizes again that a proliferative response and an angiogenic response of endothelial cells are not identical phenomena. Platelet Factor IV (Taylor\& Folkman 1982, Sharp et al.1990), Interferongamma (Friesel et al.1987), Interferon-alpha-2a (White et al.1989) and a cartilage-derived factor (Brem and Folkman 1975, Moses et al.1990) are also found to inhibit tumor growth in some models by interference with angiogenesis. Recently Folkman and his coworkers have identified Fumagillin (Ingber et al.1990) which inhibits tumor angiogenesis and suppresses tumor growth in a wide variety of tumors.

The last group of angiogenesis inhibitors consist of the products of angiogenesis suppressor genes. Normal active suppressor genes are thought to play a role in growth control, and therefore some may be thought to inhibit unregulated endothelial proliferation. Rastinejad found that an angiogenesis inhibitor in conditioned medium from a hamster/hamster-human hybrid was the product of a cancer suppressor gene (Rastinejad et al.1989). This inhibitor was identified as Thrombospondin (Good et al.1990). 
Furthermore, the retinoblastoma-1 suppressor gene was found to suppress the angiogenic phenotypc of osteosarcoma cells (Tolsma et al.1991).

Finally it has to be stressed that virtually all results on angiogensis inhibition were obtained in in vitro and animal studies. In vivo human studies will be needed to determine their inhibitory effects on in situ tumors.

\section{Scope of the study.}

The general objective of the work described here was to establish a model system to study the angiogenic properties of human colorectal tumor cell lines in order to obtain insight in the mechanisms of tumor angiogenesis. It was hypothesized this would establish a basis for the development and testing of future anti-angiogenic interventions in the treatment of malignant growth.

\section{Outline of the study.}

The objective of this work was to study the interaction between tumor cells and vascular endothelial cells. Since tumor angiogenesis can be classified roughly into the three main features, endothelial cell proliferation, migration and activation in response to tumor cells, we started with the development of an in vitro proliferation assay for endothelial cells exposed to tumor cells. We compared the effect on endothelial proliferative behavior of tumor cells cultured in a monolayer to that of tumor cells cultured as avascular spheroids (Sutherland 1981, 1988). Then we studied the migratory behavior of endothelial cells when exposed to tumor spheroids in a matrix model (Montesano 1992).

Subsequently the procoagulant response of endothelial cells upon activation by the tumor cells was evaluated by measuring coagulation factor $\mathrm{X} / \mathrm{Xa}$ activity. Considering that products of reactive oxygen species is a propenty shared by many tumors, we investigated if reactive oxygen species may be involved in the activation of endothelial cells (Dargel 1992) by tumor cells. Therefore we investigated the effect of the addition of peroxides to our experimental system.

Since it has been described that mast cells are important accessory cells in tumor angiogenesis (Roche 1985,1986, Blood and Zetter 1990, Folkman and Shing 1992) we also added mast cells to our experimental system and evaluated their effect on the proliferation and (procoagulant) activation of endothelial cells.

Finally, we tested the effect of two chemotherapeutic agents on the proliferative capacity, survival and procoagulant response of endothelial cells.

\section{References.}

Algire GH, Chalkey HW. Vascular reactions of normal and malignant tissues in vivo. I. Vascular reactions of mice to wounds and to normal and neoplastic transplants. J.Natl.Cancer Inst.6;73-85, 1945

Andral et Gavarret. Recherches sur les modifications de proportion de quelques principe du sang: fibrine. globules, matériaux solides du sérum et eau dans les maladies. Paris, Fortin, Masson et C' $C^{2}$ libraires
225-239, 1842.

Antonelli Orlidgo A, Suunders KB, Smith SR, D'Amore PA. Activated form of transforming growth factorbela is produced by cocultures of endothelial cells and pericyles. Proc. Nat.Acad.Sci.U.S.A. 86, 4544-4548,
1989 . 
Ausprunk DH, Boudreau $\mathrm{CL}$, and Nelson DA. Proteoglycans in the microvasculature. 1. Histochemical localization in microvessels of the rabbit eye. Am.J.Pathol. 103, 353-375, 1981.

Ausprunk DH, Knighton DR, Folkman J. Differentiation of vascular endothelium in the chick chorioallantois: a structural and autoradiographic study. Dev. Biol. 38, 237, 1974.

Azizkhan RG, Azizkhan CJ, Zetter BR, Folkman I. Mast cell heparin stimulates migration of capillary endothelial cells in vitro. J. Exp. Med. 152, 931-944, 1980.

Baird A, Mormede P. Bohlen P. Immunoreactive fibroblast growth fuctor in cells of peritoneal exudate suggest its identity with macrophage derived growth factor. Biochem. Biophys. Res. Comm. 126, 358-364. 1985.

Bertomeu MC, Gallo S, Lauri D, Levine MN, OTr FW, Buchanan MR. Chemotherapy enhances endothelial cell reactivity to platelets. Clin. Exp. Metastasis. Vol.8 (6), 511-518, 1990.

Beutler B, Mahoney J, Le Trang N, Pekula P, Cerami A. Purification of cachectin, a lipoprotein lipasesuppressing hormone secreted by endotoxin-induced RAW 264.7 cells. J.Exp.Med. 161 (5), 984-995, 1985.

Beutler B, Cerami A. Cachectin and tumour necrosis factor as two sides of the same biological coin. Nature $320,584-588,1986$.

Bick RL. Coagulation abnormalities in malignancy: a review. Sem. Thromb. Hemostas. 18,4, 353-379, 1992.

Bicknell R, Harris AL. Novel growth regulatory factors and tumour angiogenesis. Eur.J.Cancer Vol.27 (6), 785-789, 1991.

Blood $\mathrm{CH}$, Zetter BR. Tumor interactions with the vasculature: angiogenesis and tumor metastases. Biochem. Biophys. Acta 1032, 89-118, 1990.

Boucher Y, Jain RK. Microvascular pressure is the principal driving force for interstitial hypentension in solid tumors: implications for vascular collapse. Cancer Res 52 (18), 5110-5114, 1992.

Brem H, Folkman J. Inhibition of tumor angiogenesis mediated by cartilage. J.Exp.Med. 141, 427-439, 1975

Burgess WH, Maciag T. The heparin binding (fibroblast) growth factor family of proteins. Ann Rev Biochem 58, 575-606, 1989.

Bussolino F, Wang JM, Defelipi P. Granulocyte and granulocyte-macrophage colony stimulating factors induce human endothelial cells to migrate and proliferate. Nature, 337, 471-473, 1989.

Clark ER and Clark EL. Observations on the new growth of lymfatic vessels as seen in transparant chambers introduced into the rabbits ear. Am.J.Anat. 51,43:441-447, 1932

Clark ER and Clark EL. Microscopic observations on the growth of blood capillaries in the living animal. Am.J.Anat. 60, 251, 1939.

Connolly DT, Heuvelman DM, Nelson R, Olander JV, Eppley BL. Tumor vascular permeability factor stimulates endothelial cell growth and angiogenesis. J. Clin. Invest. 84 (5), 1470-1478, 1989. 
Cotran RS. New roles for the endothelium in inflammation and immunity. Am J Pathol 129, 407, 1987.

Crum R, Szabo S, and Folkman J. A new class of steroids inhibits angiogenesis in the presence of heparin or a heparin fragment. Science 230, 1375-1378, 1985.

Dabbous MKh, Haney L. Nicolson GL, Eckley D, Woolley DE. Mast cell modulation of tumour cell proliferation in rat mammary adenocarcinomai 13762NF. Br.J.Cancer 63,873-878, 1991.

Dargel R. Lipid peroxidation - a common pathogenic mechanism? Exp. Toxic Pathol. 44, 169-181, 1992.

Delli-Bovi P, Curatola AM, Kem FG, Greco A, Ittman M, Basilico C. An oncogene isolated by Iransfection of Kaposi's sarcoma DNA encodes a growth factor that is a member of the fibroblast growth factor fumily. Cell 50, 729-737, 1987.

Dickson C, Peters G. Potential oncogene product related to growth factors. Nature 326, 833, 1987.

Donati MB, Poggi A. Malignancy and hemostasis. Br. J. Haematol. 44, 173, 1980.

Donati MB, Poggi A, Semeraro N. Congulation in malignancy. In: recent advances in blood coagulation. Poller L. Editor. Churchill Livingstone, New York 1981, 375-391.

Dvorak HF. Tumors: wounds that do not heal. New Eng. J. Med. 315, 1650-1659, 1986.

Dvorak HF, Harvey VS, Estrella P, Brown LF, McDonagh J, Dvorak AM. Fibrin containing gels induce angiogenesis. Implications for tumor stroma generation and wound healing. Lab. Invest. 57, 673-686, 1987.

Ehrlich P. Beitrage zur Kenntniss der granulierten Bindegewebzellen und der easinophilen leucocyten. Arch. Anat. Physiol. 3, 166-169, 1879.

Fijardo LF. The complexity of endothelial cells. A review. A.J.C.P. Vol.9(2), 241-250, 1989.

Falanga A, Gordon S: Isolation and characterization of cancer procoagulant: a cysteine proteinase from malignant tissue. Biochemistry 1985, 24: 5558-5567

Ferfara N, Henzel WJ. Pituitary follicular cells secrete a novel heparin-binding growth factor specific for vascular endothelial cells. Biochem. Biophys. Res. Commun. 161, 851-858, 1989.

Fett JW, Strydom DJ, Lobb RF, Alderman EM, Betheme JL et al. Isolation and characterization of angiogenin an angiogenic protein from human carcinoma cells. Biochem. 24, 5480-5486, 1985.

Folkman J, Long DM, Becker FF. Growth and metastasis of tumor in organ culture. Cancer 16, 453, 1963.

Folkman J. In: "Carcinoma of the colon and antecedent epithelium" W.J. Burdette ed.) Chapter 6. Thomas, Springfield, Illinois, 1970

Folkman J, Merler E, Abernathy C, Williams G. Isolation of a tumor factor responsible for angiogenesis. J.Exp. Med. 133, 275, 1971 .

Folkman J. Tumor angiogenesis: therapeutic implications. New Engl.J.Med. 285, 1182-1186, 1971b.

Folkman J. Anti-angiogenesis: new concept for therapy of solid tumors. Ann. Surg. 175, 409, 1972. 
Folkman J. Tumor angiogenesis. Adv. Cancer Res. 19, 331, 1974a.

Folkman J. Proceedings: tumor angiogenesis factor. Cancer Res.34, 2109, $1974 \mathrm{~b}$.

Folkman J. Tumor angiogensis. In Cancer 3, Biology of tumors: Cellular Biology and Growth, Becker FF. Ed. Plenum Press, New York. Chapter 13, 1975.

Folkman J. and Cotran R. Relation of vascular proliferation to tumor growth. Int. Rsy. Exp. Pathol. 16, 207. 1976.

Folkman J. Haudenschild C, Zetter B. Long-term culture of capiliary endothelial cells. Proc.Natl.Acad.Sci.U.S.A. 76, 5217, 1979.

Folkman J, Haudenschild C. Angiogenesis in vitro. Nature 288, 551, 1980.

Folkman J, Langer R, Lindhardt RJ. Haudenschild C, Taylor S. Angiogenesis inhibition and rumor regression caused by heparin or a heparin fragment in the presence of cortisone. Science 221, 719-725. 1983.

Folkman J. Tumor angiogenesis. Adv.Cancer Res. Vol.43, 175-203, 1985a.

Folkman J. Regulation of angiogenesis: a new function of heparin. Biochem. Pharmacol. 34, 905., 1985b.

Folkman J. Angiogenesis and its inhibitors. In: Important advances in oncology, Da Vita, V.T. Jr. Hellmann S, Rosenberg SA, Editors. Lippincott, Philedelphia, 42, 1985c.

Folkman J. How is blood vessel growth regulated in normal and neoplastic tissue? G.H.A. Clowes memorial award lecture. Cancer Res. 46, 467, 1986.

Folkman J, Klagsbrun M. Angiogenic factors. Science 235, 442-447, 1987a.

Folkman J, Klagsbrun M. A family of angiogenic peptides. Nature 329, 442-447, $1987 \mathrm{~b}$.

Folkman J, Ingber DE. Inhibitors of angiogenesis: angiostatic steroids. In: Angiogenesis - Mechanisms and Pathobioligy. Editors Rifkin DB and Klagsbrun M. Cold Spring Harbor Laboratory, Cold Spring Harbor NY, 95, 1987c.

Folkman J, Ingber DE. Angiostatic steroids. In: Anti-inflammatory steroid action: basic and clinical aspects. Schleimer RP, Claman HN, Oronsky AL, editors. New York, Academic Press, Chapter 14, 330$350,1989$.

Folkman J. What is the evidence that tumors are angiogenesis dependent? J.Natl.Cancer Institute Vol.82. No. 1;4-6,1990.

Folkman J, Shing Y. Angiogenesis. Minireview J. Biol. Chem. 267,16, 10931-10934, 1992.

Form DM, Auerbach R. PGE 2 and angiogenesis. Proc. Soc. Exp. Biol. Med. 172, 214, 1983.

Franks JJ, Gordon SG, Kao B, Sullivan T, Kirch D. Increased fibrin formation with tumors and its genesis. In: Plasma protein tumover, Bianchi R, Mariani G and McFarlane AS, editors. Macmillan, New York; $423,1976$. 
Prater-Schroder MF, Risau W, Hallmann R, Gautschi P, Bohlen P. Tumor necrosis factor alpha, a potent inhibitor of endothelial cell growth in vitro, is angiogenic in vivo. Proc. Natl.Acad.Sci.USA 84 (15), 5277$5281,1987$.

Freitas I, Baronzio GF, Bami S, Bertone V, Griffini P, Accossato P, Pontiggia P. Tumor angiogenesis: evidence of new blood channels from plasm infiltrations. EXS. 61, 81-84, 1992.

Friesel R, Komoriya A, Maciag T. Inhibition of endothelial cell proliferation by gamma-interferon. J. Cell Biol. 104. 689-696, 1987.

Furcht LT. Critical factors controlling angiogenesis: cell products, cell matrix and growth factors. Lab Invest 55 (5), 505-509, 1986.

Gimbrone MA, Aster RH, Cotran Rs, Corkery J, Jandl J, Folkman J. Preservation of vascular integrity in organs! perfused in vitro with a platelet-rich medium. Nature 222, 33-36, 1969.

Gimbrone MA, Cotran RS, Leapman SB, Folkman J. Tumor growth and neovascularization: an experimental model using the rabbit comea. J.Natl.Cancier Inst. 52, 413, 1974.

Goldmann E. Growth of the malignant disease in man and the lower animals with special reference to vasculair system. Proc. R. Soc. Med. 1, 1, 1907.

Goldfarb M. The fibroblast growth factor fumily. Cell Growth and Differentiation. I, 439-445, 1990.

Good DJ, Polverini PJ, Rastinejad F, Le Beau MM, Lemons RS, Frazier WA, Bouck NP. A tumor suppressor-independent inhibitor of angiogenesis is immunologically and functionally indistinguisable from a frugment of thrombospondin. Proc. Natl. Acad, Sci. USA 87 (17), 6624-6628, 1990

Gordon SG, Franks JJ, Lowis B. Cancer procoagulant A: a factor $X$ activating procoagulant from malignant tissue. Thromb. Res. 6, 127, 1975.

Gordon SG. Cancer Procoagulant. In: Hemostasis and Cancer. Laszlo Muszbek Editor, CRC Press Inc. Boca Raton, Florida; 4-14, 1987

Gospodarowicz. D. Cheng J, Lui GM, Baird A, Bohlen P. Isolation of brain fibroblast growth factor by heparin-Sepharose affinity chromatography: identity with pituitary fibroblast growth factor. Proc. Natl. Acad. Sei. USA. 81, 8963-8967, 1984.

Gospodarowicz D, Abraham JA, Schilling J. Isolation and characterization of a vascular endothelial cell mitogen produced by pituitary-derived folliculo stellate cells. Proc.Natl.Acad.Sci. USA 86, 7311-7315, 1989.

Gray PW, Aggarwal BB, Benten CV, Bringman TS. Henzel WJ. Cloning and expression of cDNA for human lymphotoxin, lymphokine with tumor necrosis activity. Nature 320, 584-588, 1984.

Greenblatt M. Shubik P. Tumor angiogenesis: transfilter diffusion studies in the hamster by the transparant chamber technique. J.Natl.Cancer Inst.41: 111-124, 1968

Gross J, Azizkhan RG, Biswas C, Bruns R, Hsieh D, Folkman J. Inhibition of tumor growth, vascularization and collagenolysis in the rabbit comea by medroxyprogesterone. Proc.Natl.Aced.Sci. U.S.A. $78,1176-1180,1981$ 
Gullino PM, Ziche M. Alessandri G. Gangliosides, copper ions and angiogenic capacity of adult tissues. Cancer and Metastasis Reviews. 9, 239-251, 1990.

Halliweli B, Gutteridge JMC. Free radicals in biology and medicine. B. Halliwell and Gutteridge JMC eds. 2nd. edition, Oxford University Press, Oxford 1989.

Harlan JM, Levine JD, Cullahan KS, Schwartz BR. Glutathione redox cycle protects cultured endothelial cells against lysis by extracellularly generated hydrogen peroxide. J. Clin. Invest. 73, 706-713, 1984.

Harris M, Schiller H, Reilly P, Donowitz M, Grisham M, Bulkley G. Free radicals and other reactive oxygen metabolites in inflammatory bowel disease: cause, consequence or epiphenomenon? Pharm. Ther. 53. 375-408, 1992.

Hiraishi H, Terano A, Razandi M, Sugimoto T, Haradu T, Ivey K. Role of cellular superoxide dismutase against reactive oxygen metabolite injury in cultured bovine aortic endothelial cells. J. Biol. Chem. 267, 21, 14812-14817, 1992 .

Hirata S, Matsubarn T, Saura R, Tateishi H, Hirohata K. Inhibition of in vitro vascular endotheilial cell proliferation and in vivo neovascularization by low-dose methotrexate. Arth. Rheumat. 32,9, 1065-1073, 1989.

Hockel M, Sasse J, Wissler JH. Purified monocyte-derived angiogenic substance (angiotropin) stimulates migration, phenotypic changes, and "tube formation" but not proliferation of capillary endothelial cells in vitro. J. Cell Physiol. 133 (1), 1-13, 1987.

Hockel M, Jung W, Vaupel P, Rabes H, Khaledpour C, Wissler JH. Purified monocyte-derived angiogenic substance (angiotropin) induces controlled angiogenesis associated with regulated tissue proliferation in rabbit skin. J.Clin. Invest. 82 (3), 1075-1090, 1988.

Imanishi K, Yamaguchi K, Suzuki M, Honda S, Yanaihara N, Abe K. Production of transforming growth factor-alpha in human tumour cell lines. Br.J.Cancer 59 (5), 761-765, 1989.

Ingber D, Fujita T, Kishimoto S, Sudo K, Kanamaru T, Brem H, Folkman J. Synthetic analogues of fumagillin that inhibit angiogenesis and suppress tumour growth. Nature 348, No.6301, 555-557, 1990.

Jaffe EA. Physiologic functions of normal endothelial cells. Ann. N.Y.Acad. Sci. 454, 279-291, 1985.

Jaffe EA. Cell biology of the endothelial cells. Hum Pathol 18, 2341987.

Jain RK. Transport of molecules in the tumor interstitium, a review. Cancer Res. 47, 3038-3050, 1987.

Keck PJ, Hauser SD, Krivi G, Sanzo K, Warren T, Feder J, Connolly DT. Vascular permeability factor, an endothelial cell mitogen related to PDGF. Science 246, 4935, 1309-1312, 1989.

Klagsbrun M. The fibroblast growth factor family: structural and biological properties. Progress in Growth Factor Research Vol.1 207-235,1989.

Klagsbrun M, D'Amore PA. Regulators of angiogenesis. Ann Rev Physiol, 53 217-239, 1991.

Klagsbrun M, Knighton D, Folkman J. Tumor angiogenesis activity in cells grown in tissue culture. Cancer Res.36, 110, 1976. 
Kull FC, Brent DA, Parikh I, Cuatracasas P. Chemical identification of a tumor-derived angiogenic factor. Science 236 (4803), 843-845, 1987.

Langer R, Folkman J. Polymers for the sustained release of proteins and other macromolecules. Nature $263,797-800,1976$

Lawrence DA, Pircher R, Kryceve-Martinerie C, Julien P. Normal embryo fibroblasts relesse transforming growth factor in a latent form. J.Cell.Physiol. 121 (1), 184-188, 1984.

Leibovich SJ, Polverini PJ Shepard HM, Wiseman DM, Shively V, Nuseir N. Macrophage induced angiogenesis is mediated by tumor necrosis factor alpha. Nature 329, 630-632, 1987.

Leung DW, Cachianes G, Kuang WJ, Goeddel OV, Ferrara N. Vascular endothelial growth factor is a secreted angiogenic mitogen. Science 246, 1306-1309, 1989.

Levine MN, Gent M, Hirsch J, Amold J, Goodyear MD, Hryniuk W, DePauw S. The thrombogenic effect of anticancer drug therapy in women with stage II breast cancer. New Eng. J. Med. 318, 404-407, 1988.

Levy AP. Tamarco R, Brem H, Nathans D. An endothelial cell growth factor from the mouse neuroblastoma cell line NB41. Growth Factors 2 (1), 9-19, 1989.

Liotta LA. Isolation of a protein that stimulates blood vessel growth. Nature 318, 14, 1985.

Machovich R. Role of blood coagulation-fibrinolytic system and endothelial cells in malignancy, In: Hemostasis and cancer. L. Muszbek Editor, CRC Press boca Raton, Florida, 53-64, 1987.

Maciag T, Mehlman T, Friesel R, Schrieber A. Heparin binds endothelial cell growth factor, the principal mitogen in the bovine brain. Science $225,932-935,1984$.

Madtes DK, Raines EW, Sakariassen KS, Assoian RK, Sporn MB. Induction of transforming growth factor $\alpha$ in activated human alveolar macrophages. Cell 53, 285-293, 1988.

Marquadt H, Hunkapillar MW, Hood LE, Todaro GJ. Rat transforming growth factor type I: structure and relation to epidermal growth factor. Sience 223, 1079, 1984.

Meininger CJ. Zetter BR. Mast cells and angiogenesis. Sem. Cancer Biol. 3(2), 73-79, 1992.

Miyazona K, Okabe T, Urabe A. Takaku F, Heldin CH. Purification and properties of an endothelial cell growth factoi from humen platelets. J Biol Chem 262, 4098-4103, 1987.

Montesano R, Orci L. Tumor-promoting phorbol ester induce angiogenesis in vitro. Cell 42, 469-477, 1985.

Montesano R. Rogulation of angiogenesis in vitro. Eur.J.Clin.Invest. 22, 504-515, 1992

Monreal M. Lafoz E. Casals A, Inaraja L, Montserrat E, Ma Callejas J, Martorell A. Occult cancer in patients with deep venous thrombosis: systematic approach. Cancer 67, 541-545, 1991 .

Moses MA. Sudhalter J, Langer R. Indentification of an inhibitor of neovaccularization from cartilage. Science 248, 1408-1410, 1990.

Nathan CF. Neutrofil wctivution on biological surfaces. J. Clin. Invest. 80, 1550-1560, 1987. 
Ohkubo C, Bigos D, Jain RK. Interleukin 2 induced leukocyte adhesion to the normal and tumor microvasculature in vivo and its inhibition by dextran sulfate: implications for vascular lenk syndrome. Cancer Res. 51(5) 1561-1563, 1991.

Orlidge A, and D'Amore PA. Inhibition of the capillary endothelial cell growih by pericytes and smooth muscle cells. J.Cell Biol.105, 1455-1462, 1987.

Paweletz N. and Knierim M. in: Tumor related angiogenesis. Critical Reviews in Oncology and Haematology Vol.9,3, 197-242, 1989.

Polverini PJ, Leibovich SJ. Induction of neovascularization and non-lymphoid mesenchymal cell proliferation by macrophage cell lines. J.Leukocyte Biol. 37 (3), 279-288, 1985.

Poole TJ and Zetter BR. Stimulation of rat peritoneal mast cell migration by tumor-derived peptides. Cancer Res. 43 (12 Pt. 1), 5857-5861, 1983.

Prats H, Kaghad M, Prats AC, Klagsbrun M, Lelias JM. High molecular mass forms of basic firoblast growvth factor are initiated by alternative CUG codons. Proc Natl Acad Sci USA 86, 1836-1840, 1989

Radju KS, Alessandri G, Gullino P. Characterization of a chemoattractant for endothelium induced by angiogenesis effectors. Cancer Res. 44, 1579, 1984.

Rastinejad F, Polverini PF, Bouck NP. Regulation of the activity of a new inhibitor of angiogenesis by a cancer suppressor gene. Cell 56, 345-355, 1989.

Rickles FR, Edwards RL. Activation of blood coagulation in patients with cancer: Trousseau's syndrome revisited. Blood 62, 14-31, 1983.

Rifkin DB, Gross JL, Moscatelli D. In: Pathobiology of the endothelial cell. H.L. Nússel and H.J. Vogels, eds. pp. 191-197. Academic Press, New York 1982.

Roche WR. Mast cells and tumors; the specific enhancement of tumor proliferation in vitro. Am.J.Pathol. 119 (1), 57-64, 1985.

Roche WR. The nature and significance of tumour-associated mast cells. J.Pathol.48, 175-182, 1986.

Rogelj S, Weinberg RA, Fanning P. Klagsbrun M. Basic fibroblast growth factor fused to a signal peptide transforms cells. Nature 331, 173-175, 1988.

Ross R. Platelet derived growtb factor. Lancet 1, 1179-1182, 1989.

Schrieber AB, Winkler ME, Dernyck R. Transforming growth factor $\alpha$ : a more potent angiogenic mediator than epidermal growth factor. Science 232, 1250-1253, 1986.

Senger DR, Galli SJ, Dvorak AM, Perruzzi CA, Harvey VS, Dvorak HF. Tumor cells secrete a vascular permeability factor that promotes accumulation of ascites fluid. Science 219, 983-985, 1983.

Senger DR, Perruzzi CA, Feder J, Dvorak HF. A highly conserved vascular permeability factor secreted by a variety human and rodent tumor cell lines. Cancer Res. 46, 5629-5632, 1986.

Sharp RJ, Byers HR, Scott CF, Bauer SI, Maione TA. Growth inhibition of murine melanoma and human colon carcinoma by recombinant platelet factor IV. J. Natl. Cancer Inst. 82, 848, 1990. 
Sholly MM, Ferguson GP, Seibel HR, Montour JL, Wilson JK. Mechanisms of neovascularization. Vascular sprouting can occur without proliferation of endothelial cells. Lab. Invest. 51, 624-632, 1984.

Simionescu M, Siminonescu N. Ultrastructure of the microvascular wall: Functional correlations. In: Handbook of Physiology section 2, Vol.4:41. Eds. Renkin EM, Michell CC. 1984.

Starkey JR, Crowle PK, Taubenberger S. Mast-cell deficient $w / w^{\nu}$ mice exhibit a decreased rate of tumor angiogenesis. Int.J.Cancer 42, 48-52, 1988.

Südhoff T, Schneider W. Fibrinolytic mechanisms in tumor growth and spreading. Clin.Invest. 70, 631. 636, 1992.

Sutherland RM, McCredie JA, Inch WR. Growth of multicell spheroids in tissue culture as a model of nodular carcinomas. J. Natl.Cancer Inst. 46, 113-120, 1971.

Sutherland R. Spheroids in cancer research. Cancer Res.41, 2980-2984, 1981.

Sutherland RM, Sordat B, Bamat J, Gabbert H, Bourrat B, Mueller-Klieser W. Oxygenation and differentiation in multicellular spheroids of human colon carcinoma. Cancer Res. 46, 5320-5329, 1986a

Sutherland RM. Importance of critical metabolites and cellular interactions in the biology of microregions of tumors. Cancer 58, 1668-1680, 1986b.

Sutherland RM. Cell and environment interactions in tumor microregions: the multicell spheroid model. Science 240, 177-184, 1988.

Szatrowski TP, Nathan CF: Production of large amounts of hydrogen peroxides by human tumor cells. Cancer Res 1991, 51: 794-798

Taylor S, Folkman J. Protamine is an inhibitor of angiogenesis. Nature 297,307-312, 1982.

Tharp MD. The interaction between mast cells and endothelial cells. J.Invest.Dermatol. Vol.93 (2), Suppl. 107S-112S, 1989.

Todaro GJ, Fryling C, DeLarco JE. Transforming growth factors produced by certain human tumor cells: polypeptides that interact with epidermal growth factor receptors.Proc Natl Acad Sci USA 77, 5258-5262, 1980.

Tolsma SS, Fung YK, Huang GS, Polverini PJ, Bouck N. RB-1 expression abrogates the angiogenic phenotype of osteosarcoma cells. Proc. Annu. Meet. Am. Assoc. Cencer Res. 32, A337, 1991

Trousseau A. Phlegmatia alba dolens. Clinique médicale de L'Hotel-dieu de Paris. Librairie J.B. Baillière et fils. septieme edition, 695-705, 1885.

Vaupel P, Jain RK. Tumor blood flow and metabolic micnoenvironment: characterization and therapeutic implications. Fisher Publishers, Stuttgart, Germany 1991.

Virchow R. " Die Krankenhaften Geschwìlste". August Hirschwald, Berlin 1863, cited by Paweletz N. and Knierim M. in: Tumor related angiogenesis. Critical Reviews in Oncology and Haematology Vol.9,3, 197$242,1989$. 
Vlodavsky I. Fridman R, Sullivan R, Sasse J, Klagsbrun M. Aortic endotheliall cells synthesize basic fibroblast growth factor which remains cell associated and platelet-derived growth factor-like protein which is secreted. J Cell Physiol 131, 402-408, 1987.

Voest E, Van Faassen E, Van Asbeck B, Neij! J, Marx J. Increased hydrogen peroxide concentration in human tumor cells due to nitroxide free radical. Biochem. Biophys. Acta 1136, I13-118, 1992.

Wahl SM, McCartney-Francis, Mergenhagen SE. Inflammutory and immunomodulatory roles of TGF-beta. Immunol. Today $10(8): 258,1987$.

Warren BA, Shubik P. The growth of the blood supply to melanoma Iransplants in the hamster cheek pouch. Lab.Invest. 15:464,1966.

White CW, Sondheimer HM, Crouch EC, Wilson H, Fan LL. Treatment of pulmonary hemangiomatosis. with recombinant Interfercm-alpha-2a. New Eng.J.Med. 320(18), 1197-1200, 1989.

Winkler ME, O'Connor L, Winget M, Fendly B. Epidermal growth factor and transforming grovih factor alpha bind differently to the epidermal growth factor receptor. Biochem. 28 (15), 6373-6378, 1989.

Wood S. Pathogenesis of metastasis formation observed in vivo in the rabbit ear chamber. Arch. Pathol. 66: $550,1958$.

Yoshida T, Muramatsu H, Muramatsu T, Sukamoto H, Katoh $O$. Differential expression of rwo homologous and clustered oncogenes, Hst-1 and Int-2 during differentiation. Biochem Biophys Res Coinmun 157, 618. 625, 1988.

Zacharski LR, Wojtukiewicz MZ, Costantini V, Ornstein DL, Memoli VA. Pathways of coagulution/fibrinolysis activation in malignancy. Sem. Thromb. Hemostas. Vol.18, No.1, 104-116, 1992.

Zhan X, Bates B, Hu XG, Golfarb $M$. The human FGF-5 oncogene encodes a novel protein related to fibroblast growth factors. Mol Cell Biol 8, 3487-3495, 1988. 



\title{
Chapter 2.
}

\section{Development of an in vitro proliferation assay.}

\author{
Based on "Lichtenbeld HC, Blijham $\mathbf{G H}$. Tumor cell spheroids induce a mitogenic \\ response in endothelial cells. Angiogenesis: Key principles, Science, Technology, \\ Medicine. R. Sieiner, PB Weisz and R. Langer, Eds. Birkhäuser Verlag Basel, 261-265, \\ 1992."
}

\begin{abstract}
.
Conditioned media from spheroids of human colorectal tumor cell lines HT29, SW620, SW480 and $\mathrm{CaCo} 2$ were tested for their mitogenic activity on human umbilical vein endothellal (HUVE) and bovine capillary endothelial (BCE) cells. Tumor cells were cultured either as monolayers of as spheroids. All tumor spheroid-conditioned media were capable to increase the labeling indices in both endothelial cell population. However, tumor spheroid conditioned medium exceeded the mitogenic activity of tumor monolayer conditioned medium. Mitogenic activity decreased in the following order: SW620, HT29/SW480 and CaCo2. The endothelial cell mitogenic activity of the spheroids seemed not to be dependent on the presence of necrosis nor on their in vivo cytokinetic characteristics.
\end{abstract}

\section{Introduction.}

Angiogenesis can roughly be classified into three main aspects; proliferation, migration and differentiation of endothelial cells induced by tumors. Since the objective of this study is the establishment of an in vitro model to study tumor angiogenesis, in this work the colorectal tumor cell lines HT29, SW480, SW620 and $\mathrm{CaCo} 2$ are used. These tumor cell lines are thoroughly described in the 1970s by Fogh and coworkers (Fogh \& Trempe 1975, Fogh et al.1977). The tumor cells are cultured as spheroids (Sutherland 1981, 1988) which are three dimensional avascular tumor nodules that are intermediates between in vitro monolayer cultures and in vivo tumors.

The other cell type involved in the angiogenic phenomenon, is the microvascular endothelial cell. Folkman along with the group of Davidson were the first to describe the isolation and cultures of microvascular endothelial cells (Folkman et al.1979, Davidson et al.1980). Information on the behavior of the endothelial cell in culture is essential for the establishment of an angiogenic model. Endothelial cells have a limited life span, are anchorage dependent and sensitive to contact inhibition. Endothelial cells can not be cultured indefinitely, although it is possible to culture some endothelial cells for over a year without significant changes (Booyse et al.1975). Capillary endothelial cells behave differently compared to venous and aortic endothelial cells (for a review see Kumar et al.1987) which is an important aspect in the context of tumor angiogenesis. Therefore large vessel endothelial cells are not the most logic cells to study the angiogenic phenomenon. However, the accessibility of microvascular endothelial cells is limited. It has been reported however, that venous endothelial cells of the umbilical vein do have similarities with the microvascular endothelial cells (Gospodarowicz et al.1979, Schwartz. 1978, Montesano 1992). Therefore, to establish the model to study the mitogenic effect of 
tumor spheroid conditioned medium on the endothelial cell, we started our experiments with human umbilical vein endothelial cells. To obtain umbilical vein endothelial cells we employed a modified method of Jaffe (Jaffe et al.1973) as will be described below. Once the model proved useful, we continued the study with capillary endothelial cells, which were kindly provided by Dr. M. Furie, University of Stony Brook, Dept. Pathology, Stony Brook NY, USA. The criteria to identify the homogeneity of the endothelial cell population is extensively reviewed (McAuslan et al.1988) and will not be discussed further hore.

\section{Materials and Methods.}

\section{Endothelial cells.}

Primary human umbilical vein endothelial cells (HUVE) were isolated according to the modified method of Jaffe (Jaffe et al.1973).

Umbilical cords were kindly provided by the Gynaecology Department of the Academic Hospital Maastricht, Maastricht, the Netherlands. A segment of the cord was isolated by ligature at both ends. Using two sterile canules (Delvo, Vetin BV, Netherlands) the interior was rinsed free of contaminating blood elements with phosphate buffered saline (PBS) containing: $\mathrm{NaCl}(0.15 \mathrm{M}), \mathrm{Na}_{2} \mathrm{HPO}_{4} .2 \mathrm{H}_{2} \mathrm{O}(8 \mathrm{mM})$ and $\mathrm{KH}_{2} \mathrm{PO}_{2}(1.6 \mathrm{mM}) \mathrm{pH} 7.4$ (Merck). Then Trypsine, containing $\mathrm{NaCl}(0.14 \mathrm{M}), \mathrm{KCl}(5.4 \mathrm{mM}), \mathrm{C}_{6} \mathrm{H}_{12} \mathrm{O}_{6} . \mathrm{H}_{2} \mathrm{O}(5 . \mathrm{l}$ $\mathrm{mM}$ ), $\mathrm{NaHCO}_{3}(6.9 \mathrm{mM})$, EDTA (Tritiplex III) (0.54 mM) (Merck), Trypsine (Difco, Detroit MI) (1:250) $0.5 \mathrm{gr} / \mathrm{l}$ and Phenol Red (Flow) 2\%, pH 7.3, was infused and the two ligature ends closed and the cord was incubated for 20 minutes at $37{ }^{\circ} \mathrm{C}$. The suspension was collected in a $50 \mathrm{ml}$ tube (Greiner) containing $5 \mathrm{ml}$ standard culture medium RPMI1640 (FLOW) + 20\% human serum (provided by the bloodbank of the Academic Hospital Maastricht, Netherlands) + antibiotics $(100 \mathrm{IU} / \mathrm{ml}$ Penicillin and $100 \mu \mathrm{g} / \mathrm{ml}$ Streptomycin) (HUVRPMI) and centifuged. The pellet was resuspended in HUVRPMI and placed in a fibronectin (a kind gift of Dr. C. Reutelingsperger, Biochemistry department, University of Limburg, the Netherlands) coated $25 \mathrm{~cm}^{2}$ culture flask (Costar, Cambridge) and incubated in a humidified chamber at $37{ }^{\circ} \mathrm{C}$ with $5 \% \mathrm{CO}_{2}$ for two hours after which the medium was refreshed.

To establish growth patterns, Endothelial Cell Growth Supplement (Collaborative Res. Inc.) and heparin (100 IU/ml) (LEO Pharmaceuticals, Weesp, Netherlands) were added to the cultures in different concentrations (table 1).

Bovine capillary endothelial cells $(B C E)$ were cultured in Minimal Essential Medium $\alpha$ modification (Flow) with 15\% Donor Calf Serum (Flow) (BCEMEM), on gelatin (Fluka Chemie, Switzerland) coated culture flasks (Costar). A stock supply was kept in liquid nitrogen.

As for the HUVE cells, different culture media were used to evaluate the proliferation of BCE cells in different culture conditions (table 1).

Supportive medium for HUVE cells was RPMI1640 + $5 \%$ human serum (SRPMI) and for BCE cells $\alpha$-MEM $+5 \%$ DCS (SMEM).

In experimental conditions when tumor conditioned medium was added, this conditioned medium was mixed with supportive medium $(1: 1 \mathrm{v} / \mathrm{v})$ before adding to the cultures. 
Viability of the endothelial cells, both before as well as after treatment, was determinedl by using Trypan-blue dye exclusion.

\section{Tumorcells.}

The tumor cell lines. HT29, SW620, SW480 and CaCo-2 were a gift from the Departmerit of Pathology, University of Limburg. Maastricht, the Netherlands. They were cultured in Dulbecco's Modified Eagles Medium (DMEM, Life Technologies, Breda, Netherlands) with $10 \%$ Bovine Calf Serum (BCS, Hyclone, Seralab) as monolayers in $25 \mathrm{~cm}^{2}$ culture flasks (Costar) to maintain the cell line.

\section{Tumor spheroids.}

Three dimensiona! spheroids were cultured according the modification described by Carlsson (Carlsson and Yuhas 1984). Briefly, 1000 tumor cells of either one of the cell lines used, were plated on sterile non-adhesive culture dishes and refreshed every second day. After two days the conditioned medium was collected and stored at $4{ }^{\circ} \mathrm{C}$ for several weeks. During culturing, the cells formed small spheroids and could be maintained in culture for several months.

\section{Tumor conditioned medium.}

The medium in which tumor cells (grown as monolayer or as threedimensional spheroids) were cultured was collected every two days. This tumor conditioned medium (TCM) was used to incubate the endothelial cells with.

Proliferation assay for endothelial cells.

HUVE and BCE cells were cultured until confluency in 6-wells plates, then conditioned medium of either tumor monolayers or tumor spheroids was added (1:1 v/v with SMEM or SRPMI) to the endothelial cell cultures for 24 hours, followed by administration of bromodeoxyuridine (final concentration $10 \mu \mathrm{M}$ ) for 30 minutes, after which the cells were washed with PBS and harvested. Cytospin preparations of the cells are made with a cytospin centrifuge (Cyto-tek, Ames-Miles Division, Bayer, Netherlands). The cytospins were fixed in $10 \%$ buffered formalin for 30 minutes, rinsed in destilled water and air dried.

\section{Immunocytochemistry for cytospin preparations.}

The cytospins were stained according to the procedure of Schutte (Schutte et al.1987).

Briefly, endogenous peroxidase was inhibited with $\mathrm{CH}_{3} \mathrm{OH} / \mathrm{H}_{2} \mathrm{O}_{2} 0.01 \%$ (Merck) for 10 minutes, washed in PBS, digested 30 minutes in $0.01 \mathrm{mg} / \mathrm{ml}$ pepsin (Boehringer Mannheim GmbH, Germany) in $0.1 \mathrm{~N} \mathrm{HCl}$, washed in PBS, incubated in $2 \mathrm{~N} \mathrm{HCL}$ for 30 minutes at $37{ }^{\circ} \mathrm{C}$ and then washed twice in Borax-buffer ( $0.1 \mathrm{M} \mathrm{Na}_{2} \mathrm{~B}_{4} \mathrm{O}_{7}$ (Merck) in destilled water) and once in PBS. The cytospins of the HUVE-cells then were preincubated with normal goat-serum (1:10 diluted in PBS/BSA $1 \mathrm{mg} / \mathrm{ml})$ for one hour. The BCE-cells were pre-incubated in PBS/Bovine Serum Albumin 1.5\% (Sigma), also for 60 minutes. The primary antibody (anti-BrdU 1:10.000 diluted in PBS/BSA $0.1 \%$ ) was added and incubated for one hour at $37{ }^{\circ} \mathrm{C}$ or overnight at $4{ }^{\circ} \mathrm{C}$. Again the cytospins were washed twice in PBS and incubated with peroxidase labeled Rabbit-anti-Mouse IgG 1:200 
(ITK Diagnostics, Uithoom, Netherlands) for 60 minutes at room temperature. The preparations were stained with a chromogen solution $(5 \mathrm{mg} / \mathrm{ml} 3.3$ Diaminobenzidin in $0.05 \mathrm{M}$ Trismabase (SIGMA) in aquadest $\mathrm{pH} \mathrm{7.6)}$ for 3 minutes, counter stained with Haematoxylin $\left(\mathrm{C}_{16} \mathrm{H}_{14} \mathrm{O}_{6} \mathrm{H}_{2} \mathrm{O}\right.$, Merck) dehydrated in a sequence of ethanol $70 \%, 96 \%$ and $100 \%$ and enclosed in Entellan (Merck).

\section{Labeling Index (LI).}

The cytospin preparations were, after immunocytochemistry, examined under a phase contrast microscope with an occular grid. The BrdU positive cells were counted as the percentage of the total number of cells (LI). At least 400 cells per cytospin were counted.

\section{Statistics.}

Statistical analysis was performed using the Wilcoxon Mann Whitney test.

\section{Results and discussion.}

In order to find the best conditions to test mitogenic properties of tumor cells, we first incubated HUVE cells for 24 hours with a variety of supplemented media and measured the proliferation rate with the bromodeoxyuridine incorporation assay. Separate batches of HUVE cells showed a wide variety in labeling indices and therefore a pool of 5-7 different isolations of venous endothelial cells from umbilical cords was tested. A decrease in labeling index of the proliferating HUVE cells was seen after three or more passages as shown in table 1.

Table 1. HUVE cells (pool of 5 isolations) cultured in various media. Labeling Index (LI) of 3 passages.

Madium

$\begin{array}{ll} & \text { LI }( \pm \text { s.d. }) \\ \text { passage I } & \text { passage } 2\end{array}$ passage 3

1. RPMI $+20 \%$ HS

2. $\mathrm{RPMI}+10 \% \mathrm{HS}$

3. $\mathrm{RPMI}+10 \% \mathrm{HS}+15 \mu \mathrm{g} / \mathrm{ml} \mathrm{ECGS}$

4. RPMI $+10 \% \mathrm{HS}+30 \mu \mathrm{g} / \mathrm{ml}$ ECGS

5. $\mathrm{RPMI}+5 \% \mathrm{HS}$

6. $\mathrm{RPMI}+5 \% \mathrm{HS}+15 \mu \mathrm{g} / \mathrm{ml} \mathrm{ECGS}$

7. RPMI $+5 \% \mathrm{HS}+30 \mu \mathrm{g} / \mathrm{ml} \mathrm{ECGS}$

8. RPMI $+90 \mu \mathrm{g} / \mathrm{ml} \mathrm{ECGS}$

9. $\mathrm{RPMI}+150 \mu \mathrm{g} / \mathrm{ml}$ ECGS

10. RPMI + I\% HS

$\begin{array}{ccc}11( \pm 3.9) & 12( \pm 5.7) & 8( \pm 2.1) \\ 9( \pm 4.7) & 8( \pm 3.1) & 4( \pm 0.5) \\ 12( \pm 2.8) & 13( \pm 2.4) & 7( \pm 2.4) \\ 15( \pm 3.5) & 13( \pm 2.5) & 9( \pm 1.4) \\ 5( \pm 0.8) & 4( \pm 0.8) & 4( \pm 2.7) \\ 9( \pm 3.7) & 9( \pm 2.2) & 7( \pm 2.6) \\ 12( \pm 2.6) & 11( \pm 2.8) & 8( \pm 3.5) \\ 10( \pm 1.1) & 9( \pm 2.4) & 1( \pm 0.9) \\ 9( \pm 2.2) & 12( \pm 4.1) & 2( \pm 0.5) \\ 2( \pm 1.9) & 0 & 0\end{array}$

RPMI= RPMI1640; HS= Human Serum; ECGS=Endothelial Cell Growth Supplement.

Therefore, all tests performed contained only HUVE cells in the first three passages. $\mathrm{BCE}$ were obtained from one batch and were much more constant in their proliferation characteristics, although there was a difference in the endogenous basic FGF level 
between populations and consequently a difference in basic proliferation levels (Tsuboi et al.1990). The BCE cells used here were between passage 15 and 20 .

The influence of different supplemented media on the labeling indices of HUVE as well as BCE cells was investigated (table 2).

From these data it was concluded that medium with $5 \%$ serum (SRPMI or SMEM) for both HUVE and BCE cells supported cell growth and allowed the detection of stimulatory or inhibitory effects due to tumor conditioned media.

Table 2. Media for endothelial cells.

\begin{tabular}{|c|c|c|c|c|}
\hline Cells & Medium & $\begin{array}{l}\text { Sernm } \\
\text { Concentration } \\
(\%)\end{array}$ & $\begin{array}{l}\text { Growth Factor } \\
\text { Concentration } \\
(\mu \mathrm{g} / \mathrm{ml})\end{array}$ & $\begin{array}{l}\text { Labeling } \\
\text { Index (\%) } \\
( \pm \text { s.d.) }\end{array}$ \\
\hline HUVE' & $\begin{array}{l}\text { 1. RPMII640 } \\
\text { 2. RPMII640 } \\
\text { 3. RPMII640 } \\
\text { 4. RPMII640 } \\
\text { 5. RPMI } 1640 \\
\text { 6. RPMI } 1640 \\
\text { 7. RPMII640 } \\
\text { 8. RPMI } 1640 \\
\text { 9. RPM }[1640 \\
\text { 10. RPMI } 1640\end{array}$ & $\begin{array}{c}20 \\
10 \\
10 \\
10 \\
5 \\
5 \\
5 \\
0 \\
0 \\
1\end{array}$ & $\begin{array}{c}0 \\
0 \\
15 \\
30 \\
0 \\
15 \\
30 \\
90 \\
150 \\
0\end{array}$ & $\begin{array}{c}10( \pm 4.54) \\
7( \pm 3.95) \\
11( \pm 3.68) \\
12( \pm 3.62) \\
4( \pm 0.75) \\
8( \pm 3.10) \\
10( \pm 3.38) \\
7( \pm 3.12) \\
8( \pm 4.58) \\
2( \pm 1.93)\end{array}$ \\
\hline BCE" & $\begin{array}{l}\text { 1. } \alpha \text {-MEM } \\
\text { 2. } \alpha \text {-MEM } \\
\text { 3. } \alpha \text {-MEM } \\
\text { 4. } \alpha \text {-MEM } \\
\text { 5. } \alpha \text {-MEM }\end{array}$ & $\begin{array}{c}20 \\
15 \\
10 \\
5 \\
1\end{array}$ & $\begin{array}{l}0 \\
0 \\
0 \\
0 \\
0\end{array}$ & $\begin{array}{r}10( \pm 0.68) \\
8( \pm 0.58) \\
7( \pm 1.52) \\
6( \pm 0.91) \\
6( \pm 1.15)\end{array}$ \\
\hline
\end{tabular}

\# Labeling Index is the mean of 3 passages in culture, obtained from a pool of 5 different endothelial cell populations.

* Labeling Index is the mean of one batch of BCE cells in 5 different passages.

The labeling index of HUVE cells after incubation with conditioned medium from either monolayers or spheroid-cultures increased significantly (figure 1) 


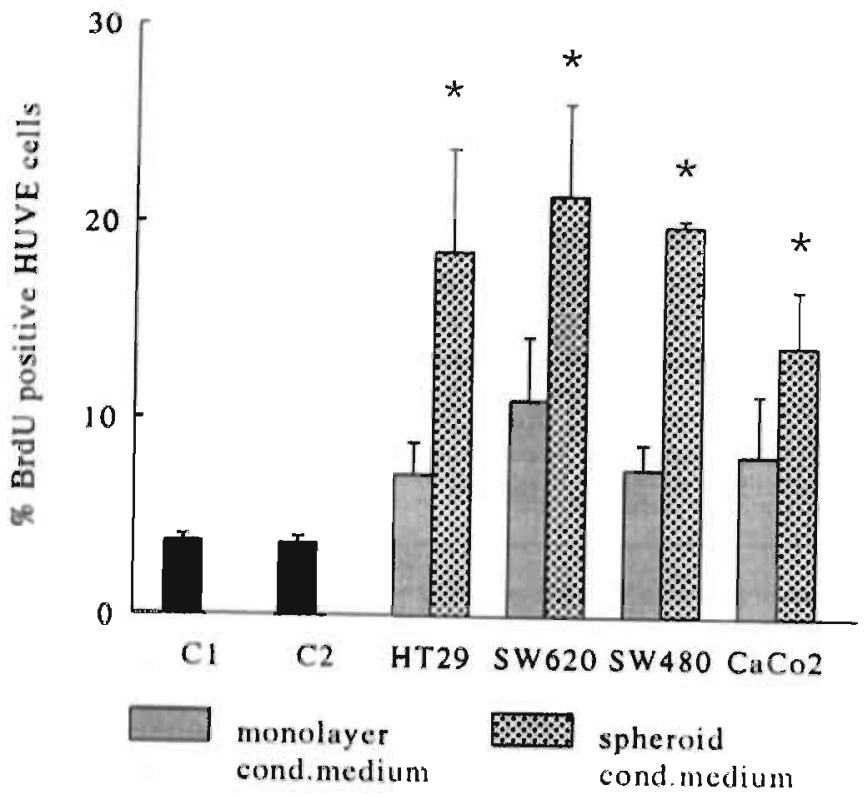

Figure 1.

Labeling index of HUVEC after 24 hour incubation with fumor conditioned medium. $(\oplus \mathrm{P}<0.05)(\mathrm{Cl}$ is SRPMI and C2 is SRPMI/DMEM $v / v 1: I)$.

This was consistent with the findings of Folkman, who used tumor conditioned medium to grow endothelial cells in (Folkman et al.1979). The labeling index was enhanced about 5fold compared to control values, when spheroid-conditioned medium was used. In general, the mitogenic effect of spheroid conditioned media exceeded that of the monolayer derived media 1.5- to 2-fold. With BCE cells, similar results were obtained, although at a slightly higher level of proliferative activity as is shown in figure 2.

Again, in all cases the spheroid conditioned media were more mitogenic than monolayer conditioned media, with SW620 reaching the highest labeling. Such a labeling index suggested that virtually all endothelial cells were actively cycling. Comparing the four cell lines, SW620 was the most mitogenic in both HUVE- and BCE-cell populations with a minimum of $11 \%$ and a maximum of $22 \%$ labeling. $\mathrm{CaCo} 2$ on the other hand in most experiments belonged to the least active cell lines, with a minimum at $8 \%$ and a maximum of $14 \%$ labeling. 


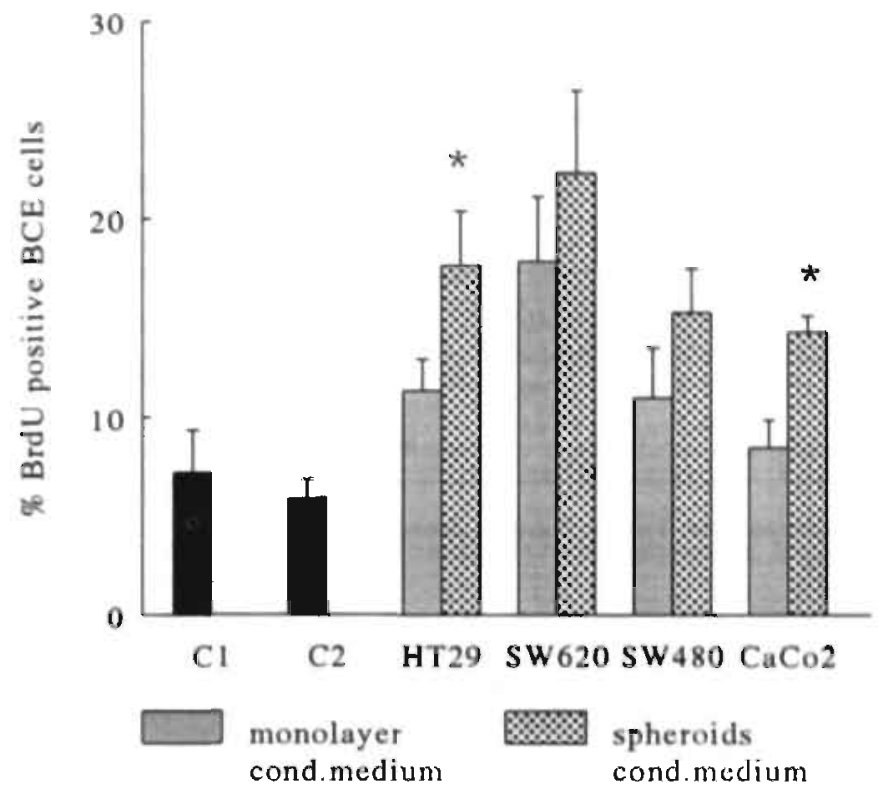

Figure 2.

Labeling index of BCE cells after 24 hour incubation with tumor conditioned medium. $\left({ }^{*} \mathrm{P}<0.05\right)(\mathrm{Cl}$ is SMEM and C2 SMEM/DMEM $v / v 1: 1)$.

These mitogenic differences were not correlated to ploidy levels or cytokinetics of these lines if grown as xenografts in nude mice, as can be seen by comparing these data with those of table 3. It was of interest to note however, that of 13 cell lines tested the $\mathrm{CaCo}-2$ xenograft was found to be unique in that it did not show in vivo growth despite a growth fraction of $50 \%$ and potential doubling time of 40 hours. This points to the possibility that also in vivo this cell line could be relatively deficient in angiogenic properties.

Human colorectal cancer cell lines differed in their capacity to release mitogenic activity for endothelial cells. One hypothesis to explain these differences might be that this possibly angiogenic activity is related to the growth characteristics of the tumor, e.g. its proliferative potential or propensity to necrosis. We did not find a relation with cytokinetics of the colorectal cancer cell lines if grown as xenografts in nude mice (table 3). A more direct comparison between the proliferation within the spheroids and their mitogenic potential for endothelial cells will be described in chapter 3 . 
Table 3. Characteristic of human colorectal cancer cell hines grown as xenografts in nude mice."

\begin{tabular}{|c|c|c|c|c|c|c|}
\hline & & Cytokinetics & & & & \\
\hline Cell line & $\begin{array}{l}\text { Ploidy } \\
\text { DNA index }\end{array}$ & $\mathbf{L I}(\%)$ & TS (hours) & Tpot (hours) & $\begin{array}{l}\text { Growth } \\
\text { Fraction }\end{array}$ & Differentiation \\
\hline $\mathrm{CaCo} 2$ & 1.90 & 16.9 & 6.5 & 40.2 & 0.50 & moderately \\
\hline $5 W 480$ & 1.20 & 23.6 & 8.2 & 34.7 & 0.68 & poorly \\
\hline HT29 & 1.53 & 16.4 & 7.2 & 46.3 & 0.58 & poorly \\
\hline sw620 & 1.27 & 17.7 & 6.3 & 35.9 & 0.32 & poorly \\
\hline
\end{tabular}

$L I=$ Lubeling Index; TS $=$ S-phase duration time; Tpot $=$ Potential doubling time.

b) Blijham et al. 1987.

In summary, the tumor spheroid model may be usefull to determine tumor-endothelial cell interactions and their regulation in a direct way. Sofar we have described a mitogenic effect of spheroids on endothelial cells and found this activity not to be dependent on the occurence of necrosis or inherent proliferative activity of the tumor cell line. Experiments to characterize this mitogenic activity and to expand our observations to invasive endothelial cell properties are in progress.

\section{References.}

Blijham GH, Schutte B, Verstijnen C. Arends JW, Reynders M, Bosman F. In vivo and in vitro cytokinetic studies on 13 human colorectal (HCC) cell lines. Am. Soc. Clin. Oncol. 6, 18, 1987.

Booyse FM, Sedlak BJ, Raffelson ME. Culture of arterial endothelial cells. Characterisation and growth of bovine aortic cells. Thromb. Diath. Haemorrh. 34, 825, 1975.

Coffey RJ, Goustin AS, Soderquist AM, Wolfshohl J, Carpenter G, Moses HL: Transforming growth factor alpha and beta expression in human colon cancer lines: implications for an autocrine model. Cancer Res. 47(17), 4590, 1987.

Carlsson J, Yuhas JM: Liquid-overlay culture of cellular spheroids. In Recent Results in Cancer Research 95, 1-23, 1984.

Culouscou JM, RemacleBonnet M, Garrouste F, Marvaldi J, Pommier G: Simultaneous production of IGF-I and BGF growth factors by HT-29 human colon cancer line. Int. J. Cancer 40(5), 646, 1987.

Davidson P, Bensch K, Karasek M. Isolation and growth of endothelial cells from the microvessels of the newhom human foreskin in cell culture. J. Invest. Derm. 75, 316-321, 1980.

Fenselau A, Mello RJ: Growth stimulation of cultured endothelial cells by tumour cell homogenates. Cancer Res. 36: 3269, 1976.

Fogh J, Trempe P. New human tumor cell lines. In Human tumor cells in vitro, New York Plenum Press. Editor J. Fogh, 1975. 


\section{2}

Fogh J, Fogh JM, Orleo T. One hundred and twenty seven cultured human tumor cell lines producing tumors in nude mice. J. Natl. Cancer Inst. 59, 221-226, 1977.

Folkman J. Haudenschild C, Zetter B. Long-term culture of capillary endothelial cells. Proc. Natl. Acad. Sci. U.S.A. 76, 5217, 1979.

Gospodarowicz D, Balecki H, Greenburg G, Zetter BR. Factors involved in the moalulation of cell proliferation in vivo and in vitro: the role of fibroblast and epidermal growth factors in the proliferative response of mammalian cells. In vitro $14,85,1979$.

Jaffe EA, Nachman RL, Becker CG, Minick CR. Culture of human endothelial cells derived from umbilical veins. J. Clin. Invest. 52, 2745, 1973.

Kumar S, West D, Ager A. Heterogeneity in endothelial cells from large and microvessels. Differentiation 36, 57-70, 1987.

Maciag T. Molecular and cellular mechanisms of angiogenesis. Important Adv. Oncol. 85-98, 1990.

McAuslan BR, Hannan GN, Reilly W. Bovine endothelial cell cultures as a model system for studies on tumor angiogenesis. In: In vitro models for Cancer Research Volume IV, M. Webber editor, CRC Press, Boca Raton, Floridı, Chapter 7, 117-154, 1988.

Paweletz N, Knierim M. Tumor related angiogenesis. Crit. Rev. Oncol. Hematol., 9 (3), 197-242, 1989.

Presta M, Rifkin DB. New aspects of bloodvessel growth: tumor and tissue derived angiogenesis factors. Haemostasis 18, 6-17, 1988.

Schutte B, Reynders MMJ, Bosman FT, Blijham GH. The effect of tissue fixation on antibromodeoxyuridine immunohistochemistry. J. Histochem. Cytochem. 35, 1343-1345, 1987.

Schwartz SM. Selection and characterisation of bovine aortic endothelial cells. In vitro 14, 966, 1978.

Shing Y, Folkman J, Sullivan R, Butterfield C. Heparin affinity: purification of a tumor-derived capillary endothelial cell growth factor. Science 223, 1296-1298, 1984.

Sutherland RM. Cell and environmental interactions in tumor microregions. The multicell spheroid model. Science 240, 177-184, 1981.

Sutherland RM. Spheroids in cancer research. Cancer Res. 41, 2980-2984, 1988.

Tsuboi R, Sato Y, Rifkin DB: Correlation of cell migration, cell invasion, receptor number, proteinas: production and basic fibroblast growth factor levels in endothelial cells. J. Cell Biol. 110, 511-5.17, 1990.

Warren BA, Greenblatt M, Kommineni VRC: Tumour angiogenesis: ultrastructure of endothelial cells in mitosis. Br. J. Exp. Pathol. 53: 216, 1972. 



\title{
Chapter 3.
}

\section{Mitogenic properties of tumor spheroids for endothelial cells are related to their age.}

\author{
Lichtenbeld H.C., Blijham G.H. Mitogenic properties of tumor spheroids for endorhelial \\ cells are related to their age. Endothelium 1993 (in press).
}

\begin{abstract}
Abstmact.
The mitogenic effest of spheroids of the human colorectal cances cell line HT29 on monolayer of bovine capillary endothelial cells was investigated in order to determine the relationship between aspects of threedimensional tumor growh and endothelial cell mitogenesis. Spheroid conditioned media caused a significant increase in LI of endothelial cells over control values. An inverse relationship was found between the age of spheroids and their ability to produce endothelial mitogens. Young (day 5) spheroids induced a significant higher LI in endothelinl cells: than more mature ones. The decrease in mitogenicity preceeded the development of necrosis in the spheroids. Furthermore, conditioned medium from mature (day 21) spheroidn suppresses the mitogenic activity from young spheroids to a significant degree, indicating that larger tumor nodules may produce inhibitors of endothelial cell proliferation. The model described here indicates that further studies with young and mature spheroids could provide important information on the regulating mechanisms exerted by growing tumor nodules on tumor associated angiogenesis.
\end{abstract}

\section{Introduction.}

Angiogenesis is a key feature of malignant growth (Folkman 1990). Several factors have been described that enable tumor cells to induce the angiogenic process which involves endothelial cell activation, digestion of the extracellular matrix by collagenases and proteases, endothelial cell migration, proliferation and finally the formation of new capillaries (Paweletz \& Knierim 1989). Little is known, however, about the regulation of this angiogenic capacity in relation to the growth rate and size of threedimensionally growing tumors.

Do small tumor nodules secrete endothelial cell growth factors irrespective to size and necrosis or does this activity only occurs once a critical size or growth rate of the tumor has been established? Answers to these questions are important in order to understand why human tumors appear to differ in their angiogenic potential as has been shown for breast (Weidner et al.1991), cervical (Sillman et al.1981) and bladder (Chodak et al.1980) cancer as well as to develop clinically relevant anti-angiogenic strategies.

We employed the tumor-spheroid model (Sutherland 1981, 1988) and investigated the relationship between spheroid age, size, necrosis and proliferation rate and one aspect of the angiogenic process, the induction of endothelial cell proliferation. 
Materials and methods.

Endothelial cells and tumor cells.

Bovine capillary endothelial (BCE) cells were kindly provided by Dr.M.Furie, Stony Brook NY through the courtesy of Dr. M. Montesano, Geneva, Switzerland.

$\mathrm{BCE}$ cells were cultured in minimal essential medium, alpha modification ( $\alpha$-MEM) (GIBCO) supplemented with $15 \%$ Donor Calf Serum (DCS, Flow Laboratories). In experiments the endothelial cells were cultured in supportive medium, alpha-MEM with $5 \%$ serum (SMEM). BCE cells were seeded in 6-wells culture plates and at confluency $\left(3.8 \times 10^{5}\right.$ cells) the cells were washed once in SMEM immediately followed by performing the experiments.

For tumor cells the human colorectal cancer cell line HT29 (Fogh et al.1975, 1977) was used.

The cells were cultured in Dulbecco's Modified Essential Medium (DMEM) (GIBCO) with 10\% Bovine Calf Serum (Hyclone).

\section{Spheroids and spheroid conditioned media.}

Tumor spheroids of age between 1 and 35 days were grown in $10 \mathrm{~cm}$ diameter culture dishes (Costar) coated with $0.5 \%$ agarose in destilled water to prevent adherence (Carlsson and Yuhas 1984), starting with 1000 cells at day one.

To condition the medium tumor spheroids were grown in fresh medium (DMEM $+10 \%$ BCS) for 48 hours and approximately $4 \times 10^{5}$ tumor cells conditioned $1 \mathrm{ml}$ of culture medium. Subsequently the conditioned medium was collected and $1 \mathrm{ml}$ added to the confluent BCE monolayer cultures after mixing this $(1: 1 \mathrm{v} / \mathrm{v})$ with SMEM. Control is non-conditioned medium (DMEM) mixed ( $1: 1 \mathrm{v} / \mathrm{v})$ with SMEM.

At each time interval spheroids were randomly obtained from every dish and enzymatically degraded to count the average number of cells per spheroid per age.

Proliferation assay for BCE cells.

$\mathrm{BCE}$ cells were cultured with spheroid conditioned medium for 24 hours. Subsequently the thymidine analogue Bromodeoxyuridine (BrdU) was added to the cultures at a final concentration of $10 \mu \mathrm{M}$ for 30 minutes. Cytospin preparations of endothelial cells (Cytotek Centrifuge, Technicon Ames-Miles, Bayer Netherlands BV) were made, fixed 30 minutes in $4 \%$ neutral buffered formalin, washed in aquadest and air dried. The incorporated BrdU was visualized according to the method of Schutte (Schutte et al.1987). The percentage BrdU-positive cells relative to the total number of cells was determined (minimally 400 cells per cytospin counted) and expressed as the Labelling Index (LI).

\section{Proliferation of spheroids.}

To determine the proliferation rate in tumor spheroids, cultures were also incubated with BrdU (final concentration $10 \mu \mathrm{M}$ ) for 60 minutes. Subsequently tumor spheroids were fixed in $4 \%$ neutral buffered Formalin at $4^{\circ} \mathrm{C}$ ovemight, enclosed in agar $2.5 \%$, embedded in paraffin and sections were made and processed according to the previously mentioned method of Schutte. Three sections per time-point, containing 3-6 spheroids, were counted to determine the labelling index and the presence of necrosis. 
Statistics.

Results were statistically analysed by using the Wilcoxon Mann Whitney test.

Results.

In a series of experiments the effect of spheroid conditioned media on the proliferation of endothelial cells was examined. Results are shown in table 1.

Table 1. Labeling Index of BCE cells after 24 hour incubation with spheroid conditioned medium.

Spheroid age (days)

Control (SMEM)

Control (SMEM + DMEM)

5

7

14

21

28

35
BCE Labeling Indes ( \pm s.d.)

* $\mathrm{P}<0.05$ compared to control

\# $\mathrm{P}<0.05$ compared to other conditioned media

Two controls were used, one being the proliferation of endothelial cells cultured in SMEM and the other one being the proliferation of endothelial cells cultured in a mixture $(1: 1 \mathrm{v} / \mathrm{v})$ of SMEM with non-conditioned spheroid medium.

Spheroid conditioned media significantly increased the LI in endothelial cells, regardless the age of the spheroids that conditioned the medium. In particular spheroids of 5 days of age induced a very strong increase in the proliferation of endothelial cells, significantly more than did the conditioned medium of older spheroids. Obviously 5-days old spheroids are much smaller than mature ones, making it even more remarkable that these young spheroids have such profound mitogenic effect. To appreciate this phenomenon we determined the cell numbers of spheroids at various ages.

Results are shown in figure 1 and display that at least a 100 -fold difference exists between the cell numbers of HT29 spheroids less than 10 days of age and the mature ones. 


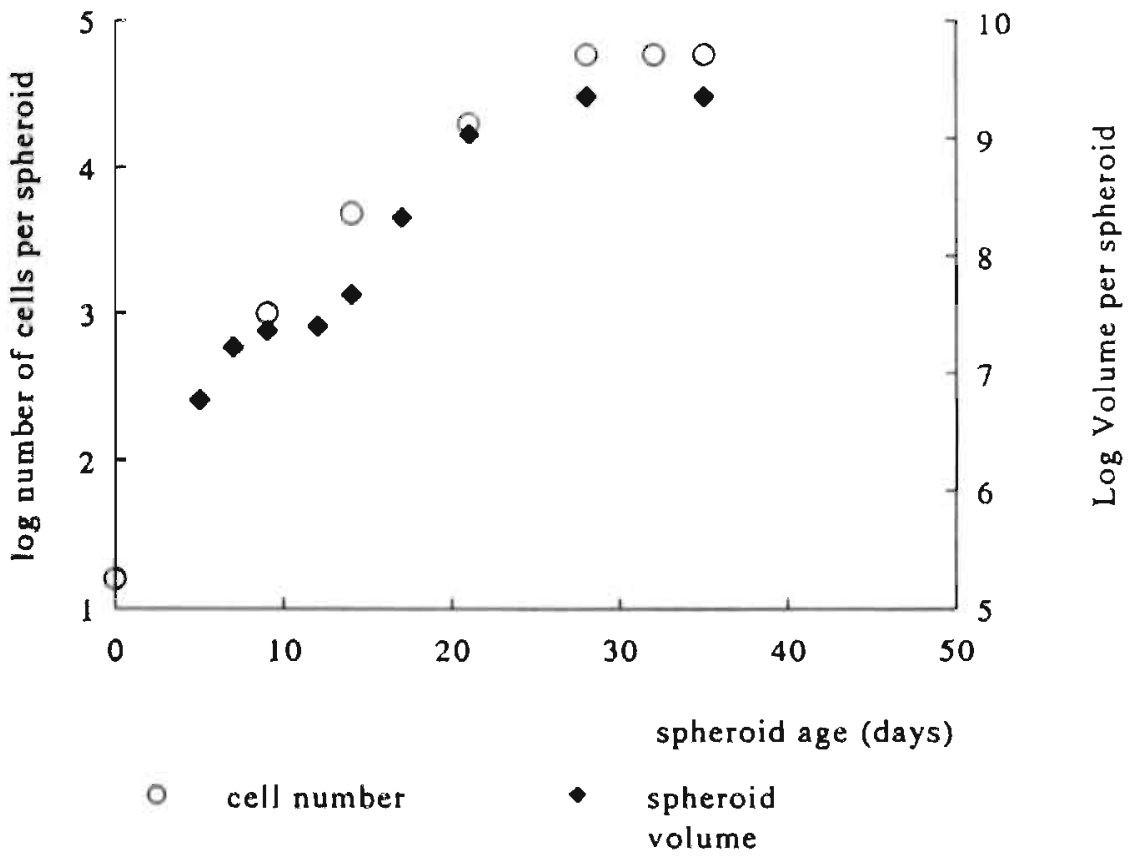

Figure 1. Growth curve (expressed as Log Volume) of the colo-rectal tumor cell line HT29 grown in a liquid overiay and tho log cell number per spheroid (calculated after enzymatically degradation) of randomly selected spheroids (in triplo) at different time points.

Is the ability of spheroids to produce mitogenic activity for BCE cells related to their growth rate or the occurrence of necrosis? In figure 2 the LI of spheroids is given in relation to their age. Young spheroids were actively proliferating with high labelling indices (between 30 and 50\%) and did not contain necrosis. Between day 14 and 21 some picnotic regions were observed and thereafter necrosis became more and more abundant. At the same time the LI decreased to $10 \%$ or less. The age related decrease in BCE mitogenic activity appears to be a relatively early event that occurs just before the onset of necrosis and despite continuing spheroid proliferation and growth. 


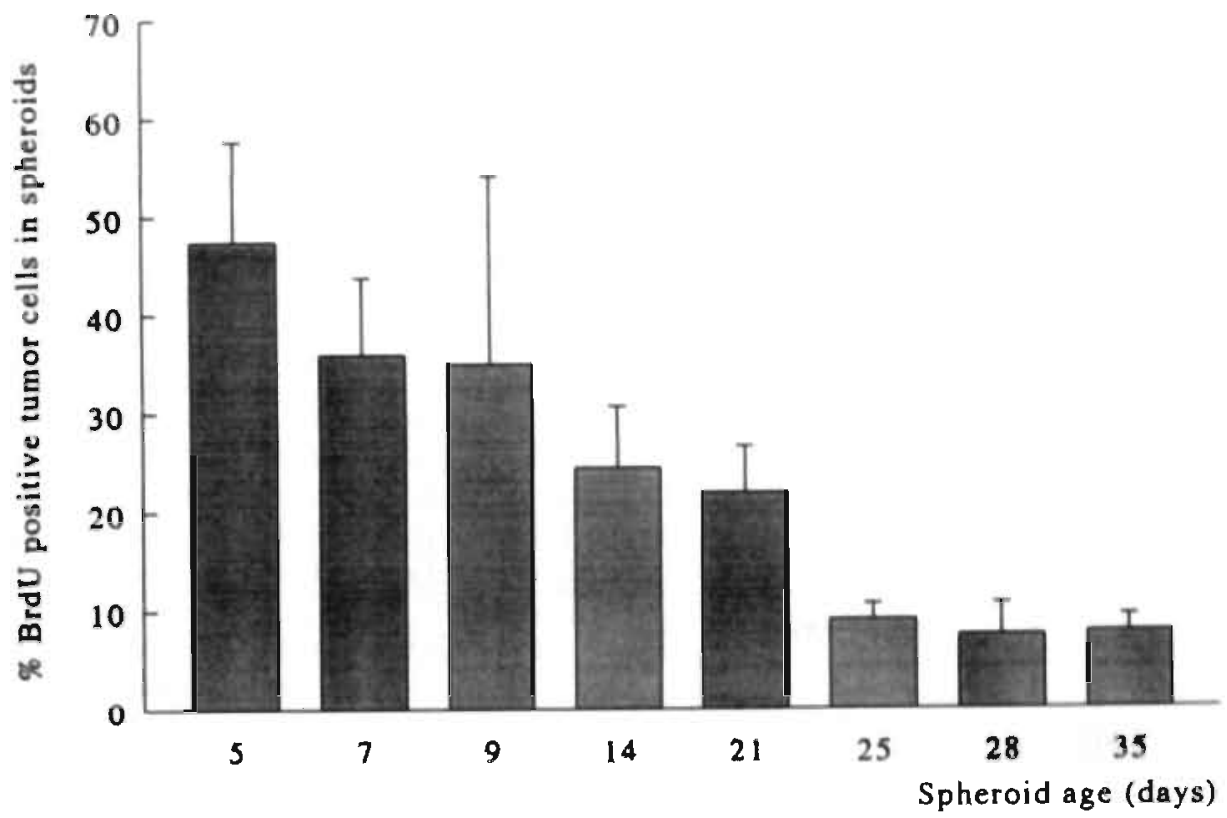

Figure 2. Decreasing Labeling Index of tumor spheroids (HT29) in time. At day one, 24 simultaneously cultured petridishes started with a cell suspension of 1000 cells.

The $\mathrm{LI}$ is determined at the various time intervals. Spheroid cultures (in triplo) were collected and embedded in paraffin and three cross sections from each culture was made. Every section contained at least 5 spheroids, of which the percentage BrdU positive cells was scored after immunostaining for BrdU.

Finally the hypothesis was examined that this decrease in mitogenic properties of mature spheroids is due to the production of inhibitors. Therefore conditioned media from 5 days old spheroids were mixed with conditioned media from 21 days old spheroids and this combination again mixed with SMEM $(1: 1 \mathrm{v} / \mathrm{v}$ with SMEM) and added to the endothelial cell cultures.

Figure 3 shows the LI of BCE cells under these (and control) conditions.

It appears that the medium of day 21-spheroids indeed suppresses the mitogenic activity derived from the young spheroids to a significant degree. 


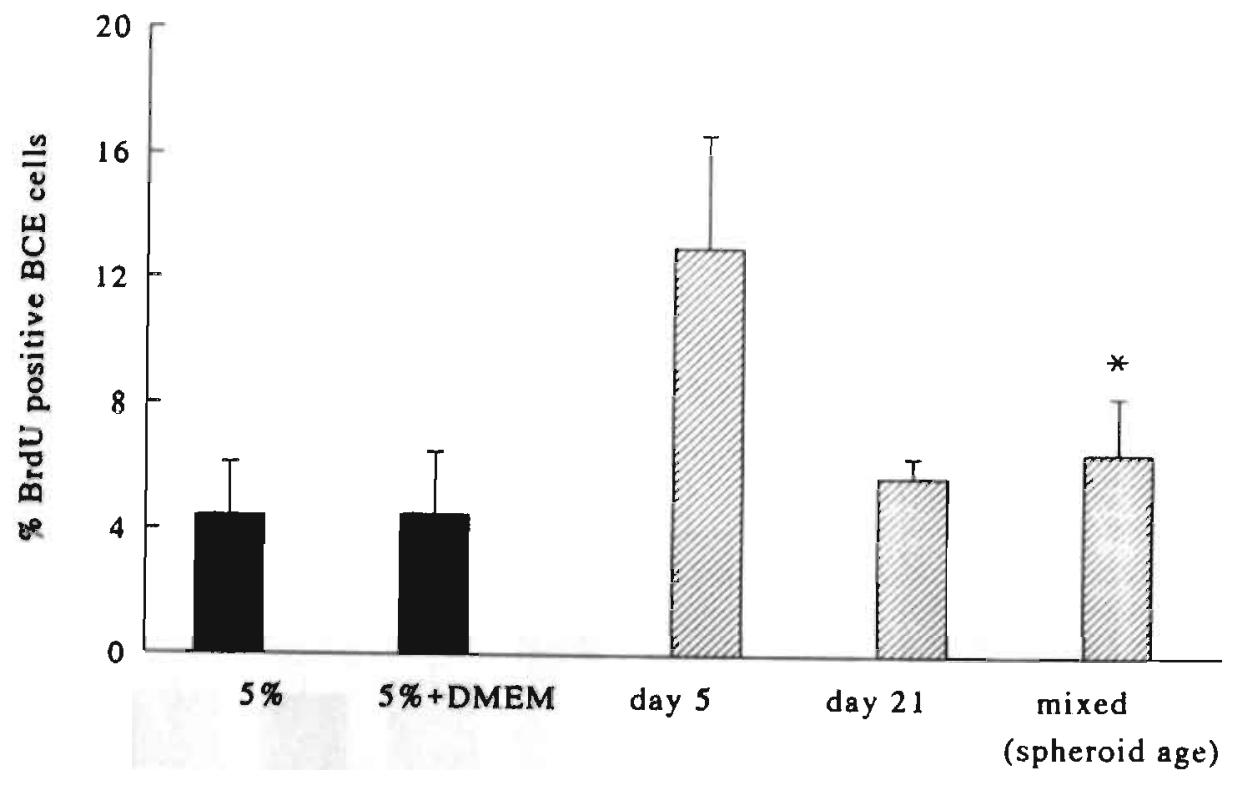

$\mathrm{BCE}+$

HT29 C.M.

Figure 3. LI of endothelial cells after incubation with conditioned medium from young spheroids (5 days), mature spheroids (21 days) and a mixture of conditioned medium from young and mature spheroids. Young spheroids did not contain necrosis and the percentage dead cells is $0 \%$, since we only considered the amount of dead cells within the tumor spheroid to be of major influence on the mitogenic properties of the conditioned medium. In contrast, the percentage dead cells is over $50 \%$ in mature spheroids.

( ${ }^{*} \mathrm{P}<0.05$ compared to day 3 ).

\section{Discussion.}

Tumor-associated angiogenesis is a complex process involving angiogenic and antiangiogenenic mediators, tumor cells and tumor-infiltrating cells, components of the extracellular matrix and endothelial cells.

Until the 1960s several aspects of this process have been elucidated by careful morphological studies (Erhlich 1879, Virchow 1863, Goldman 1907), thereafter the development of techniques like the hamster-cheek pouch (Greenblatt 1968) and the chick embryo chorioallantoic membrane model (CAM) (Ausprunk 1974) provided evidence that tumors produce diffusible factors that induce angiogenesis (Culouscou et al.1987). Cloned capillary endothelial cells became next available for studying the angiogenic phenomenon (Folkman 1979) and only recently artificial matrices were applied (Montesano 1985). These investigations have led to the isolation and purification of angiogenic factors (Folkman 1974, Liotta 1985, Folkman \& Klagsbrun 1987, Maciag 1990, Acker et al. 1990, Bicknell \& Harris 1991, Paku \& Paweletz 1991). Less attention has been paid to the regulatory aspects of angiogenesis as a process that starts and proceeds in dependency 
of certain aspects of actual tumor growth. We developed a model system using spheroids as three dimensional avascular growing tumor nodules. During their growth in culture they proceed from a small size, which in vivo is comparable to avascular growth, to a steady state with necrosis and arrested growth and therefor appear particularly suited to investigate the relationship between early tumor growth characteristics and angiogenesis.

Probably the most striking result of these experiments is the establishment of an inverse relationship between spheroid age and their ability to condition their medium for activity leading to endothelial cell mitogenesis. Young, small and non-necrotic spheroids seem to be most active (despite a 100-fold less amount of cells than mature spheroids) leading to a twofold higher LI.

Several possibilities may explain the consistently observed differences between young and mature spheroids in enhancing the LI of cultured endothelial cells. From our data it appears that endothelial cell mitogenesis and the proliferation of spheroids of various age tend to run in parallel. It may therefore be that in our system the mitogenic stimuli for proliferation of endothelial and tumor cells are identicall. Tumor cells produce several growth factors (Anzano et al.1989) among which members of the fibroblast growth factor (Klagsbrun 1989,1991, Maciag 1984). These growth factors have been described to stimulate endothelial cell proliferation as well as to be involved in the aulocrine stimulation of tumor growth. Alternatively, mature and necrotic spheroids may produce proliferation-inhibitors that not only slow down spheroid proliferation itself but also inhibit the proliferation of endothelial cells. Such inhibitory factors may be related to the oxygen-dependend proteins (Sutherland 1988) or to the secretion of agents that inhibit endothelial proliferation either in vivo or in vitro like TGF-B (Antonelli-Orlidge el al. 1989) and TNF- $\alpha$ (Leibovich et al. 1987). Acker and co-workers (Acker et al.1990) described an increased rather than a decreased cell mitogenesis from HT29 monolayers and spheroids cultured under hypoxic conditions, suggesting that hypoxia per se can not explain our findings. The results of our mixing experiments clearly favor the explanation that the presence of inhibitors rather than a deficiency in stimulatory activity plays an important role in the declined endothelial cell mitogenesis from mature spheroids.

We conclude that the model described is very well suited to further investigate the relations between aspects of actual growth such as the rate proliferation and the degree of differentiation and necrosis on one hand and the release of substances affecting endothelial cell activity on the other hand. Results obtained sofar indicate that the most mitogenic activity for endothelial cells is exerted by actively proliferating young tumor nodules; this is consistent with findings in human tumors that angiogenesis is limited to an area surrounding the rim of actively proliferating tumor cells, rather than to proceed to the necrotic parts of the tumor (Dvorak 1988). Further studies with this model may provide important information on the regulating mechanism in tumor angiogenesis.

\section{References.}

Acker H, Pietruschka F, Deutscher J. Endothelial cell mitogen released from HT29 tumour cells grown in monolayer or multicellular spheroid culture. Br. J. Cancer 62, 376-377, 1990. 
Antonelli Orlidge A, Saunders KB, Smith SR, D'Amore PA. Activated form of transforming growth factorbeta is produced by cocultures of endothelial cells and pericytes. Proc. Nat. Acad. Sci. U.S.A. 86, 45444548,1989

Anzano MA, Rieman D, Prichett W, Bowen-Pope DF, Greig R. Growth factor production by human colon carcinoma cell lines. Cancer Res. 49, 2898-2904, 1989.

Ausprunk DH, Knighton DR, Folkman J. Differentiation of vascular endothelium in the chick chorioallantois: a structural and autoradiographic study. Dev. Biol. 38, 237, 1974.

Bicknell R, Harris AL. Novel growth regulatory factors and tumour angiogenesis. Eur. J. Cancer 27(6), $781-85,1991$.

Carlsson J, Yuhas JM. Liquid-overlay culture of cellular spheroids. In Recent Results in Cancer Research 95, 1-23, 1984.

Chodak GW, Haudenschild C, Gittes RF, Folkman J. Angiogenic activity as a marker of neoplasia and preneoplasia in lesions of the human bladder. Ann. Surg. 192, 762-771, 1980

Culouscou JM, RemecleBonnet M, Garrouste F, Marvaldi J, Pommier G. Simultaneous production of IGF-I and EGF growth factors by HT-29 human colon cancer line. Int. J. Cancer 40(5), 646, 1987.

Dvorak HF. Tumors stroma. In Diagnostic Immunopathology. R.B. Colvin, A.K. Bahn, and R.T. McCluskey Eds. Raven Press, New York, 401-420, 1988.

Ehrlich P. Beitrage zur Kenntniss der Granulierten Bindegewebzellen und der Eosinophilen Leucocyten. Arch. Anat. Physiol. 3, 166-169, 1879.

Fogh J, Trempo P. New human tumor cell lines. In Human tumor cells in vitro, New York Plenum Press. Editor J. Fogh, 1975.

Fogh J, Fogh JM, Orleo T. One hundred and twenty seven cultured human tumor cell lines producing tumors in nude mice. J. Natl. Cancer Inst. 59, 221-226, 1977.

Folkman J. Proceedings: tumor angiogenesis factor. Cancer Res. 34, 2109, 1974.

Folkman J, Haudenschild C, Zetter B. Long-term culture of capillary endothelial cells. Proc. Natl. Acad. Sci. U.S.A. 76, 5217, 1979.

Folkman J, Klagsbrun M. Angiogenic factors. Science 235, 442, 1987.

Folkman J. What is the evidence that tumors are angingenesis dependent? J. Natl. Cancer Institute 82(1), 4-6, 1990.

Goldmann E. Growth of the malignant disease in man and the lower animals with special reference to vascular system. Proc. R. Soc. Med. 1, 1, 1907.

Groenblatt M, Shubik P. Tumor angiogenesis: transfitter diffusion studies in the hamster by the transparant chamber technique. J. Natl. Cancer Inst. 41,111-124, 1968.

Klagsbrun M. The fibroblast growth factor family: structural and biological properties. Prog. in Growth Factor Res. Vol. 1, 207-235, 1989. 
Klagsbrun M, D'Amore P. Regulators of angiogenesis. Ann. Rev. Physiol. 53, 217-239, 1991.

Leibovich SJ, Polverini PJ, Shephired HM, Wiseman DM, Shively V. Nuseir N. Macrophage induced angiogenesis is mediated by tumor necrosis factor alphal. Nature 329, 630-632, 1987.

Liotta LA. Isolation of a protein that stimulates blood vessel, growth. Nature 318, 14, 1985.

Maciag T. Angiogenesis. Prog. Hemostas. Throm. T: Herzl Spaet New York, 167, 1984.

Maciag T. Moleculur and cellular mechunisms of angiogenesis. Important Adv. Oncol. 85-98, 1990.

Montesano R, Orci L. Tumor-promoting; phorbol ester induce angiogenesis in vitro, Cell 42, 469-477, 1985.

Paku S, Paweletz N. First steps of tumor-related angiogenesis. Lab. Invest. 65(3), 334-346, 1991.

Paweletz N. Knierim M. Tumor related angiogenesis. Cril.Rev.Oncol.Hematol. 9(3), 197-242, 1989.

Schutte B, Reynders MMJ, Bosman FT, Blijham CiH. The effect of tissue fixation on antibromodeoxyuridine immunohistochemistry. J. Histochem. Cytochemt. 35, 1343-1345, 1987.

Sillman F, Boyce J, Furchter R. The significance of atypical vessels and neovascularisation in ceirvical neoplasia. Am. J. Obstet. Gynecol. 139, 154-159, 1981.

Sutherland RM. Spheroids in cancer research. Cancer Res. 41, 2980-2984, 1981.

Sutherland RM. Cell and environmental interactions in tumor microregions: The multivell spheroid model. Science $240,177-184,1988$.

Virchow R. "Die Krankenhaften Geschwülste". August Hirschwald, Berlin 1863, cited by Paweletz N. and Knierim M. in Tumor related angiogenesis. Critical Reviews in Oncology and Haematology Vol.9 (3) $197-$ $242,1989$.

Weidner N, Semple JP, Welch WR, Folkman J. Tumour angiogenesis and metastasis-coirrelation in invasive breast carcinoma. New Engl. J. Med. 324, 1-8, 1991. 


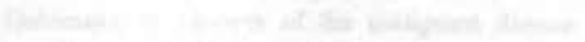

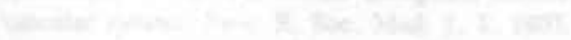

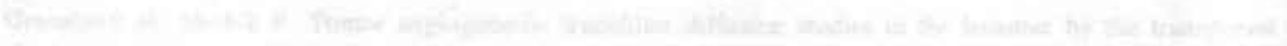

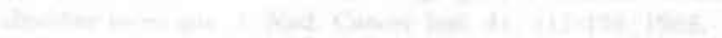

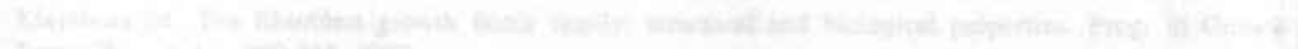

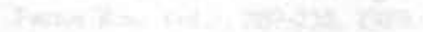




\title{
Chapter 4.
}

\section{Tumor spheroid induced vesicle formation on endothelial cells is associated with procoagulant properties.}

\author{
Lichtenbeld H.H.C., Muller A.D., Van Dam-Mieras M.C.E., Blijham G.H. Tumor \\ spheroid induced vesicle formation on endothelial cells is associated with procoagulant \\ properties. J. Cell Science (accepted).
}

\begin{abstract}
.
Fibrin deposits in tumor beds are an intruiging phenomenon. It has been suggested that fibrin plays a role. as a provisiona] matrix in which the tumor grows and induces development of a vascular network. On the other hand fibrin possibly protects the tumor nodule from hosil defense mechanisms. We therefore investigated whether tumor cells could induce a procoagulant response in endothelial cells leading to fibrin formation. For our studies we employed a modification of the matrix model of Montesanc in which sprouting of endothelial cell aggregates can be followed. This system allowed us to study in vitro the involvement of coagulation in tumor growth and angiogenesis.

Cocultures of endothelial cell aggregates and avascular tumor spheroids in collagen type I gels resulted in the appearance of extracellular vesicle-like structures on the endothelial sprouts. The vesicles formed on endothelial cell sprouts upon coculturing with tumor eells exhibited an increased amidolytic activity, suggestive for factor $\mathrm{X} / \mathrm{Xa}$ activity, not dependent on tissue factor exposure. Experiments using $\mathrm{HgCl}_{2}$ and lodoacetamide pointed to the importance of $\mathrm{SH}-\mathrm{groups}$ in the factor X/Xa activity on endothelial cell sprouts.
\end{abstract}

Introduction.

Fibrin deposits in tumor beds are intruiging phenomena (for a review, see Machovich 1987). These deposits have been suggested to promote tumor growth by providing a provisional matrix in which tumor cells can grow (Dvorak et al. 1987) and induce the development of a vascular network, which is crucial for succesful tumor growth (Folkman 1990). Furthermore, the fibrin matrix may protect the newly formed tumor nodule from the host-defense system (Donati et al.1981).

Several mechanisms may contribute to this peritumoral fibrin formation. For instance " mechanical damage of the endothelial cell can trigger fibrin formation via the extrinsic pathway of the coagulation cascade while inflammatory or immunogenic stimulation can initiate coagulation via the intrinsic pathway. It has also been found that certain tumors display a procoagulant activity, called Cancer Procoagulant (CP). This CP is a cysteine protease, distinct from the normal coagulation factors which are serine proteases (Gordon et al. 1975, Falanga and Gordon 1985). CP directly activates factor X to factor Xa and is not dependent on the factor VII/Tissue Factor complex (Gordon \& Mourad 1991). Recently, it has also been shown that induction of cellular adhesion molecules may contribute to coagulation activation at the level of factor X (Altieri \& Edgington 1988). Most probably both macrophages and endothelial cells are involved in determining the 
local procoagulant/anticoagulant balance.

We have recently shown that small as well as mature avascular tumor nodules (spheroids) exerts regulatory effects on endothelial cell proliferation (Lichtenbeld \& Blijham 1992). In the present study, we describe in vitro experiments on changes in procoagulant activity of endothelial cells after exposure to avascular tumor spheroids of the colorectal tumor cell line HT29. The avascular tumor nodules influence the procoagulant properties of endothelial cells in a way comparable to that recently described for viral stimulation of endothelial cells (Van Dam-Mieras et al. 1992).

\section{Materials and Methods.}

\section{Endothelial cells.}

Bovine Capillary lindothelial cells (BCE), kindly provided by Dr.M.Furie, University of New York, Stony Brook, U.S.A. were routinely cultured on gelatin coated culture flasks $\left(25 \mathrm{~cm}^{2}\right)$ in Minimal Essential Medium $\alpha$-modification (GIBCO) with 15\% Donor Calf Serum (DCS) (Flow Laboratories). No other supplements were added.

\section{Tumor cells.}

Colorectal tumor cell line HT29 (Fogh et al.1977) cells were cultured in Dulbecco's Modified Essential Medium (Flow Laboratories) supplemented with $10 \%$ Bovine Calf Serum (BCS) (Hyclone, Greiner).

\section{In vitro coculture of endothelial and tumor cells in a collagen matrix.}

This system is a modification of the model of Montesano (Montesano 1992).

Endothelial cells (BCE) were cultured until confluency $\left(1.8 \times 10^{6}\right.$ cells), trypsinized and transferred to a $35 \mathrm{~mm}$ dish coated with $0.5 \%$ agarose to prevent adherence and promote the formation of endothelial aggregates. After 24 hours the aggregates were separated from single cells by gravitational force, followed by embedding in a collagen type I gel (Vitrogen, Collagen Corp, Palo Alto) in a 96 wells plate (11 \pm 5 aggregates per well) in the presence or absence of HT29 cells ( 300 cells per well). The tumor cells were embedded in vitrogen as single cells and formed during the incubation time very young spheroids. The cultures were incubated for 48 hours in a humidified chamber at $37^{\circ} \mathrm{C}$ and $5 \% \mathrm{CO}_{2}$. Control cultures were respectively BCE aggregates or HT29 tumor spheroids alone embedded in vitrogen and incubated for 48 hours.

\section{Morphological studies.}

The endothelial cell aggregate cultures with or without the tumor cells were examined under a phase contrast microscope and photographs were taken $(200 \mathrm{x})$. Then the cultures were fixed in $2.5 \%$ glutaraldehyde in $\alpha$-MEM buffer and processed according to standard procedures for transmission electron microscopy (TEM). Briefly, the cultures were postfixed in $1 \%$ osmium tetroxide $\left(\mathrm{OsO}_{4}\right)$ and embedded in Epon $81 / 2$. Ultrathin sections were cut, counterstained with uranyl acetate and lead citrate, and evaluated with a Philips CM10 transmission electron microscope $(80 \mathrm{keV})$. Micrographs were taken. 
Chromogenic determination of factor $\mathrm{X} / \mathrm{Xa}$.

After 48 hours, the culture medium was removed, gels rinsed once with PBS without $\mathrm{Ca}^{2+}$ and $\mathrm{Mg}^{2+}$ and the cell associated factor $\mathrm{X}$ and $\mathrm{Xa}$ activity was measured as follows (Van Dam-Mieras et al.1992):

\section{Factor $X$.}

Per well 25 il RVV (Russell's Viper Venom; I vial containing $1 \mathrm{mg}$ factor X activating protein in $0.1 \mathrm{mmol} / \mathrm{I} \mathrm{NaCl}$, dissolved in $15 \mathrm{ml}$ destilled water $), 25 \mu \mathrm{l}$ trisbuffer $(0.05$ $\mathrm{mol} / \mathrm{l}, 20 \mathrm{mg} / \mathrm{l}$ polybrene, $\mathrm{pH} 7.8)$ and $25 \mu \mathrm{l} \mathrm{CaCl}(0.01 \mathrm{~mol} / \mathrm{l})$ are added and the mixture is incubated for 15 minutes at $37^{\circ} \mathrm{C}$. Then $50 \mu \mathrm{l}$ of the chromogenic substrate \$2337 (1 vial containing $30 \mu \mathrm{mol} / 1$ dissolved in $20 \mathrm{ml}$ destilled water) is added to the well. After 60 minutes incubation at $37^{\circ} \mathrm{C}$ citric acid GR $(4 \%)$ is added and extinction measured at $405 \mathrm{~nm}$. Arbitrarily

$100 \mathrm{IU} / \mathrm{ml}$ is defined as the amount of factor $\mathrm{X}$ corresponding the absorption value of 1.000 . This unit will be used in the other amidolytic assays as well.

Factor $\mathrm{X} a$.

Per well $50 \mu \mathrm{l}$ tris buffer $(0.05 \mathrm{~mol} / \mathrm{l}, 20 \mathrm{mg} / \mathrm{l}$ polybrene, $\mathrm{pH} 7.8)$ and $25 \mu \mathrm{l} \mathrm{CaCl}_{2}$ $(0.01 \mathrm{~mol} / \mathrm{l})$ are added and the mixture is incubated for 15 minutes at $37^{\circ} \mathrm{C}$. Then $50 \mu \mathrm{l}$ of the chromogenic substrate $\$ 2337$ (1 vial containing $30 \mu \mathrm{mol} / 1$ dissolved in $20 \mathrm{ml}$ destilled water) is added to the well. After 60 minutes incubation at $37{ }^{\circ} \mathrm{C} 25 \mu \mathrm{l}$ citric acid GR (4\%) is added and the extinction measured at $405 \mathrm{~nm}$.

Inhibition of factor $X / X a$ by an anti-X antibody.

To identify factor $X$, an antibody against Factor $X$ (anti-human coagulation factor $X$ of the CLB, Amsterdam, the Netherlands, anti-human coagulation factor $X$, Behring, Germany and anti-bovine coagulation factor $X$, University of Limburg, Dept. Biochemistry, Maastricht, the Netherlands) $(0.1 \mathrm{IU} / \mathrm{ml})$ was added to the aggregates 60 minutes prior to the amidolytic assay. Absorption was measured at $405 \mathrm{~nm}$. These antibodies were used since they inhibited both human as well as bovine factor $\mathrm{X} / \mathrm{Xa}$.

To further study the cell associated factor X-like amidolytic activity, the inhibitors $\mathrm{HgCl}_{2}$ $(0.1 \mathrm{mM})$, Iodoacetamide $(1 \mathrm{mM})$ are used. The endothelial cells were incubated with $\mathrm{HgCl}_{2}$ or Iodoacetamide for 30 minutes prior to the amidolytic assay with $\mathrm{S} 2337$, and absorption measured at $405 \mathrm{~nm}$.

\section{Chromogenic determination of Factor VII.}

To determine whether tissue factor was responsible for factor $\mathrm{X} / \mathrm{Xa}$ expression, we used a previously described assay (Van Dam-Mieras et al.1992). This assay is based on the dependency of factor VII activity on tissue factor. The assay, using chromogenic substrate S2765 was carried out as described by the manufacturer (COA-Set FVII, KabiVitrum, Amsterdam, the Netherlands), with adapted incubation times for the collagen gels (incubation times are doubled).

In vitro cocultures of endothelial and tumor cells in separate compartments.

In order to verify that the procoagulant vesicles were indeed originating from the endothelial cells, the following assay was performed. Endothelial cells were cultured in 6well culture plates until confluency. In each well an insert $(0.45 \mu \mathrm{m}$, Falcon, Becton and 
Dickinson BV, Etten-Leur, the Netherlands) was placed in which HT29 tumor cells were grown. Tumor cells were not able to pass through the pores within 24 hours. At different time intervals the cocultures were evaluated for the formation of vesicles.

Similarly, endothelial cell monolayers were incubated with conditioned medium from the tumor cells and evaluated for the occurrence of vesicles.

\section{Statistics.}

Statistical analyses were performed by using the Wilcoxon Mann Whitney test.

\section{Results.}

Endothelial cell aggregates (BCE cells) showed sprout formation when cultured in collagen type I gel in the presence of Donor Calf Serum, as has been described by Montesano (Montesano 1992). This model developed by Montesano is a valid in vitro model for studying angiogenesis (figure 1).

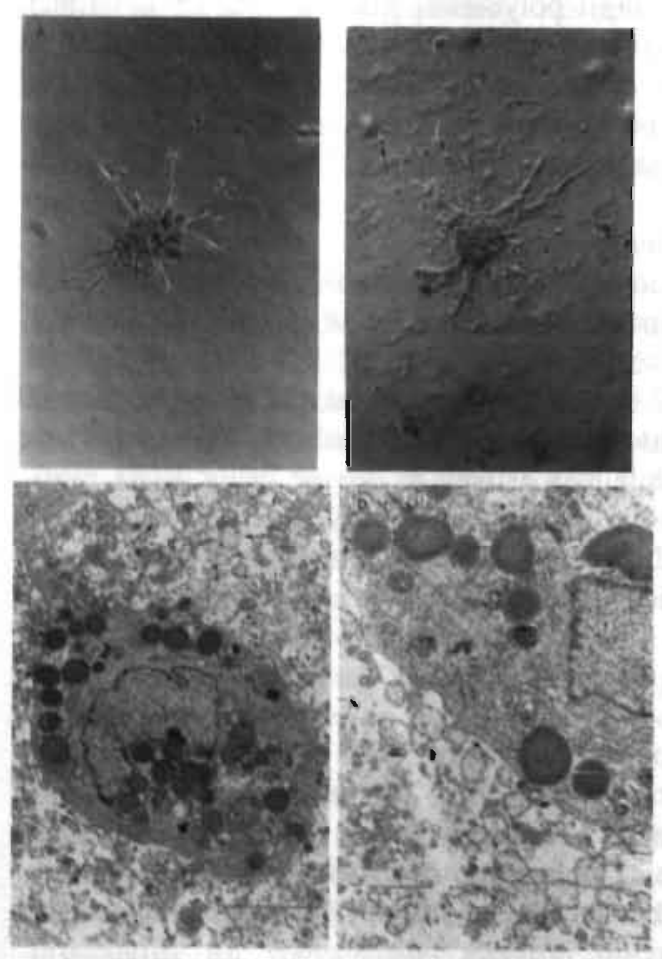

Figure 1. la) Sprouting ondothelial (BCE) aggregates in collagen type I matrix and Ib) sprouting endothelial aggregatos cocultured with HT29 tumor spheroids ( $t)(200 \mathrm{x}$ ).

1c) Ultrastructural micrographs show numerous microvesicles ( $\uparrow$ ) on endothelin! sprouts cocultured with tumor spheroids, with loss of the endothelial cell integrity $(8.050 \mathrm{x})$.

Id) Vesicles are shed from the endothelial cell membrane ( $\uparrow)(18.550 \mathrm{x})$. 
When endotheliai cells and tumor cells were co-cultured in the collagen gel, extracellular vesicle-like stuctures were found on the endothelial sprouts (figure $1 \mathrm{~b}, \mathrm{c}, \mathrm{d}$ ). No vesicles could be observed on the control sprouts, which is in agreement with the results of Montesano. The vesicles; are fairly large $(0.5-2 \mu \mathrm{m})$ and showed a remarkable resemblance to the procoagulant vesicles formed upon stimulation of erythrocytes and thrombocytes with, for instance, a calciumionophore (Schroit \& Zwaal 1991). The latter are known to display a procoagulant character, most probably due to perturbations in the asymmetric phospholipid distribution in the membrane. We therefore investigated whether the vesicles, induced on endothelial sprouts upon coculturing with tumor cells, exhibited procoagulant characteristics. We argued that, as serum (which is a source for coagulation factors like factor $\mathrm{X}$ ), is present in culture media, the formation of a procoagulant surface would most probably lead to the binding of coagulation factors to that cell surface and therefore we decided to search for a procoagulant effect using S2337, a chromogenic factor $\mathrm{X}$ substrate. The results of the factor $\mathrm{X}$ and factor $\mathrm{Xa}$ assays are summarized in figure 2 .

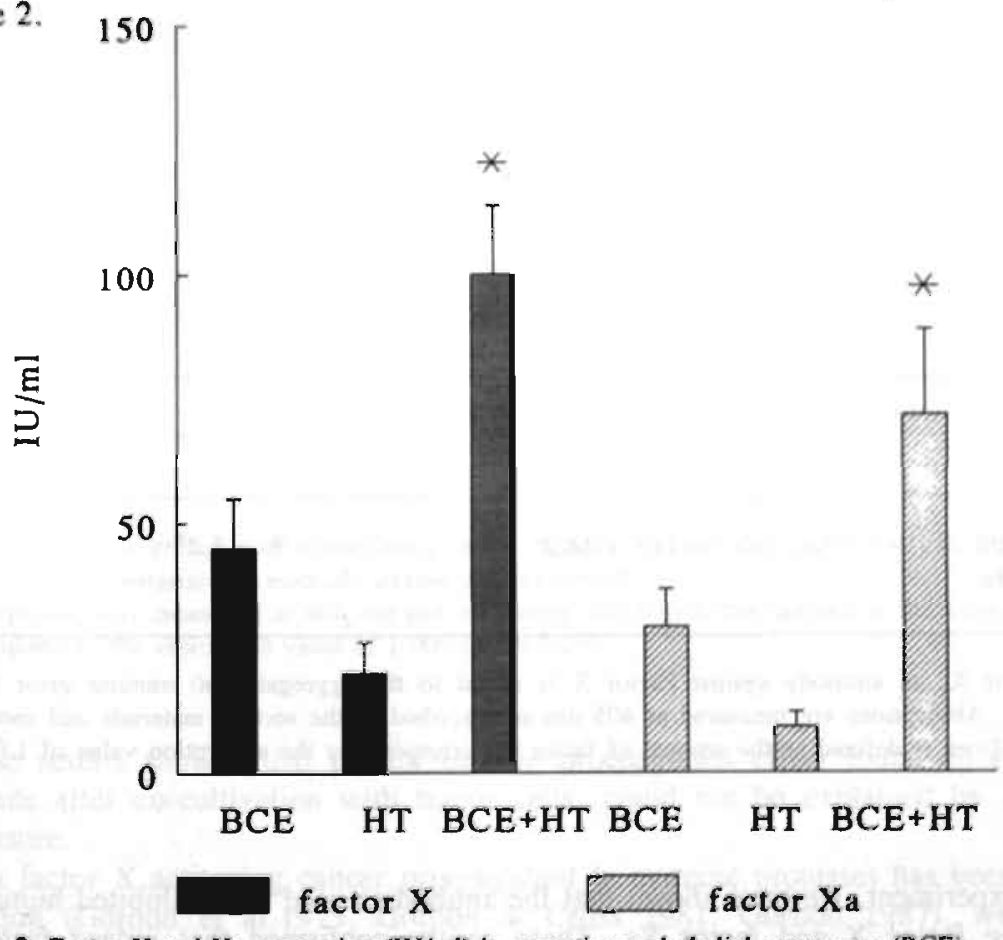

Figure 2. Factor $\mathrm{X}$ and $\mathrm{Xa}$ expression (IU/ml) in sprouting endothelial aggregates (BCE) cocultured with HT29 tumor spheroids (BCE + HT29) as described in the section materials and methods, show an increase in both factor $\mathrm{X}$ and factor $\mathrm{X}$ a expression $(* \mathrm{P}<0.001)$.

Tumor cells alone in vitrogen did not exceed the control values of BCE aggregates $(n=40)$. 
Upon measurement of both $\mathrm{X}$ and $\mathrm{Xa}$, a significant $(\mathrm{P}<0.001)$ increase of factor $\mathrm{X} / \mathrm{Xa}$ expression was found for endothelial aggregates co-cultured with tumor cells. The amidolytic activity, displayed after coculture of endothelial and tumor cells, was more than the sum of the individual values from the endothelial cell aggregate cultures and the tumor cell cultures (figure 2). Thus apparently co-culturing of endothelial cell aggregates with tumor cells resulted in a potentiated increase in amidolytic activity suggestive of factor $\mathrm{X} / \mathrm{Xa}$.

To investigate whether the vesicles indeed were originating from the endothelial cells we also studied the effect of cocultivation, using separate compartments, for endothelial and tumor cells. Also in this separate compartment system vesicle formation occurred on the endothelial cells after exposure to HT29 tumor cells. Tumor conditioned medium alone did not induce vesicle formation.

Addition of anti-factor $\mathrm{X}$ antibody, prior to testing for amidolytic activity, completely blocked the factor $\mathrm{X} / \mathrm{Xa}$-like activity (table 1 ).

Table 1. Identification of factor $X$ with an anti-X antibndy.

Factor $\mathrm{X}$

expression
BCE sprouts
$45 \pm 11.8$
$2 \pm 1.9^{\prime}$
BCE sprouts with
$113 \pm 18.2$
$5 \pm 3.2^{\prime}$

HT29 tumor cells

To identify factor $X$, an antibody against Factor $X$ is added to the aggregates 60 minutes prior to the amidolytic assay. Absorptions are measured at $\mathbf{4 0 5} \mathrm{nm}$ as described in the section materials and methods. Arbitrarily $100 \mathrm{IU} / \mathrm{ml}$ is defined as the amount of factor $\mathrm{X}$ corresponding the absorption value of 1.000 ("f $P<0.05$ ).

In a control experiment, we have shown that the antibodies used here inhibited human as well as bovine factor $\mathrm{X}$ and factor $\mathrm{Xa}$. These results confirmed that indeed factor $\mathrm{X}$ activity was measured in the amidolytic assay.

We then investigated if tissue factor exposure could explain the procoagulant activity on endothelial sprouts. Tissue factor activity was assayed by a chromogenic factor VII assay. The assay is based on the dependency of factor VII activity on tissue factor. Complex 
formation between tissue factor and factor VII results in factor VII activation and subsequently this complex activates factor $\mathrm{X}$ either directly on indirectly via factor IX activation. Table 2 demonstrates that, when exogenous tissue factor was added to the system, almost no factor VII activity was found, neither on the collagen nor on the different cell types. Upon addition of tissue factor a similar factor VII activity was found in all experiments.

Table 2. Chromogenic activity recorded in the factor VII assay.

$\begin{array}{ll}\text { With } & \text { Without } \\ \text { thromboplastin } & \text { thromboplastin } \\ \text { addition } & \text { addition } \\ (\mathrm{IU} / \mathrm{ml}) & \text { (IU/ml) }\end{array}$

Collagen gel

$10 \pm 2.8$

$1+1.8$

BCE sprouts without

$13.5+4.1$

$1 \pm 1.9$

HT29 tumor cells

HT29 tumor cells in

$8 \pm 3.2$

$0.8+1.8$

collagen gel

BCE sprouts with

$14.6 \pm 4.9$

$0.9 \pm 2.1$

HT29 tumor cells

To determine the presence of tissue factor in the cultures, the two-step factor VII/VIla amidolytic assay as outlined in the material and methods section was performed.

Absorptions were measured at $405 \mathrm{~nm}$ and arbitrarily $100 \mathrm{IU} / \mathrm{ml}$ was defined as the amount of fuctor VIla corresponding the absorption value of 1.000 ( $\# \mathbf{P}<0.05$ ).

These results showed that the increase in procoagulant effect found on endothelial cell sprouts after co-cultivation with tumor cells, could not be explained by a tissue factor exposure.

As a factor $\mathrm{X}$ activating cancer procoagulant (a cysteine protease) has been described by Gordon (Gordon et al.1975, Gordon \& Cross 1981, Gordon 1987), we subsequently studied the effect of incubating endothelial aggregates with $\mathrm{HgCl}_{2}$ and lodoacetamide prior to the assay of factor $\mathrm{X}$ activity. Both the factor $\mathrm{X}$ and $\mathrm{Xa}$ expression were significantly inhibited by these compounds (figure 3); which indicated that the binding to the surface seemed to be dependent on the availability of - $\mathrm{SH}$-groups. 


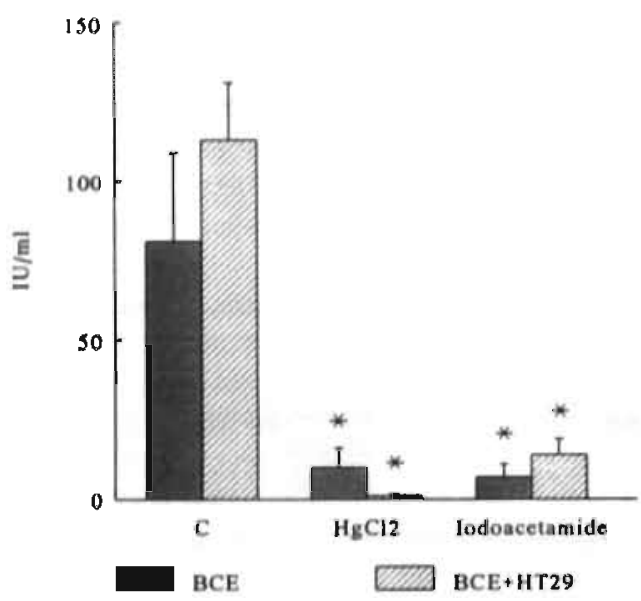

a

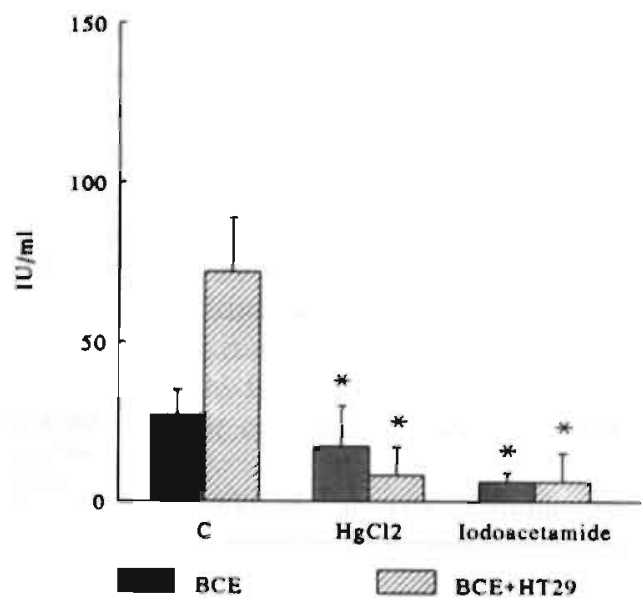

b

Figure 3. 3a) Significant ( $* \mathrm{P}<0.05$ ) inhibition by $\mathrm{HgCl}_{2}$ and lodoacetamide of factor $\mathrm{X}$ expression and $3 b$ ) factor $\mathrm{Xa}$ expression on endothelial cell aggregates with or without cocultured tumor spheroids as in the previous figure.

The results do not point in the direction of a cancer procoagulant activity, as was confirmed by Gordon (personal communication, 1993).

\section{Discussion.}

Upon stimulation with HT29 tumor cells, the endothelial cells formed sprouts on which vesicle-like structures were seen. In order to verify whether these vesicles were indeed originating from the endothelial cell, we also studied the effect of cocultivation, using separate compartments for endothelial and tumor cells. The results confirmed the vesicles were originating from the endothelial cells. However an additional effect was seen. In order to obtain vesicle formation the presence of the tumor cells were required although direct contact with the endothelial cell was not necessary. This suggested two possibilities. Either a highly instable factor is continuously generated by the tumor cells or a component that needs the presence of the tumor cell in order to exert its activity, is synthesized by these tumor cells. Further experiments on this will be needed to elucidate this. The formation of these extracellular microvesicles on endothelial cell sprouts induced by tumor cells in vitro, has not been described before, although vesicles shed by tumor cells themselves have been described. However, these vesicles are much smaller than the vesicles we observed (Dvorak et al.1983, Falanga \& Gordon 1985, Gordon et al.1975, 
Gordon \& Cross 1981, Gordon 1987, Gordon \& Mourad 1991). The endothelial derived vesicles 'resembled the vesicles that can be formed upon activation by erythrocytes and thrombocytes. The formation of these vesicles has been associated with stimulatory events that induced a change in the asymmetric distribution of phospholipids over the inner and outer leaflet of the plasma membrane. Because of these membrane perturbations these vesicles are procoagulant in nature (Schroit \& Zwaal 1991).

Our experiments using the factor $\mathrm{X} / \mathrm{Xa}$-like activity assay would lend support for the procoagulant nature of the vesicles on endothelial sprouts and it is tempting to speculate that also here membrane perturbations are involved. The observation that an anti-factor $\mathrm{X}$ antibody completely blocked factor $\mathrm{X}$ activity shows that our assay specifically measured factor $\mathrm{X} / \mathrm{Xa}$.

We first investigated if tissue factor exposure is involved, by using the two-stage assay for factor VIla. The results showed that the observed effect could not be explained by tissue factor exposure. We then investigated if our results could be explained by a cancer procoagulant, described to be present in several tumor cell types, among which HT29 (Gordon 1987). This cancer procoagulant is a cysteine protease, having $\mathbf{S H}$-groups in the catalytic site. It directly activates factor $\mathrm{X}$ without the involvement of the factor VII/Tissue Factor complex (Gordon \& Mourad 1991). However, the results with the SHinhibiting reagents $\mathrm{HgCl}_{2}$ and lodoacetamide indicated that cancer procoagulant did not provide a straight forward explanation for our results since not only Xa expression was significantly reduced after addition of $\mathrm{HgCl}_{2}$ or Iodoacetamide but factor $\mathrm{X}$ expression as well. This points to an inhibiting effect of $\mathrm{SH}$-modification on the interaction of factor $\mathrm{X} / \mathrm{Xa}$ with the endothelial cell surface. Further experiments will be needed to elucidate the underlying mechanisms of this phenomenon.

In vivo findings support the hypothesis that procoagulant activity leading to fibrin formation not only supports haemostasis but is a relevant abnormality in malignant growth (Trouseau 1885, Bick 1992, Donati et al.1981, Gordon 1987, Paku \& Paweletz 1991, Carty et al.1992). In many malignant situations the intravascular coagulation syndrome only is manifested at local levels and does not lead to clinically manifest symptoms. Both the hidden coagulation abnormalities and the role fibrin seems to play in tumor growth and metastasis, emphasizes the importance of in vitro studies on tumor cell-endothelial cell interactions regarding haemostatic abnormalities. In turn, this could lead to better interventions in treating malignancies.

\section{Acknowledgement.}

The authors thank Mr. M. Stuart of the Electron Microscopic Unit, department of pathology for his excellent work in preparing the ultrastructural micrographs.

\section{References.}

Altier DC, Edgington TS. The saturable high affinity association of factor $\mathrm{X}$ to ADP-stimulated monocytes defines a novel function of the MAC-1 receptor. J. Biol. Chem. 263, 7007-7015, 1988. 
Bick RL. Coagulation abnormalities in malignancy: a review. Sem. Thromb. Hemostas. 18, 4, 353-379. 1992.

Carty NJ, Taylor I, Roath OS, El Baruni K, Francis JL. Tissue procoagulant activity may be important in sustaining metastatic tumour growth. Clin. Exp. Metast. 10(3), 175-181, 1992.

Donati MB, Poggi A, Semeraro N. Coagulation and malignancy. In: Recent advances in blood coagulation. Poller L. Editor, Churchill Livingstone, New York, 375-391, 1981.

Dvorak H, Van de Water L, Bitzer A, Dvorak A, Anderson D, Harvey V, Bach R, Davis G, DeWolf W, Carvalho A. Procongulant activity associated with plasma membrane vesicles shed by cultured tumor cells. Cuncer Res. 43(9), 4334-4342, 1983.

Dvorak HF, Harvey VS, Estrella P, Brown L, McDonach J, Dvorak AM. Fibrin containing gels induce angiogenesis. Implicalions for tumor stroma generation and wound healing. Lab. Invest. 57, 673, 1987.

Falanga A, Gordon S. Isolation and characterization of cancer procoagulant: a cysteine proteinase from malignant tissue. Biochem. 24, 5558-5567, 1985.

Fogh J, Fogh JM, Orleo T. One hundred and twenty seven cultured human tumor cell lines producing tumors in nude mice. J. Natl. Cancer Inst. 59, 221-226, 1977.

Folkman J. What is the evidence that tumors are angiogenesis dependent? J. Natl. Cancer Inst. 82(1), 4-6, 1990.

Gordon SG, Franks JJ, Lowis B. Cancer procoagulant A: a factor X activating procoagulant from mulignant tissue. Thromb. Res, 6, 127, 1975.

Gordon SG, Cross BA. A factor X-activating cysteine protease from malignant tissue. J Clin Invest, 67. 1665-1671, 1981.

Gordon SG. Cancer Procoagulant. In: Hemostasis and Cancer. Laszlo Muszbek Editor, CRC Press Inc. Boca Raton, Florida; 4-14, 1987.

Gordon SG, Mourad AM. The site of activation of factor $X$ by cancer procoagulant. Blood Coagul. Fibrinolysis. 2 (6), 735-739, 1991.

Lichtenbeld HC, Blijham GH. Tumor cell spheroids induce a mitogenic response in endothelial cells. In: Angiogenesis: Koy principles, Science, Technology. Medicine. R. Steiner, PB Weisz, R. Langer, Eds. Birkhiuser Verlag Basel, 261-265, 1992.

Machovich R. Role of blood coagulation-fibrinolytic system and endothelial cells in malignancy. In: Hemostasis and cancer. Laszlo Muszbek Editor, CRC Press Inc. Boca Raton, Florida; 4-14, 1987.

Montesano R. Regulation of angiogenesis in vitro. Eur. J. Clin. Invest. 22, 504-515, 1992.

Paku S. Paweletz N. First steps of tumor-related angiogenesis. Lab Invest 65(3), 334-346, 1991.

Schroit AV, Zwaal RFA. Transhilayer movement of phospholipids in red cell and platelet membranes. Biochem. Biophys. Acta 107, 313-324, 1991. 
Trousseau A. Phlegmatia Alba Dolens: Clinique Médicale de I'Hôtel Dieu de Paris, tome troisième, Librairie J.B. Bailtière: et Fils, Paris, 695-705, 1885.

Van Dam-Mieras MCE, Muller AD, Van Hinsbergh VWM, Mullers WJHA, Bomans PHH, Bruggeman CA. The procoagulant response of cytomegalovirus infected endothelial cells. Thromb. Haemostas. 68(3). 364-370, 1992. 



\title{
Chapter 5.
}

\section{Lipid peroxidation of cells; a possible mechanism in tumor angiogenesis?}

\begin{abstract}
.
It has been postulated that coagulation and fibrin formation could be benificiall for tumor growth. since it is thoughe that fibrin provides provisional matrix in which the tumor can grow and develop its vascular network (Dvorak et all. Lab Invesi 57673 1987). The development of a vascular network is essential for the succesful growth of the fumot (Folkman J Natl Cancer Inst 82(1) 4 1990). Furthermore, fibrin could possibly protect the tumor from host defense mechanisms. Previously we found that tumor cells stimulated endothelial cell proliferation. promoted the formation of membrane vesicles and increased the procoagulant response of endothetiall cells (Lichtenbeld \& Blijham, Angiogenesis, Birkhăuser Verlag Basel 1992; Lichtenbeld et al. 1993 submitted).

An intruiging aspect of tumors is their production of relatively large amounts of reactive oxygen species (Szatrowski \& Nathan Cancer Res 51 794-798 1991). Reactive oxygen species are considered to be involved in reversible and irreversible cell damage of, among others, the endothelial cell. Endothelial cells are good targets for reactive oxygen species, since they have. relatively large amounts of polyunsaturated fatty acids (PUFA) in their cell membrane and an low catalase activity (catalase is one of the main defence mechanisms against reactive oxygen species). To investigate if reactive oxygen species might be involved in the endothelial cell response to tumor cells, we introduced peroxides (hydrogenperoxide and tert-butyl-hydroperoxide) to our in vitro model. We examined the proliferative behavior of endothelial cells using the bromodeoxyuridine incorporation assay. Morphological changes were evaluated with light- and electronmicroscopy and the procoagulant response was evaluated via factor $\mathrm{X} / \mathrm{X}$ a expression using chromogenic substrate $\mathbf{2 3 3 7 .}$.

The results indicated that peroxide treatment of endothelial cells inhibited cell proliferation, promoted the formation of membrane vesicles and increased the procoagulant response. The effects could he modified by the radical scavenger $\alpha$-tocopherol (vitamin E). These results suggest that reactive oxygen species could be involved in the endothelial cell ieponse to tumors.
\end{abstract}

\section{Introduction.}

The angiogenic phenomenon, which is essential for the succesful growth of tumors involves the switch of the avascular tumor nodule to the angiogenic phenotype (Folkman 1990, Folkman et al.1989). Tumors need to switch to this phenotype in order to establish the interaction with the host vasculature that will induce their vascular network. For the formation of bloodvessels, endothelial cells from host vessels are recruited (Blood \&. Zetter 1990), but the mechanism that underlies this recruitment largely remains to be elucidated. It is to be expected that more than one mechanism contributes to this angiogenic phenomenon (Rastinejad et al.1989, Kandell et al.1991, Folkman 1991, Burgess \& Maciag 1989, Klagsbrun \& D'Amore 1991, Goldfarb 1990, Roberts et al.1986, Leibovich et al.1987, Leung et al.1989) and probably many cell types will be involved.

Another intruiging, at first sight unrelated aspect of tumors, is the production of relatively large amounts of reactive oxygen metabolites, a.o. hydrogen peroxides (Szatrowski \& 
Nathan 1991, Voest et al.1992). Reactive oxygen species are considered to be involved in reversible and irreversible cell injury (for a review see Dargel 1992 and Halliwel et al.1992). They can cause cell injury either directly or indirectly by generating secondary oxygen metabolites like hydroxyl radicals $(\mathrm{OH} \cdot)$, hypochloric acid $(\mathrm{HOCl})$, chloramines $\left(\mathrm{RNH}_{2} \mathrm{Cl}\right)$ and lipid hydroxyperoxides (Halliwel et al.1992, Harris et al.1992). Once a cell, for instance the endothelial cell, is subjected to oxidative stress from another cell, for example a tumor cell, several defence mechanisms will scavenge or detoxify the reactive oxygen species (Harris et al.1992, Hiraishi et al.1992). These comprise free radical scavengers (i.e. vitamin $\mathrm{E}$ ), ion binding proteins, the glutathione redox cycle and endogenous catalase or superoxide dismutase. However, a tumor which continuously generates oxidants will finally exhaust the detoxifying capacity of the endothelial cell and cell damage will result.

To investigate if oxygen metabolites may be involved in tumor angiogenesis, we introduced exogenous oxidative stress to in vitro cultured endothelial cells. We cultured endothelial cells, exposed them to oxidants and studied their proliferative behavior, morphological changes and expression of factor X/Xa (Van Dam-Mieras et al.1992). The results indicated that oxidant treatment of endothelial cells inhibited cell proliferation, whereas it promoted the formation of membrane vesicles and increased the procoagulant response of endothelial cells. As we observed similar changes in vesicle formation and procoagulant activity after exposure of endnthelial cells in tumn. rells Tishtentold ot. al.1993), the present results suggested that reactive oxygen species might be involved in tumor induced angiogenesis.

Materials and Methods.

Chemicals.

Tert-butyl hydroperoxide (t-buOOH) and $d \cdot \alpha$-tocopherol-acetate type III (Vitamin E) were purchased from Sigma Chemical Company, St.Louis MO, USA. Hydrogen peroxide $\left(\mathrm{H}_{2} \mathrm{O}_{2}\right)$ were obtained from Merck, Darmstadt, Germany.

\section{Endothelial cell isolation and culture.}

Human umbilical vein endothelial cells (HUVEC) were isolated according to a modification of the method of Jaffe (Jaffe et al.1973). The cells were cultured in fibronectin (Central Laboratory of the Netherlands Red Cross Transfusion Service CLB, Amsterdam, the Netherlands) precoated 6-wells culture dishes (Costar. Badhoevedorp, the Netherlands). Growth medium consisted of $40 \%$ Medium 199 (Gibco, Paisly UK). 40\% RPMI1640 (Gibco, Paisly UK), and 20\% human serum (Bloodbank Academic hospital Maastricht, the Netherlands). Crude endothelial cell growth extract purified according to Maciag (Maciag et al. 1979) and Gentamycin $(50 \mu \mathrm{g} / \mathrm{ml})$ were supplemented as well. Cells were used in the third or fourth passage at confluency.

Bovine Capillary endothelial cells (BCE) were kindly provided by Dr. M Furie (University of Stony Brook, Dept. Pathology, Stony Brook NY, USA) and routinely cultured on gelatin precoated 6-wells culture dishes in Minimal Essential Medium, $\alpha$ modification ( $\alpha-$ MEM) (Gibco) supplemented with $15 \%$ Donor Calf Serum (DCS) (Flow, Irvine Scotland). Cells were used between passage 15 and 18 . 
Endothelial monolayer cultures and manipulations.

HUVEC and BCE cells were cultured in 6-wells culture dishes as described above until confluency. Cells were washed with phosphate buffered saline without: $\mathrm{Ca}^{2+}$ and $\mathrm{Mg}^{2+}$ (PBS). Serum free medium (RPMI1640 or Hanks Balanced Salt Solution (HBSS) for HUVEC and $\alpha$-MEM for BCE cells) was added, supplemented with t-buOOH or $\mathrm{H}_{2} \mathrm{O}_{2}$ (250 $\mu \mathrm{mol} / 1$ or $25 \mu \mathrm{mol} / 1$ final concentrations respectively). Alternatively cells were cultured with vitamin E $(250 \mu \mathrm{mol} / 1 \mathrm{~d}-\alpha$-tocopherol) for at least 24 hours (Patel et al. 1991), subsequently followed by treatment with peroxides.

\section{Mophological studies: light microscopy and scanning electron microscopy.}

The endothelial cell monolayer cultures were examined under a phase contrast microscope and photographs were taken $(250 \mathrm{x})$. Then the cultures were fixed in $2.5 \%$ glutaraldehyde and processed according to standard procedures for scanning electron microscopy. Briefly, the fixed monolayers were dehydrated in graded alcohol, immersed in $100 \%$ ethanol and dried by the critical-point method. The samples were sputtercoated with gold and micrographs taken with a Philips CM12 scanning microscope using secondary electrons.

\section{Proliferation of endothelial cells.}

Proliferation rate was measured by using the modified bromodeoxyuridine assay as described previously (Lichtenbeld and Blijham, 1992).

Chromogenic determination of factor $X / X a$-activity.

After 24 hours, the cell associated factor $\mathrm{X}$ and $\mathrm{Xa}$ activity was measured on endothelial cell monolayers according to the procedure of Van Dam-Mieras (Van Dam-Mieras et al. 1992)

\section{Results.}

Previously, we found that endothelial cell aggregates cultured in a collagen matrix responded to cocultivation with tumor (HT29) spheroids by forming vesicle like structures on the endothelial sprouts. Endothelial cell monolayer cultures also responded to tumor cells with the formation of vesicle like structures (Lichtenbeld et al, 1993). Furthermore, it has been found that tumors generate relatively large amounts of peroxides (Szatrowski \& nathan 1991). In the experiments performed here, we investigated the possible role of peroxides in the induction of this endothelial cell response to tumor cells.

We added exogenously peroxides (tbuOOH or $\mathrm{H}_{2} \mathrm{O}_{2}$ ) to confluent endothelial monolayer cultures, either HUVEC or BCE. The addition of peroxides to these cultures resulted in the formation of membrane blebs and vesicle-like structures on the endothelial cells as shown in figure 1 . 

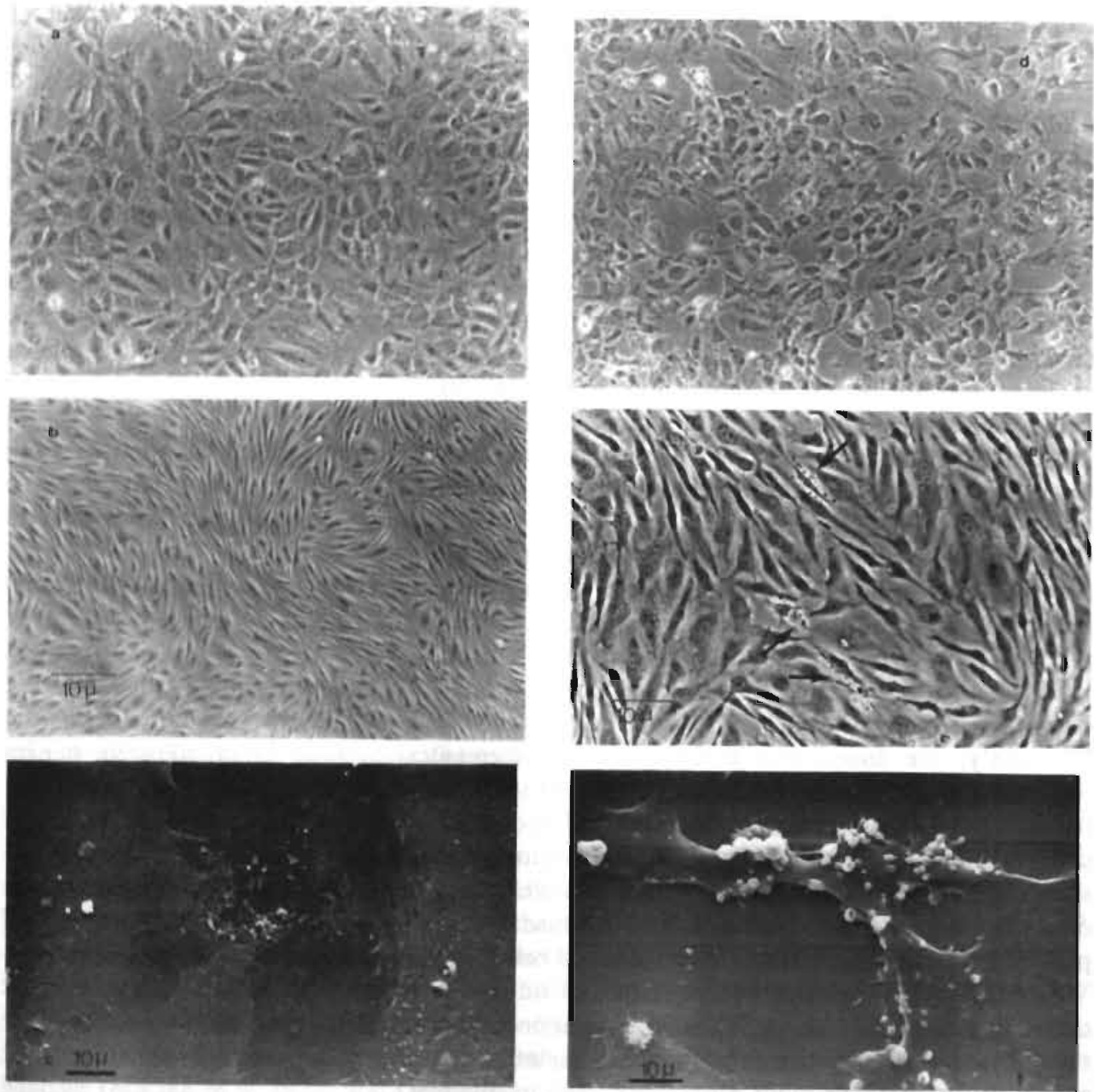

Figure 1. Light microscopic photographs of HUVEC (1a) and BCE (1b)i monolayers in culture foriginal magnification $\times 100$ ). Scanning electron micrograph of HUVEC (1c) monolayers (original magnification x1250).

After $30 \mathrm{~min}$ treatment with peroxide $(250 \mu \mathrm{mol} / 1)$, the endothelial cell membrane started hlebbing as shown in light microscopic photographs of HUVEC (Id) and BCEs (le) (original magnification resp, $\times 100$ and $200 x$ ) and scanning electron micrograph of HUVEC (II) (original magnification x1250). 
The vesicles probably fused during the next 24 hours since they became larger in size and less in number as shown in figure 2. The endothelial cells first started to loose their integrity after two hours of treatment and after 24 hours they had lost their integrity completely as can also be appreciated from figure 2 .

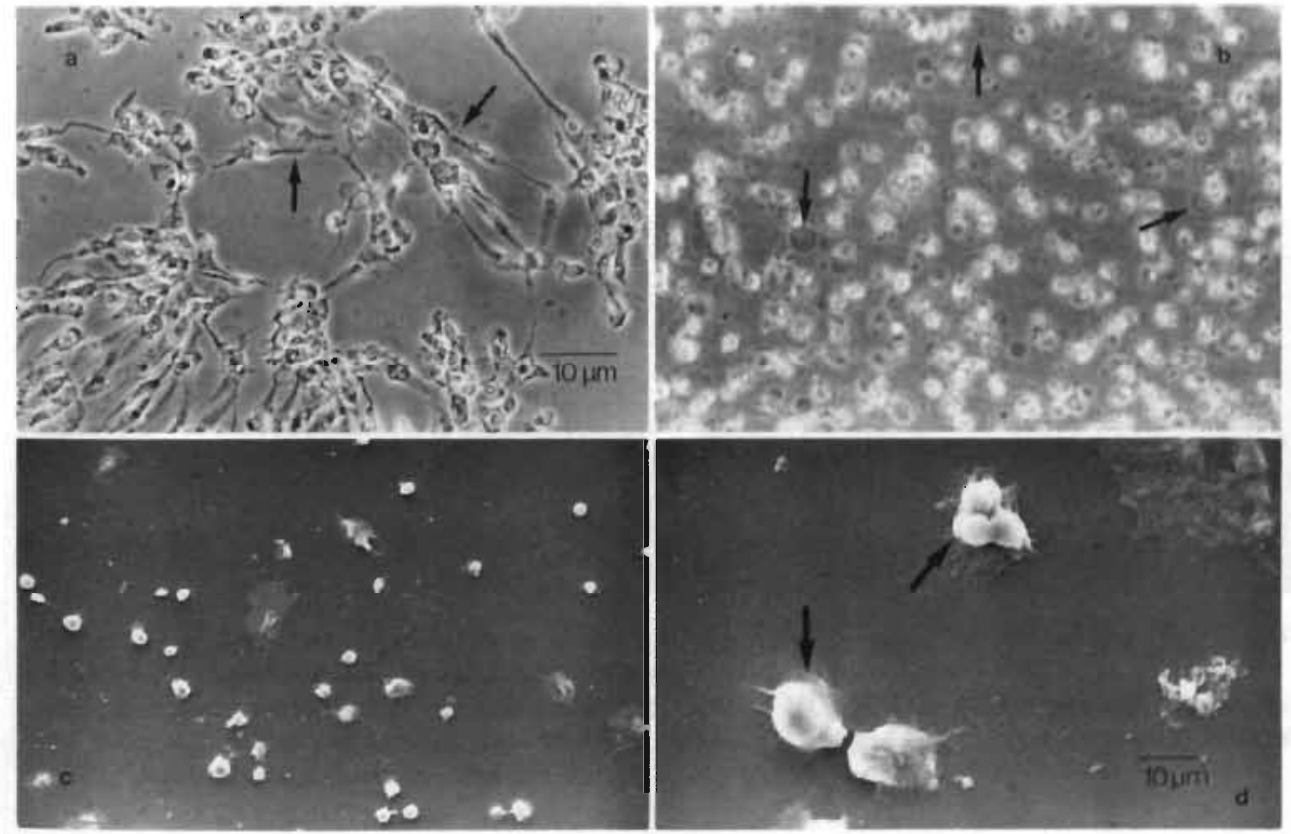

Figure 2. Light microscopic photograph of BCE (2a) and HUVEC (2b) (original magnification $\times 200$ ) treated with peroxides $(250 \mu \mathrm{mol} / \mathrm{l})$ for approximntely 20 hours, and scanning electron micrograph of peroxide treated HUVEC ( $2 c$ and $2 d$ ) (original magnifications resp. $312 x$ and $2500 x$ ) 
Trypan blue exclusion showed that most cells had died at this point. This was also confirmed by the proliferation rate of the treated endothelial cells which decreased from $2 \%$ when cultured in serum-free medium without peroxides to $0 \%$ after addition of peroxides $(250 \mu \mathrm{mol} / \mathrm{l})$ for 24 hours.

Vitamin E $(250 \mu \mathrm{mol} / \mathrm{l})$ pretreatment of endothelial monolayer cultures before the addition of peroxides $(250 \mu \mathrm{mol} / \mathrm{l})$ resulted in a slower formation of vesicles on the endothelial cells. Figure 3 shows the preventing effect of vitamin $E$ at this peroxide concentration (compare to figures $1 \mathrm{~d}, \mathrm{le}$ and $1 \mathrm{f}$ ). The preventive effect of vitamin $\mathrm{E}$ was only observed within the first hour and disappeared subsequently. 

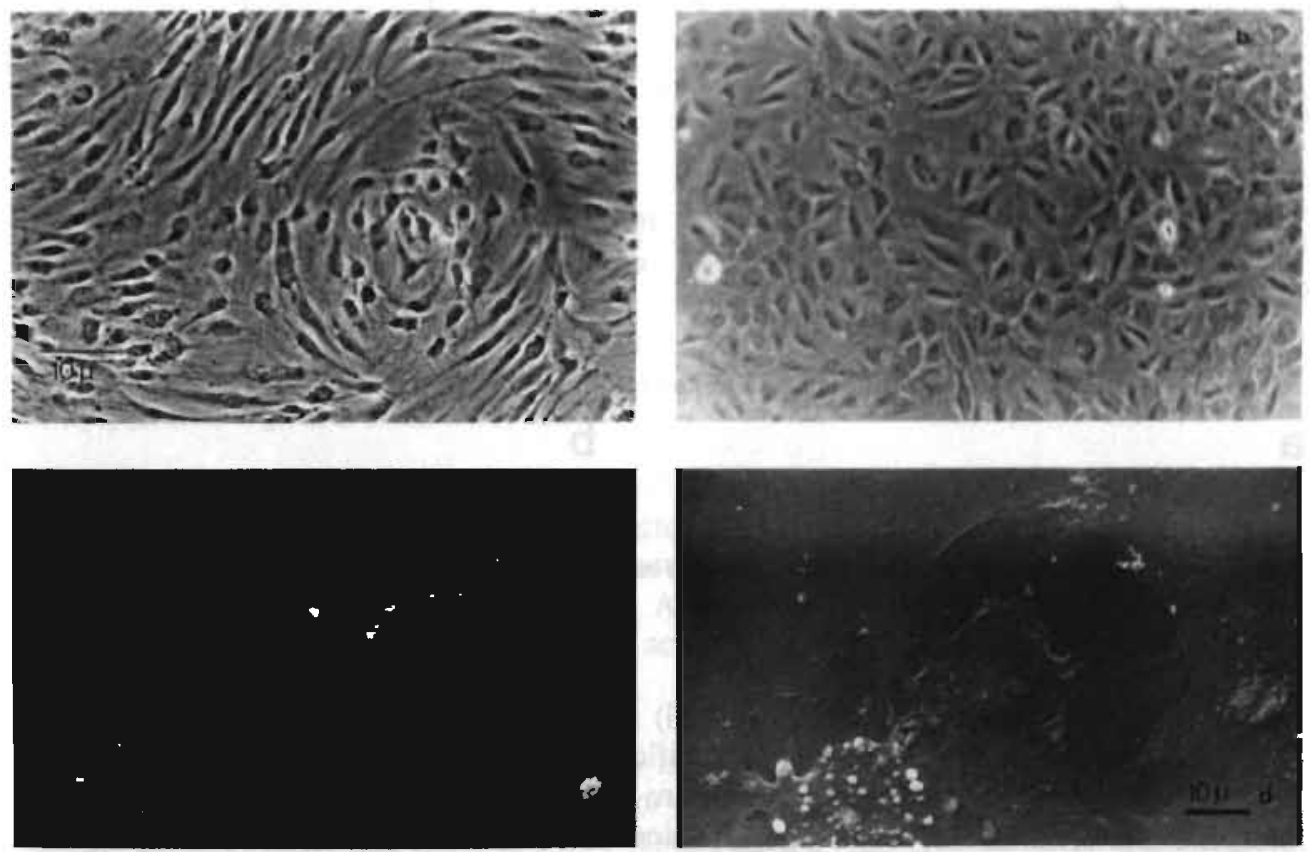

Figure 3. Light microscopic photographs of peroxide-treated (250 $\mu \mathrm{mol} / \mathrm{l})$ BCE (3a) and HUVEC (3b) cultures after vitamin $E$ preincubation (original magnification $\times 200$ ).

Scanning electron micrograph of peroxide-treated $(250 \mu \mathrm{mol} / \mathrm{I})$ HUVEC ( $3 \mathrm{c}$ and $3 \mathrm{~d}$ ) (original magnification resp. $312 \mathrm{x}$ and $1250 \mathrm{x}$ ) preincubated with vitumin E. Vitamin E reduced, but did not completely block the effect of peroxide treatmeat on endothelial cells. 
Previously, we also found an increase in the procoagulant response of endothelial cells after cocultivation with tumor cells (Lichtenbeld et al.1993). We therefore investigated whether exogenously added peroxides also resulted in a procoagulant response of the endothelial monolayer cultures. Figure 4 shows the results.

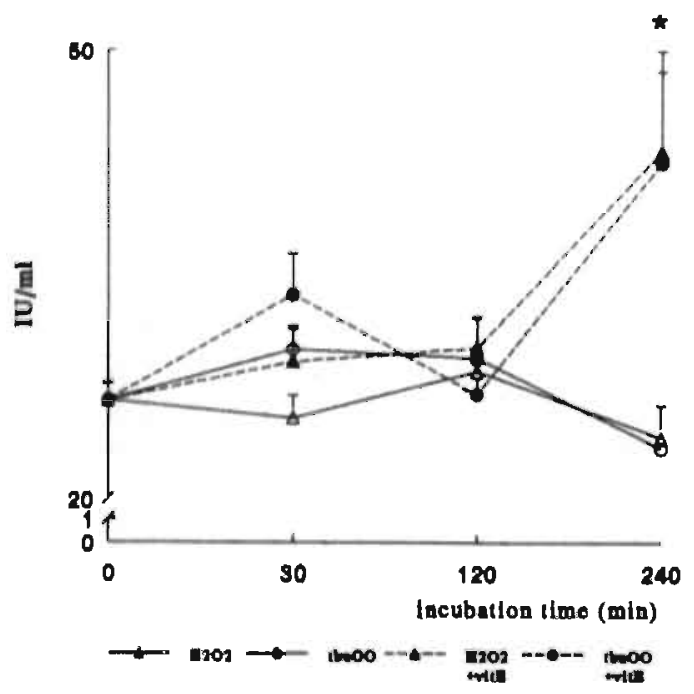

a

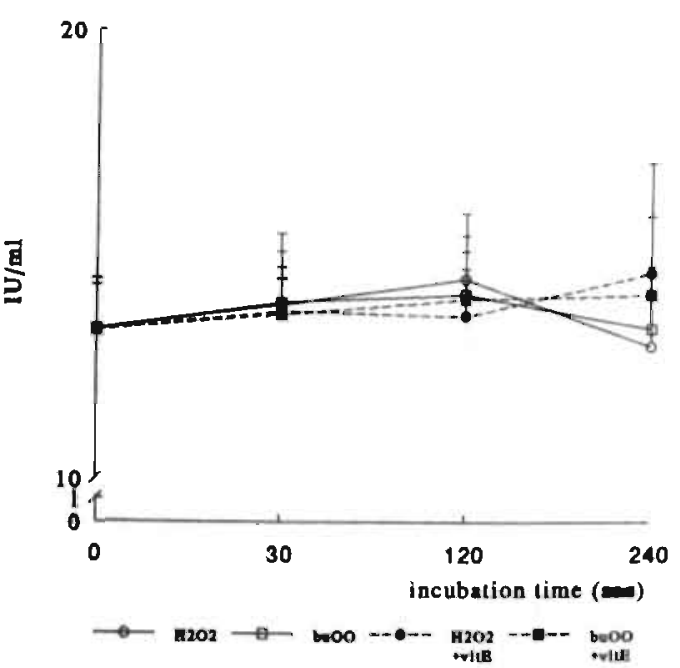

b

Figure 4. The expression of factor $X(4 a)$ and $\mathrm{Xa}(4 \mathrm{~b})$ on BCE cultures treated with tbuOOH or $\mathrm{H}_{2} \mathrm{O}_{2}(250 \mu \mathrm{M})$ is given 2 \& $a$ function of time.

High concentrations of peroxide $(250 \mu \mathrm{mol} / \mathrm{l})$ increased factor $\mathrm{X} / \mathrm{Xa}$ expression. After 2 hours, cells damage occurred, causing a significant decrease in the cell response, resulting in cell death. When the endothelial cells were cultured with vitamin E prior to peroxide treatment no effect on factor $\mathrm{X} / \mathrm{Xa}$ expression in the first 120 minutes was observed. However, vitamin $\mathrm{E}$ appeared to improve endothelial cell viability resulting in significant higher factor $\mathrm{X} / \mathrm{Xa}$ expression after 4 hours. Subsequently, we tested a lower dose of peroxides $(25 \mu \mathrm{mol} / \mathrm{l})$ in order to investigate a vitamin $E$ effect on the procoagulant response of not lethally damaged endothelial cells. Results are shown in figure 5. 


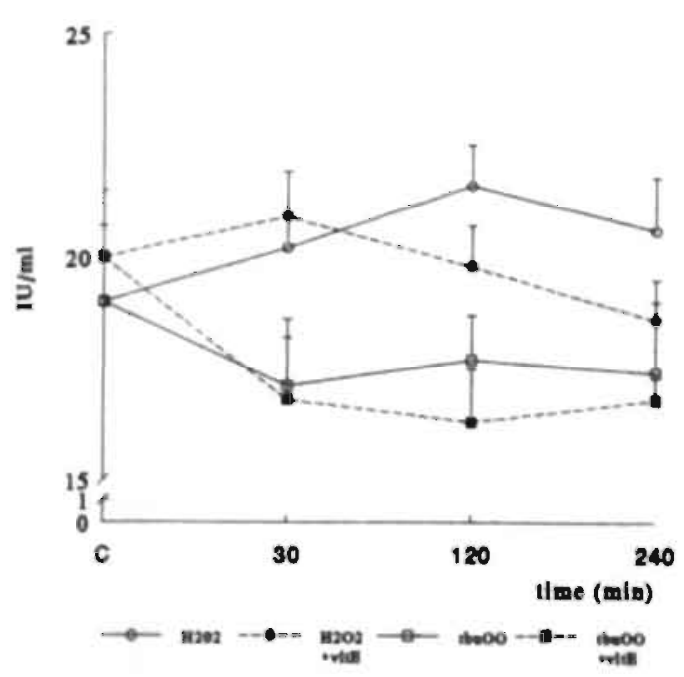

a

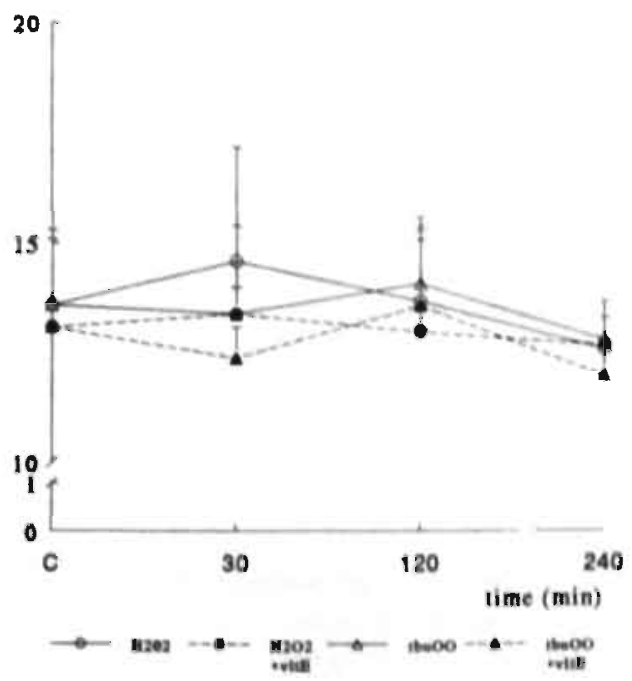

b

Figure 5. The expression of factor $X(5 a)$ and $\mathrm{Xa}(5 \mathrm{~b})$ on BCE eultures treated with tbuOOH or $\mathrm{H}_{2} \mathrm{O}_{2}(25 \mu \mathrm{M})$ is given as a function of time.

With $\mathrm{H}_{2} \mathrm{O}_{2}$ it appears that an increase of factor $\mathrm{X}$ expression could be induced that lasted for 4 hours and was inhibited by pretreatment of the endothelial cells with vitamin $E$; this difference was however not significant. A similar trend was observed in the Xa expression. Butylhydroperoxide seemed not active at this dose.

\section{Discussion.}

The objective of this study was to test the hypothesis that lipid peroxidation of the cell membrane could be a mediator in the tumor induced endothelial cell response. The idea behind this hypothesis was twofold. First, tumors have a high ATP turnover and therefore might easily generate oxidases, catalysing oxygen radical producing reactions (Harris et al.1992). It has indeed been found that tumors generate large amounts of hydrogen peroxides (Szatrowski \& Nathan 1991, Voest et al.1992) and thus tumor cells could easily affect endothelial cells by peroxidation of membrane phospholipids, proteins and DNA.

Second, endothelial cells have relatively large amounts of polyunsaturated fatty acids (PUFA) in their cell membrane which are good target molecules for reactive oxygen species. Furthermore, endothelial cells have a relatively low catalase activity, and contain high amounts of ferritin. Ferritin is an important iron source that plays a role in lipid peroxidation (Dargel 1992). These aspects make endothelial cells rather sensitive targets for peroxides. 
The results obtained here with the peroxides tbuOOH or $\mathrm{H}_{2} \mathrm{O}_{2}$ support the above described hypothesis. When endothelial cell monolayers were exposed to relatively high concentrations $(250 \mu \mathrm{mol} / \mathrm{l})$ of exogenous peroxides as was done in our experiments, the cell membrane started blebbing after 30 minutes, resulting in the formation of large, fused vesicles within 24 hours and cell death as confirmed with trypan blue exclusion. Vitamin E could delay the formation of vesicles on the endothelial cells for 1 hour, but after that extensive vesicle formation occured.

Cellular activation can result in vesicle formation as is described to occur in erythrocytes, thrombocytes and endothelial cells (Schroit \& Zwaal 1991). During the stimulatory events the asymmetric distribution of phospholipids in the cellular membrane is perturbed and therefore the resultant vesicles are procoagulant in nature. Membrane peroxidation may also result in similar perturbations and thus lead to formation of procoagulant vesicles.

The increased factor $\mathrm{X} / \mathrm{Xa}$ on the endothelial cells treated with peroxides supports this idea. However, more than two hours of treatment with $250 \mu \mathrm{mol} / 1$ peroxide was lethal for the endothelial cells. Vitamin E could protect the cells during a short time at this high concentration but it could not inhibit the expression of factor X/Xa.

We considered that the concentration of the peroxides used was too high to study its effect on factor $\mathrm{X} / \mathrm{Xa}$ expression and we therefore repeated the experiment with a 10 -fold lower dose. Now cells appeared to survive; the effects on the expression of factor $\mathrm{X} / \mathrm{Xa}$ were much less and only apparent with $\mathrm{H}_{2} \mathrm{O}_{2}$. Vitamin $\mathrm{E}$ appeared to inhibit the increased expression of factor $\mathrm{X}$. These experiments need to be repeated with a range of doses and exposure-times to further delineate the interaction between peroxides, vitamin $E$ and endothelial cells.

Comparing the results obtained with $25 \mu \mathrm{mol} / \mathrm{l}$ peroxides with the finding of Szatrowski (Szatrowski \& Nathan 1991) that HT29 tumor cells generate $0.1-0.5 \mathrm{nmol} / 10^{4} / \mathrm{h}$ peroxides, we could deduct from this that in our experimental system (in which $100 \mu \mathrm{l}$ of a stock solution of $25 \mu \mathrm{mol} / \mathrm{l}$ peroxides was added to endothelial cells cultured in a 96 well culture plate) approximately $10^{5}$ tumor cells should be capable to induce a similar effect. This amount of tumor cells is comparable to a tumor spheroid of \pm 28 days in culture (Lichtenbeld \& Blijham 1992). Thus, our results obtained with peroxides indicated that it could indeed be possible that small tumor nodules generate sufficient peroxides to induce a morphological and procoagulant response in endothelial cells.

Vesicle formation and procoagulant activity of endothelial cells were first observed in cocultures of tumor spheroids with sprouting endothelial cells in a collagen matrix (see Chapter 4, Lichtenbeld et al.1993). It would be interesting to investigate the effect of peroxide treatment on these sprouting endothelial cells and to find out whether vitamin $E$ could inhibit these tumor-induced effects. Experiments to this extent are in progress.

Taken together the results obtained with peroxides and the previously found results with tumor cells, they support the idea that lipid peroxidation of the endothelial cell membrane could indeed play a role in tumor induced endothelial cell changes and tumor angiogenesis. It has to be mentioned that the tumor cell line (HT29) used in our work is one of the least active cell lines in producing peroxides (Szatrowski \& Nathan 1991). Further evidence for our hypothesis can be obtained by investigating whether a relationship exists between the amount of peroxides generated by tumors and their angiogenic potential and metastatic behavior. 


\section{References.}

Blood C, Zetter B. Tumor interactions with the vasculature: angiogenesis and tumor metastasis. Biochem. Biophys. Acta 1032, 89-118, 1990.

Burgess WH, Maciag T. The heparin binding (fibroblast) growth factor family of proteins. Ann. Rov, Biochem. 58, 575-606, 1989.

Dargel R. Lipid peroxidation - a cornmon pathogenic mochunism? Exp. Toxic Patholl. 44, 169-181, 1992.

Folkman J, Watson $\mathrm{K}$, Ingber $\mathrm{D}$, Hanahan $\mathrm{D}$. Induction of angiogenesis during the transition from hyperplasia to neoplasia. Nature $339,58,1989$.

Folkman J. What is the evidence that tumors are angiogenesis dependent? J. Natl. Cascer Inst, 82(1), 4, 1990.

Folkman J. Tumorangiogenesis. In: Cancer Medicine, 3rd edition. Chapter 11. J. Holland, E. Frei, R. Bast, D. Kufe, D. Morton and R. Weichselbaum, eds. Lea and Febiger Publishers, 1991.

Goldfarb M. The fibroblast growth factor family. Cell Growih and Differentiation, I, 439-445, 1990.

Halliwel B, Gutteridge JMC, Cross CE. Free radicals, antioxidants and human disease: where are we now? J. Lab. Clin. Med. 119, 598-620, 1992

Harris M, Schiller H, Reilly P, Donowitz M, Grisham M, Bulkley G. Free radicals and other reactive oxygen metabolites in inflammatory bowel disease: cause, consequence or epiphenomenon? Pharm. Ther. $53,375-408,1992$.

Hiraishi H, Terano A, Razandi M, Sugimoto T, Harada T, Ivey K. Role of cellular superoxide dismutase against reactive oxygen metabolite injury in cultured bovine artic endothelial cells. J. Biol. Chem. 267, 21 , 14812-14817, 1992.

Jaffe EA, Nachman RL, Becker CG, Minick CR. Culture of human endothelial cells derived from umbilicial veins. J. Clin. Invest. 52, 2745, 1973.

Kandell J, Bossy-Wetzel E, Radvanyi F, Klagsbrun M, Folkman J, Hanahan D. Neovascularization is associated with the switch to the export of bFGF in the multistep development of fibrosarcoma. Cell 66 , 1095-1104, 1991.

Klagsbrun M, D'Amore PA. Regulators of angiogenesis. Ann. Rev. Physiol. 53, 217-239, 1991.

Leibovich S, Polverini P, Shephard H, Wisemen D, Shively V, Nuseir N. Macrophage-induced angiogenesis is mediated by tumour necrosis factor alpha. Nature 329, 630-632, 630-632, 1987 .

Leung D, Cachianes G, Kuang WJ, Goeddel DV, Ferrara N. Vascular endothelial growth factoris a secreted angiogenic mitogen. Science 246, 1306-1309, 1989.

Lichtenbeld HC, Blijham GH. Tumor cell spheroids induce a mitogenic response in endothelial cells. In: Angiogenesis: Key principles, Science, Technology, Medicine. R. Steiner, P.B. Weisz, and R. Langer, Eds. Birkhäuser Verlag Basel, 261-265, 1992.

Lichtenbeld HC, Muller AD, Van Dam-Mieras MCE, Blijham GH. Tumor spheroid induced vesicle formation on endothelial cells is associated with procoagulant properties. Eur. J. Cell Biol. Suppl.37, 
Vol.60, 69, 1993.

Maciag T, Cerundolo J, Ilsley S, Kelley PR, Foriand R. An endothelial cell growth factor from bovine hypothalamus: Identification and partial characterization. Proc. Natl. Acad. Sci. USA, 76, 5674-5678, 1979.

Patel JM, Sekharam M, Block ER. Vitamin E distribution and modulation of the physical state and function of pulmonary endothelial cell membranes. Exp. Lung Res. 17, 707-723, 1991.

Rastinejad F, Polverini PJ, Bouck NP. Regulation of the activity of a new inhibitor of angiogenesis by a cancer suppressor gene. Cell 56, 345, 1989.

Roberts A, Spom M, Assionn R, Smith J, Rocbe N, Wakefield L, Heine U, Liotta L, Falanga V, Kehrl J, Fauci A. Transforming growth factor type beta: rapid induction of fibrosis and angiogenesis in vivo and stimulation of collagen formation in vitro. Proc. Natl. Acad. Sci. USA 83, 4167-4171, 1986

Schroit AJ, Zwaal RFA. Transbilayer movement of phospholipids in red cell and platelet membranes. Biochem. Biophys. Acta 107, 313-324, 199 I.

Szatrowski T, Nathan C. Production of large amounts of hydrogen peroxides by human tumor cells. Cancer Res. 51, 794-798, 1991.

Van Dam-Mieras MCE, Muller AD, Van Hinsbergh VWM, Mullers WJHA. Bomans PHH. Bruggeman CA. The procoagulant response of cytomegalovirus infected endothelial cells. Thromb. Haemostas. 68(3) 364-370, 1992.

Voest E, Vun Fanssen E, Van Asbeck B, Neijt J, Marx J. Increased hydrogen peroxide concentration in human tumor cells due to a nitroxide free radical. Biochem. Biophys. Acta 1136, 113-118, 1992. 



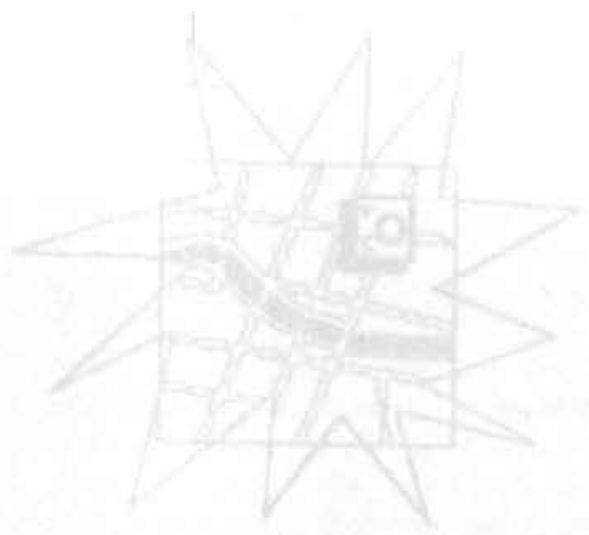




\title{
Chapter 6.
}

\section{Mast cells modify tumor induced procoagulant properties of endothelial cells.}

Based on: Muller A.D., Lichtenbeld H.H.C., Vossen R.C.R.M., Blijham G.H., Van DamMieras M.C.E. Mast cells induce a procoagulant response on endothelial cells. Thromb. Res. 1993 (accepted)

\begin{abstract}
.
Mast cells have fuscinated many investigators since their initial definition by Elhrlich. They seem to play multiple roles in pathologic processes such as hypersensitivity, inhammation. cardiovascular disense and cancer. In vivo, mast cells are found in close proximity to small blood vessels and their number increases shortly before the onset of neovessel formation from existing host vessels. Therefore, we investigated the interaction between mast cells and endothelial cells, with or without the presence of tumor ce!ls in en in vitro model for angiogenesis.

Mast cells elecited a dose-related stimulating effect on the proliferation of endothelial cells. Mast cell lysate strongly inhibited thrombin activity, companable to the effect of the known antithrombotic combination of heparin plus anti-thrombin III. Mast cell lysate accelerated the formation of fibrin on endothelial cell monolayers and upon addition of mast cells to co-cultures of endothelial cell aggregates and HT29 tumor spheroids, a significant increase in the expression of factor $\mathrm{Xa}$ was found without affecting the factor $\mathrm{X}$ expression. When mast cells were involved it was no longer possible to inhibit the expression of either factor $X$ or $X:$ with an anti- $X$ antibody.

Our experiments indicated that mast cells might be involved at several stages in the angiogenic process by interfering with the coagulation properties of endothelial cells and possibly have regulatory properties as well.
\end{abstract}

Introduction.

Mast cells have fascinated many investigators since their initial definition by Ehrlich (Ehrlich 1879). They seem to play multiple roles in pathologic processes such as hypersensitivity, inflammation, cardiovascular disease and cancer (Dvorak 1991). In vivo, mast cells are found in close proximity to small blood vessels and their number increases shortly before the onset of neovessel formation from existing host vessels (Meininger \& Zetter 1992). Mast cells contain among others histamin, heparin, proteoglycans, prostaglandin D2, leucotriens, platelet activating factor and tumor necrosis factor $\alpha$. Part of their overal function is to locally increase vascular permeability (Dvorak et al.1985, Dvorak 1991).

The role of mast cells in tumor growth has since long been recognized (Andral \& Gavarret 1842, Trousseau 1885), but its significance is controversial. Experimental results. have been interpreted to reflect mast cell cytotoxicity towards the tumor cells (Burtin et al.1985) as well as to support tumor growth (Roche 1985,1986, Dabbous et al.1991). It 
has been found that mast cells accumulate around tumors shortly before the onset of angiogenesis (Kessler et al.1976, Roche 1985, Folkman et al. 1988) and could play a role in tumor growth and particularly in tumor angiogenesis (Folkman 1986, Poole \& Zetter 1983, Dabbous et al.1986, Starkey et al.1988). It is not clear whether mast cells elicit their effects directly on the endothelial cell or indirectly by degrading the matrix in order to facilitate capillary sprouting (Meininger \& Zetter 1992). Although tumor angiogenesis seems not to be absolutely dependent on the presence of mast cells, its initiation is strongly delayed in their absence (Starkey et al.1988, Meininger \& Zetter 1992).

To gain further insight in the role of mast cells in tumor angiogenesis, we investigated the interaction between mast cells and endothelial cells, with or without the presence of tumor cells in an in vitro model for angiogenesis. We specifically wanted to know whether mast cells could be involved in the formation of fibrin that is present in growing tumors and may be beneficial for tumor growth (Dvorak 1986). Our results showed that mast cells could elecit a direct effect on endothelial cells by increasing the procoagulant properties of endothelial cells. Cocultivation of endothelial cells, tumor cells and mast cells modified this effect.

\section{Materials and Methods.}

Endothelial cells.

Bovine Capillary Endothelial cells (BCE), kindly provided by Dr.M.Furie, University of New York, Stony Brook, U.S.A. were cultured on gelatin coated culture flasks (Costar) in Minimal Essential Medium $\alpha$-modification (GIBCO) with 15\% Donor Calf Serum (DCS) (Flow Laboratories).

\section{Tumor cells.}

Cells from the colorectal tumor cell line HT29 (Fogh et al.1977) were cultured in Dulbecco's Modified Essential Medium (GIBCO) supplemented with 10\% Bovine Calf Serum (BCS) (Hyclone, Greiner).

\section{Mast cells.}

Rat peritoneal mast cells were isolated according to a modified method of Schwartz (Schwartz et al.1979), which provided a method to obtain a $97 \%$ pure mast cell population.

Briefly, healthy Wistar or Norway Brown rats over three months old, were injected i.p. with sterile phosphate buffered saline (PBS) with $0.1 \%$ gelatin, i.e. lavage-buffer, with a infusion syringe (Abbocath-T 14Gx51 mm, Abbott, Ireland). After gentle massaging, the lavage-buffer was collected through the syringe in a sterile tube and centrifuged 5 minutes at $195 \mathrm{~g}$. The following procedure was performed in a laminar-flow hood using sterile materials and solutions. Cells were washed twice in lavage-buffer with heparin $(10 \mathrm{IU} / \mathrm{ml}$ final concentration) and resuspended in $2 \mathrm{ml}$ lavage-buffer with heparin. The suspension was layered on a density gradient of $2.5 \mathrm{ml} \mathrm{22.5 \%} \mathrm{Metrizamide} \mathrm{(Centrifugation} \mathrm{Grade,}$ Pharmachemie, Nyegaard \& Co, Oslo, Norway) and centrifuged 15 minutes at $470 \mathrm{~g}$. The upper layer was removed and cells were washed in lavage-buffer with heparin. The 
pellet was resuspended in $1 \mathrm{ml}$ buffer with heparin and layered on a two-step velocity gradient ( $3 \%$ metrizamide on $9 \%$ metrizamide) to eliminate the remaining erythrocytes and centrifuged 10 minutes at $50 \mathrm{~g}$. Cells were washed twice in lavage-buffer wirhout heparin and finally the cell pellet was resuspended in serum-free $\alpha$-MEM.

Mast cell lysate.

Isolated mast cells were suspended in $\alpha$-MEM without any supplements. The cells were sonicated (50 Mhz in an ultrasone bath) and the lysate was stored at $4^{\circ} \mathrm{C}$. In the description of the experiments "mast-cells" refer to the lysate obtained from the amount of mast cells indicated.

\section{Proliferation assay.}

This assay was a modification of the previously described proliferation assay for endothelial cells (Lichtenbeld \& Blijham 1992) using the thymidin analogue bromodeoxyuridin (BrdU). To prevent direct mast cell-endothelial cell contact, mast cells in different concentrations were introduced to confluent endothelial monolayers in separate compartments using $0.45 \mu \mathrm{m}$ inserts (Falcon, Becton \& Dickinson Co. NY). BCE monolayers were cocultivated with the mast cells for 24 hours. The percentage BrdU positive cells was scored (labeling index, LI) as a measure for cell proliferation.

\section{Thrombin inhibition assay.}

The thrombin inhibitory activity of mast cells was determined in a two-stage thrombin assay (Van Dam-Mieras et al. 1984). Coagulation times were measured by adding $0.1 \mathrm{ml}$ of a thrombin-solution (3 IU/ml thrombin, Roche, Basel in Michaelis buffer $\mathrm{pH} 7.4$ ) to $0.1 \mathrm{ml}$ of a fibrinogen solution $(2.8 \mathrm{~g} / \mathrm{l}$, Behring, in Michaelisbuffer $\mathrm{pH} 7.4)$ after incubation with Michaelis buffer ( $\mathrm{pH} \mathrm{7.4)}$ or an inhibitor-preparation for different time intervals. The heparin inhibitor Polybrene was used (final concentration $1 \mu \mathrm{g} / \mathrm{ml}$ which is equivalent to the concentration that blocks $1 \mathrm{IU} / \mathrm{ml}$ heparin in normal human plasma). All experiments were carried out in quadruplo at $37^{\circ} \mathrm{C}$. In the thrombin inhibition assay the concentration of lysate used per experiment was equivalent to the amount of mast cells (respectively 3000 or 300 ) from which the lysate was obtained.

The following inhibitor-preparations were used:

1: anti-thrombin III (0.005 IU/ml; Diagnostica Stago)

2: anti-thrombin III + heparin $(0.1 \mathrm{IU} / \mathrm{ml}$; Sigma, St. Louis)

2a: anti-thrombin III + heparin + polybrene $(1 \mu \mathrm{g} / \mathrm{ml})$

3: anti-thrombin III + mast cell lysate

3a: anti-thrombin III + mast cell lysate + polybrene $(1 \mu \mathrm{g} / \mathrm{ml})$

4: heparin

4a: heparin + polybrene $(1 \mu \mathrm{g} / \mathrm{ml})$

5: mast cell lysate

5a: mast cell lysate + polybreen $(1 \mu \mathrm{g} / \mathrm{ml})$

6: mast cell lysate + heparin

6a: mast cell lysate + heparin + polybrene $(1 \mu \mathrm{g} / \mathrm{ml})$ 
Clotting time assay on endothelial cells.

Clotting times were measured on endothelial cells treated with different concentrations of mast cell lysate for respectively 24 and 48 hours. This assay was based on a previously described method (Van Dam-Mieras et al.1992). Briefly, BCE cells were cultured on gelatin coated 96-well strips (NUNC). Per well $\pm 1 \times 10^{4}$ endothelial cells were present at confluency. Mast cell lysate was added to the endothelial cell cultures at the following "mast-cell" : endothelial-cell ratios: $0.1: 1,1: 1$ or 10:1. After 24 or 48 hours, supernatants were removed, cells washed once and incubated at $37^{\circ} \mathrm{C}$ with $180 \mu \mathrm{l} /$ well pooled normal human plasma/Michaelis buffer ( $\mathrm{pH} 7.4)(1: 1, \mathrm{v} / \mathrm{v})$. After 3-5 minutes 90 $\mu \mathrm{l} /$ well $\mathrm{CaCl}_{2}(0.033 \mathrm{M})$ was added and the clotting time measured $(n=8)$.

Cocultures of endothelial cells, tumor cells and mast cells in Vitrogen.

This assay was a modification of the method of Montesano (Montesano 1992).

Endothelial cells (BCE) were cultured until confluency, trypsinized and transferred to a $35 \mathrm{~mm}$ dish coated with $0.5 \%$ agarose to prevent adherence and promote the formation of endothelial aggregates. After 24 hours the aggregates were separated from single cells by gravitational force, followed by embedding in a collagen type I gel (Vitrogen, Collagen Corp, Palo Alto) in a 96 wells plate either as solitary cultures or with respectively HT29 tumor cells ( 300 cells/well), mast cells (300 cells per well), or both cell types and cultured for 48 hours.

Determination of $\mathrm{X}-\mathrm{Xa}$ expression in cultures in Vitrogen.

After 48 hours, the culture medium was removed, collagen gels were washed once and factor X and Xa expression measured as follows (Van Dam-Mieras et al. 1992):

Factor $X$

Per well $25 \mu \mathrm{l}$ RVV (Russell's Viper Venom; 1 vial containing $1 \mathrm{mg}$ factor $\mathrm{X}$ activating protein in $0.1 \mathrm{mmol} / \mathrm{l} \mathrm{NaCl}$, dissolved in $15 \mathrm{ml}$ destilled water), $25 \mu \mathrm{l}$ trisbuffer $(0.05$ $\mathrm{mol} / \mathrm{l}, 20 \mathrm{mg} / \mathrm{l}$ polybrene, $\mathrm{pH} 7.8)$ and $25 \mu \mathrm{l} \mathrm{CaCl}(0.01 \mathrm{~mol} / \mathrm{l})$ were added and the mixture was incubated for 15 minutes at $37^{\circ} \mathrm{C}$. Then $50 \mu \mathrm{l}$ of the chromogenic substrate \$2337 (1 vial containing $30 \mu \mathrm{mol} / 1$ dissolved in $20 \mathrm{ml}$ destilled water) was added to the well. After 60 minutes incubation at $37^{\circ} \mathrm{C}$ citric acid GR (4\%) was added and extinction measured at $405 \mathrm{~nm}$.

Factor $\mathrm{Xa}$

Per well $50 \mu \mathrm{l}$ tris buffer $(0.05 \mathrm{~mol} / \mathrm{l}, 20 \mathrm{mg} / \mathrm{l}$ polybrene, $\mathrm{pH} 7.8)$ and $25 \mu \mathrm{l} \mathrm{CaCl}_{2}$ $(0.01 \mathrm{~mol} / \mathrm{l})$ were added and the mixture was incubated for 15 minutes at $37^{\circ} \mathrm{C}$. Then 50 $\mu \mathrm{l}$ of the chromogenic substrate $\mathrm{S} 2337$ (1 vial containing $30 \mu \mathrm{mol} / \mathrm{l}$ dissolved in $20 \mathrm{ml}$ destilled water) was added to the well. After 60 minutes incubation at $37^{\circ} \mathrm{C} 25 \mu$ l citric acid GR (4\%) was added and the extinction was measured at $405 \mathrm{~nm}$.

\section{Factor $X / X a$ expression in mast cell lysate.}

In order to exclude that the detected factor $\mathrm{X} / \mathrm{Xa}$ expression in our cultures was due to an artefact from the mast cells, the mast cell lysate was tested for the presence of factor $\mathrm{X} / \mathrm{Xa}$ activity. Mast cell lysates were prepared as described previously.

Factor X (1 mg) (Diagnostica Stago, Paris, France) was dissolved in $1 \mathrm{ml}$ destilled water and arbitrarily defined as $1 \mathrm{IU} / \mathrm{ml}$. Mast cells $\left(3 \times 10^{3} / \mathrm{ml}\right)$ were incubated at $37{ }^{\circ} \mathrm{C}$ with or 
without factor $X(0.04 \mathrm{IU} / \mathrm{ml})$ for respectively $30,60,90$ and 120 minutes.

Subsequently, factor $\mathrm{X}$ and $\mathrm{Xa}$ expression were determined as described above.

\section{Slatistical Analyses.}

Statistical analyses are performed using the Wilcoxon Mann Whitney test.

\section{Results.}

Mast cell lysate had a dose-related stimulating effect on the proliferation of endothelial cells. In a "mast cell" : endothelial cell ratio of $0.1: 1$ or $1: 1$, no effect was found on endothelial cell proliferation. However, a 10:1 ratio increased the proliferation rate of endothelial cells about 1.5 -fold. This is in agreement with previous findings of Marks (Marks et al. 1986).

In our search for a possible role for mast cells in tumor induced fibrin formation and angiogenesis, we first investigated the effect of mast cell lysates on thrombin activity in the fluid phase. Results are shown in figure 1.

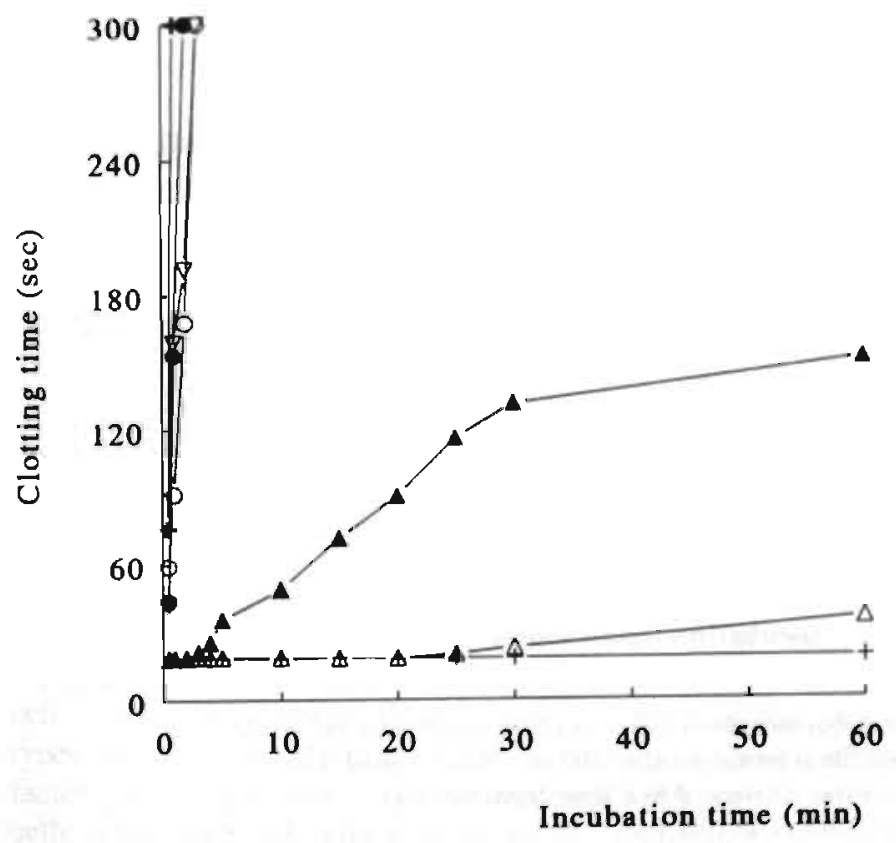

Figure 1. Inhibition of thrombin activity by mast cell lysate. Thrombin activity was measured in Michaelis buffer $(+)$, buffer with antithrombin III $(\Delta)$, buffer with Heparin ( $\Delta)$, buffer with heparin in combination with ATIII $(O)$, in mast cell lysate $(O)$, in mast cell lysate with the addition of ATIII $(+)$ or heparin $(\nabla)$.

Buffer alone or antithrombin III did not inhibit fibrin formation. Heparin inhibited fibrin formation in a time dependent way. Heparin in combination with ATIII, known for the 
anticoagulant properties, totally prevented fibrin formation. Mast cell lysate was capable to either totally prevent (at high lysate concentration) or inhibit (at lower lysate concentration) fibrin formation as well. Addition of ATIII or heparin increased this effect only at low mastcell lysate concentrations. The addition of polybrene blocked the activity of heparin + anti-thrombin III and only slightly inhibited the anti-thrombin effect of mast cell lysate.

We subsequently studied the effect of the mast cell lysate on endothelial cell procoagulant activity. Mast cell lysate accelerated fibrin formation on endothelial cells. This effect was time and dose dependent and was strongest at a mast-cell:endothelial-cell $0.1: 1$ ratio, as shown in figure 2.

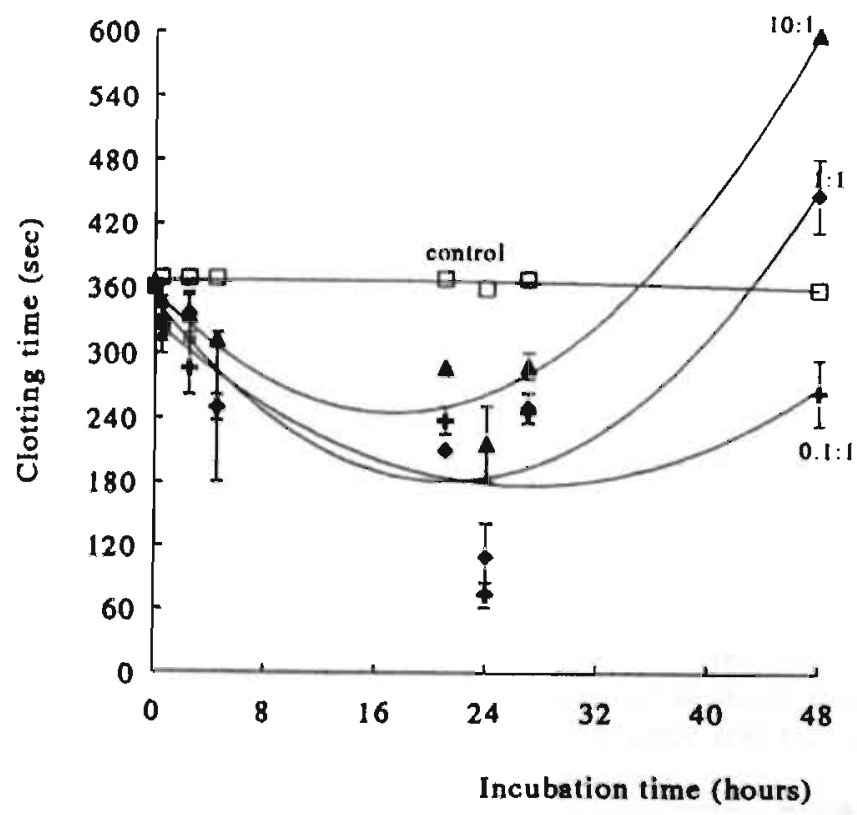

Figure 2. Fibrin formation on endothelial monolayers after incubation with mast cell lysate.

Non-treated endothelial cells showed fibrin formation after $360 \mathrm{sec}$. When treated with mast cell lysate, this fibrin formation was accelerated in a dose dependent way ("mast-cell" : endothelial-cell ratio: $0.1: 1 \quad 1: 1 \quad$ 10:1).

We previously described (Lichtenbeld et al.1993) a tumor-induced procoagulant response as measured by an enhanced factor $\mathrm{X} / \mathrm{Xa}$ expression on endothelial cells. We therefore subsequently investigated the influence of mast cell lysate on factor $\mathrm{X} / \mathrm{Xa}$ expression on endothelial cells. The results obtained are shown in figure 3. 


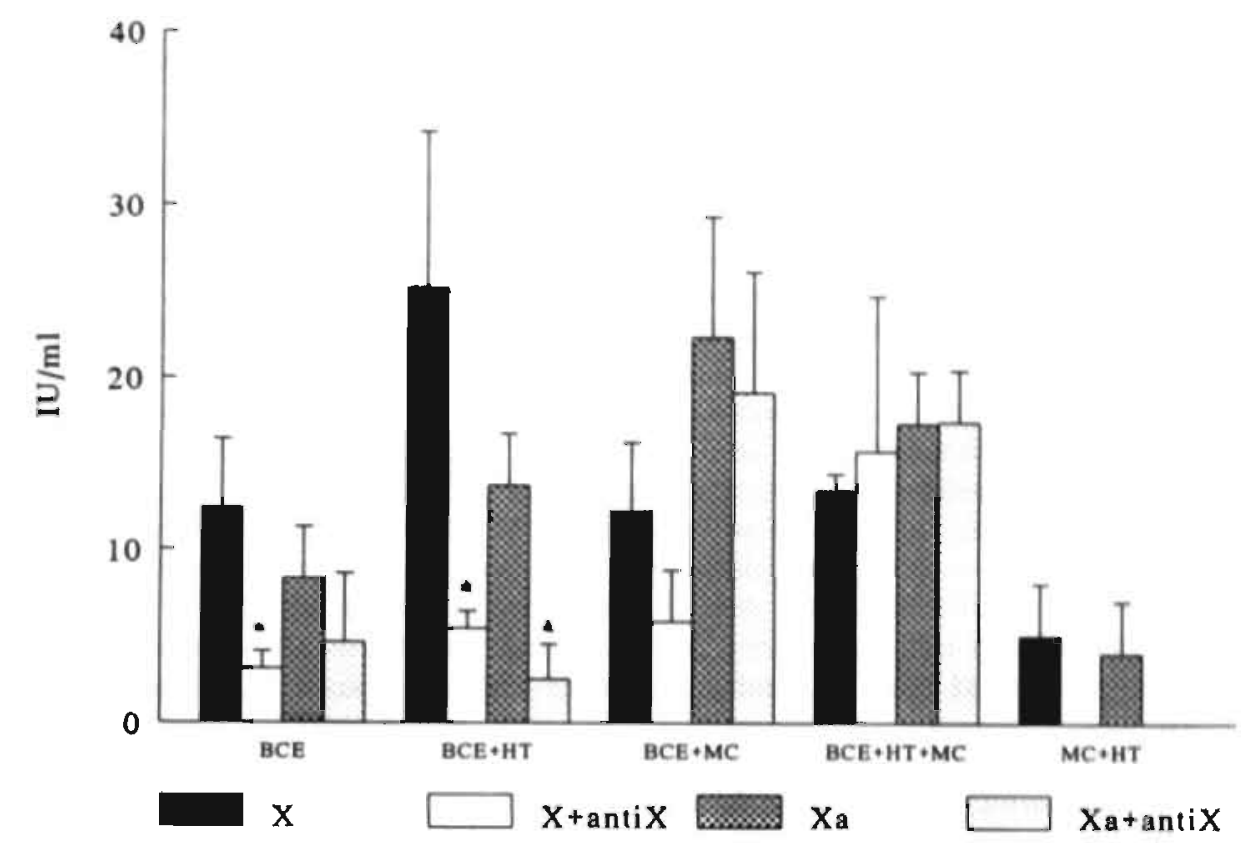

Figure 3. Factor $X$ and $X \mathrm{a}$ expression in control cultures, endothelial cell aggregates (BCE), Aggregates cocultured with tumor cells $(B C E+H T)$ show a significant $(P<0.05)$ increase in factor $\mathrm{X}$ and $\mathrm{Xa}$ expression. Aggregates cocultured with mast cells $(\mathrm{BCE}+\mathrm{MC})$ and aggregates cocultured with tumor cells and mast cells $(B C E+H T+M C)$ show a preferentially increased expression in factor $\mathbf{X} \mathbf{a}$.

After addition of anti-X antibody both factor $X$ and $X a$ are significantly $(P<0.05)$ inhibited in the endothelial aggregate cultures (BCE) and in the endothelial aggregate with tumor cultures (BCE +HT). However, this inhibition is not found in the cultures involving mast cells.

Mast cells appeared to enhance the expression of factor Xa significantly without affecting the factor X expression. The opposite was found for tumor cells, which induced a larger increase in factor $\mathrm{X}$ expression than in factor $\mathrm{Xa}$ expression. The combination of the two cell types yielded predominantly a factor Xa response; no synergism between the cell types was observed. In case of a tumor induced response of endothelial cells the increased factor $\mathrm{X} / \mathrm{Xa}$ expression could be inhibited with anti-X antibody. In contrast, when mast cells were involved, either alone or in combination with tumor cells, anti-X antibody could no longer inhibit the expression of either factor $\mathrm{X}$ or $\mathrm{Xa}$.

Finally we also investigated if the mast cell lysate had a direct effect on the conversion of factor $\mathrm{X}$ into $\mathrm{Xa}$ in the fluid phase or that a factor $\mathrm{X} / \mathrm{Xa}$-like activity is measured; figure 4 shows this is not true. 


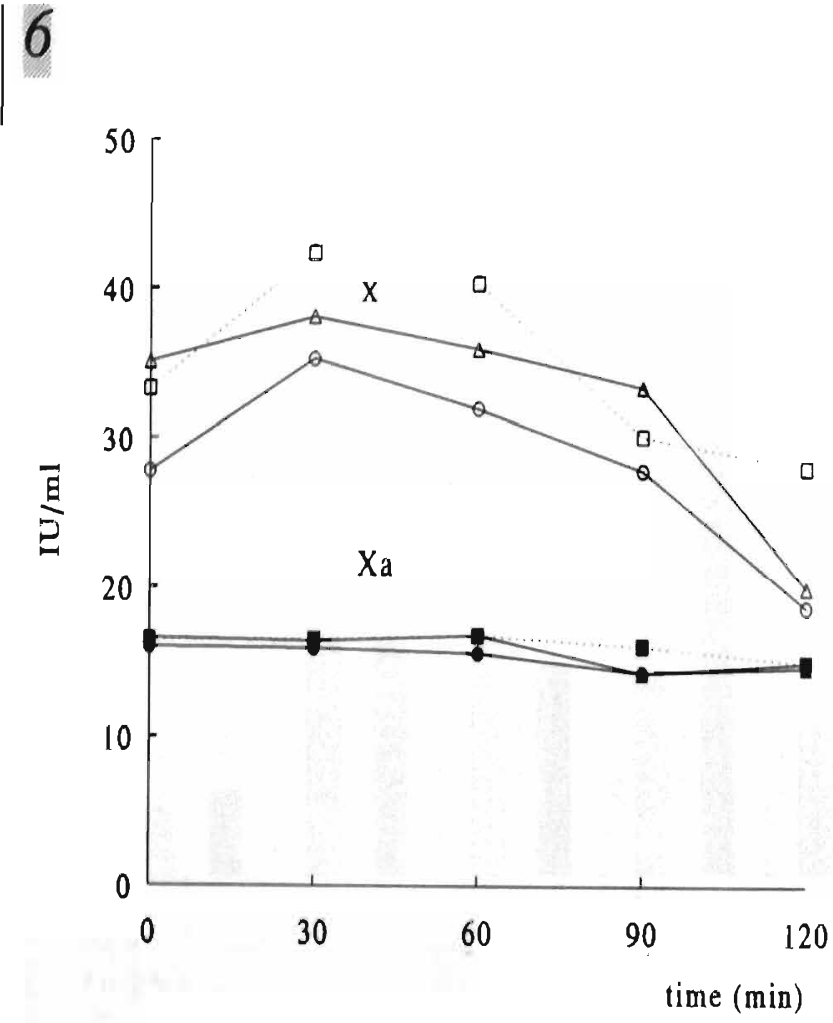

Figure 4. Mast cell lysates were tested for their capability to convert factor $\mathrm{X}$ into factor $\mathrm{Xa}$. As control values pure factor $X(\square)$ and $X_{a}(\square)$ were determined. No increase in factor $X(0)$ or $\mathrm{X}(0)$ activity was found in masi cell lysate and neither when a defined amount of pure factor $X$ was added to the mast cell lysate, factor $X(\Delta)$ or factor $X a(\Delta)$ expression was not increased.

\section{Discussion.}

Coagulation leading to fibrin formation could be benificial for the tumor as it provides a provisional matrix for the tumor to grow and to develop a vascular network in (Dvorak 1986). We previously described that tumor cells could induce a procoagulant response in endothelial cells and hypothesized that this might contribute to the formation of fibrin. In vivo shortly before the onset of tumor induced angiogenesis accumulation of mast cells is seen around the tumor nodule (Meininger and Zetter 1992). In search for a possible influence of mast cells during the formation of a provisional fibrin stroma, we investigated whether mast cells had an influence on the endothelial cell procoagulant response. The results showed that indeed mast cells contribute to the procoagulant status of endothelial cells and thereby might play a role in fibrin formation (Meininger \& Zetter 1992, Dvorak 1988).

Mast cell lysate, if added to endothelial cell monolayers accelerated the fibrin formation (see figure 2). Intact mast cells, if added to sprouting endothelial cells in vitrogen led to an enhanced factor Xa expression (see figure 3). This induction of a procoagulant phenotype sharply contrasted with the effect of mast cell lysate in the fluid phase, where it appeared to be a very potent inhibitor of thrombin (see figure 1). This latter effect was 
thought 10 be due to the heparin-like molecules that occur abundantly in mast cells (Dvorak et al.1991, Meininger \& Zetter 1992). However, the heparin blocking agent polybrene did not block this effect which could mean that the thrombin inhibiting effect from mast cell lysate is either not caused by heparin-like components from the mast cells or that polybrene is not capable to inhibit mast cell derived heparin-like components. Other preformed mediators that are released by mast cells include histamin, proteoglycans, prostaglandin D2, leukotreines, platelet activating factor and tumor necrosis factor $\alpha$ (TNF- $\alpha$ ) (Galli et al.1988, Dvorak et al.1991). Presently we can not conclude if any of these substances are involved in inducing the procoagulant effect.

Mast cells and tumor cells apparently induced procoagulant activity on endothelial cells in different ways. Both tumor cells and mast cell led to the enhanced expression of factor $\mathrm{X} / \mathrm{Xa}$, but in case of mast cells, $\mathrm{Xa}$ was preferentially expressed at the expense of factor $X$, and moreover its expression could no longer be blocked by anti- $X$ antibody. Since the total $\mathrm{X} / \mathrm{Xa}$ activity was not enhanced by combining the two cell types, we could hypothesize that the association of factor $\mathrm{X}$ with the endothelial cell membrane after incubation with the tumor and mast cells, was similar but mast cells induced activation and probably also a conformational change of factor $\mathrm{X}$. To our knowledge, such changes have not been described before.

Mast cells are attracted into tumors by tumor-derived chemotactic fators (Poole \& Zetter 1983, Roche 1986). Their role in tumor induced angiogenesis remains obscure but our experiments indicated that mast cells might be involved at several stages in the angiogenic process. First, by increasing endothelial cell permeability and exerting a direct anticoagulant effect in the fluid phase, mast cells might stimulate plasma protein extravasation through the endothelial layer. Several of these plasma proteins are involved in the coagulation cascade, so this process can contribute to fibrin formation. The intruiging observation that mast cell lysate promoted cell associated procoagulant activity could easily be reconciled with mast cell induced extravascular fibrin formation; increased extravasation of plasma proteins combined with a cell associated procoagulant effect will result in perivascular fibrin deposits. Second, it has been described that mast cell derived heparin increased endothelial cell motility (Azizkhan et al.1980), and that mast cell derived histamin stimulated endothelial cell proliferation (Marks et al.1986).

This stimulation of endothelial cell motility and proliferation, confirmed by our results, could favor the formation of capillaries in the perivascular structure.

Finally, also the presence in mast cells of proteolytic compounds that can degrade the extracellular matrix, could facilitate neovessel formation and tumor expansion.

Such model in which mast cell products contribute to plasma extravasation, fibrin formation, matrix degradation, cell motility and proliferation would very well be in line with the observations that mast cells are found around the tumor nodule shortly before the onset of vessel formation and that the absence of mast cells strongly delays the angiogenic process (Starkey et al.1988, Meininger 1992). 
Acknowledgements.

The authors wish to thank Drs P. Lemmens and Ch. van Haaster of the Cardiovascular Research Institute Maastricht (CARIM), the Netherlands, for teaching the isolationprocedure for rat peritoneal mast cells and P. Kelderman, J. Wiertz and F. Weekers of the Central Laboratory Animals lacilities for their technical assistance.

\section{References.}

Andral et Gavarret. Recherches sur le modifications de proportion de quelques principe du sang: fibrine, globules, matériaux solides du sérum et eau dans les maladies. Paris, Fortin Masson et $C^{*}$ libraires. 225239,1842 .

Azizkhan RG, Azizkhan CJ. Zetter BR, Folkman J. Mast cell heparin stimulates migration of capillary undothelial cells in vitro. J. Exp. Med. 152, 931-944, 1980.

Burtin C, Ponven C. Fray A, Scheinmann P, Lespinats G. Loridon B, Canu P, Paupe J. Inverse correlation between tumor incidence and tissue histamine levels in $W / W v, W v / t$ and $+1+$ mice. J. Natl. Cancer Inst. $74,671-674,1985$.

Dabbous M, Walker G, Haney L, Carter N, Nicholson G, Woolley D. Mast cells and matrix degradation at sites of tumour invasion in rat mammary adenocarcinoma. Br. J. Cancer 54, 459-465, 1986.

Dabbous MKh, Haney L, Nicolson GL, Eckley D, Woolley DE. Mast cell modulation of tumour cell proliferation in rat mammary adenocarcinoma 13762NF. Br. J. Cancer 63, 873-878, 1991.

Dvorak AM. Blood Cell Biochemistry. Vol.4. Basophil und Mast cell degranulation and recovery. Plenum Press New York, 1991.

Dvorak HF, Senger DR, Harvey VS, McDonagh J. Regulation of extravascular coagulation by microvascular permeability. Science 227, 1059-1061, 1985.

Dvorak HF. Tumors: wounds that do not heal. New Eng. J. Med. 315, 1650-1659, 1986.

Dvorak HF. Tumor stroma. In: Diagnostic Immunopathology. RB Colvin, AK Bhan and RT McCluskey editors, Raven Press New York. Chapter 15, p.401-420. 1988.

Ehrlich P. Beitrage zur Kenntniss der Granulierten Bindegewebszellen und der Eosinophilen Leukocythen. Verhandlungen dér Berliner Physiologischen Gesellschaft Nr.5, 166-169, 1879.

Fogh J, Fogh JM, Orleo T. One hundred and twenty seven cultured human tumor cell lines producing tumors in mice. J. Natl. Cancer Inst. 59, 221-226, 1977.

Folkman I. How is blood vessel growth regulated in normal and neoplastic tissue? G.H.A. Clowes memorial award lecture, Cancer Res. 46, 467, 1986.

Folkman J. Taylor S. Spillberg C. The role of heparin in angiogenesis. Ciba-Geigy Foundation 100, 132149, 1988 .

Galli SJ, Lichtenstein LM. In: Allergy: prnciples and practice. Middleton E, Reed CE. Ellis EF, Aúkinson NF. Yuninger JW eds. CV Mosby, St. Louis, 106-134, 1988. 
Kessler DA, Langer RS, Pless NA. Folkman J. Mast cells and tumor angiogenesis. Int. J. Cancer 18, 703. 709, 1976.

Lichtenbeld HC, Blijhan GH. Tumor cell spheroids induce a mitogenic response in endothelial cells. Angiogenesis: Key principles, Science, Technology, Medicine. R. Steiner, PB Weisz and R, Langer, Eds. Birkhiuser Verlag Busel, 261-265, 1992.

Lichtenbeld HC, Muller AD, Van Dam-Mieras MCE, Blijhm GH. Tumor cell spheroids elecit procoagulant response in endothelial cells in vitro. Eur. J. Cell Biol. Suppl.37, Vol.60, 69, 1993.

Marks RM, Roche WR. Czerniecki M, Penny R, Nelson DS. Mast cell granules cause proliferation of human microvascular endothelial cells. Lab. Invest. 55, 289-294, 1986.

Meininger CJ, Zetter BR. Mast cells and angiogenesis. Semin. Cancer Biol. 3(2), 73-79, 1992.

Montesano R. Regulation of angiogenesis in vitro. Eur. J. Clin. Invest. 22, 504-513, 1992

Poole TJ, Zetter BR. Stimulation of rat peritoneal mast cell migration by tumor-derived peptides. Cancer Res. 43 (12 PI.1), 5857.5861, 1983.

Roche WR. Mast cells and tumors; the specific enhancement of tumor proliferation in vitro. Am. J. Pathol. 119 (1), 57-64, 1985.

Roche WR. The nature and significance of tumour-associated mast cells. J. Pathol. 48, 175-182, 1986.

Schwartz L, Austin K, Wasserman S. Immunologic release of B-hexosamidase and B-gluceronidase from purified rat serosal mast cells. J. Immunol. 123, 1445-1450, 1979.

Starkey JR, Crowle PK, Taubenberger S. Mast-cell deficient $w / w^{v}$ mice exhibit a decreased rate of tumor angiogenesis. Int. J. Cancer 42, 48-52, 1988.

Trousseau A. Phlegmatia alba dolens. Clinique médicale de L'Hotel-dieu de Paris. Librairie J.B.Baillière et fils. septième édition, 695-705, 1885.

Van Dam-Mieras MCE, Muller AD, Hemker HC. Blood coagulation factors II, V, VII, IX, X and XI determinations by clotting assays. Methods of enzymatic analysis Vol.V, Verlag Chemie GmbH, Weinheim FRG, pp.352-365, 1984.

Van Dam-Mieras MCE, Muller AD, Van Hinshergh VWM, Mullers WJHA, Bomans PHH, Bruggeman CA. The procoagulant response of cytomegalovirus infected endothelial cells. Thromb. Haemostas. 68(3) 364-370, 1992. 


\section{Chapter 7.}

\section{Cisplatin and 5-Fluorouracil inhibit endothelial cell proliferation and interfere with endothelial cell procoagulant activity.}

\section{Introduction.}

It has been postulated that coagulation and fibrin formation could be benificial for the growth and development of tumors since fibrin could provide a provisional matrix in which the endothelial cell can migrate and proliferate to develop a vascular network (Donati et al. 1981, Dvorak 1986, Dvorak et al.1987). Supportive to this, we have found recently that tumors stimulate the proliferation rate and procoagulant response of endothelial cells in vitro (Lichtenbeld \& Blijham 1992, Lichtenbeld et al. 1993).

In cancer, the antineoplastic drugs 5-fluorouracil (SFU) and cisplatin (CDDP) or a combination of the two are widely used (Loehrer et al.1985, O'Connell et al. 1986, Sileni et al.1992, Thyss et al.1986, Etienne et al.1991). CDDP is a representative for the group of agents that bind to DNA whereas 5FU is a pyrimidine antagonist thus inhibiting DNA synthesis (Chabner \& Collins 1990). Although the main goal of chemotherapy is to attack the highly proliferative tumor cell, we were interested to know whether these drugs would interfere with the endothelial cell properties, thus interfering with tumor vascularization and expansion.

We studied, in an in vitro model, the endothelial cell reactivity to chemotherapeutic drugs by measuring the proliferative and pro- and anti-coagulant response of the endothelial cell.

Materials and methods.

Endothelial cells.

Bovine Capillary Endothelial cells (BCE), kindly provided by Dr.M.Furie, University of New York, Stony Brook, U.S.A. were cultured on gelatin coated culture flasks in Minimal Essential Medium $\alpha$-modification (GIBCO) with $15 \%$ Donor Calf Serum (DCS) (Flow Laboratories) (DCSMEM).

\section{Proliferation assay.}

5-FU (Pharmachemie, Haarlem, the Netherlands) and CDDP (Cyanamid, Benelux) were freshly prepared before use. Concentrations used were within clinically relevant ranges (Borenfreund et al.1990, Etienne et al.1991): $20 \mu \mathrm{M}, 100 \mu \mathrm{M}$ and $1 \mathrm{mM}$ for 5FU and 20 $\mu \mathrm{M}$ and $80 \mu \mathrm{M}$ for CDDP, and $20 \mu \mathrm{M}$ for each of the drugs when administered together. The drugs were dissolved in $\alpha$-MEM (GIBCO). The bromodeoxyuridine incorporation 
assay is used to measure endothelial cell proliferation (Lichtenbeld \& Blijham 1992).

The endothelial cells were incubated for 24 hours with the drugs before BrdU was added and the proliferation measured.

\section{Recovery assay.}

After treatment of the endothelial cells for 24 hours with chemotherapeutic drugs, the medium was replaced by standard culture medium without drugs, to determine whether the cells would recover from drug treatment or not. After 3, 12 and 24 hours again the proliferation rate was determined.

\section{Clotting time assay.}

Clotting times were measured according to the method previously described by Van DamMieras (Van Dam-Mieras et al.1992). Briefly, BCE cells were cultured on gelatin coated 96-well strips (NUNC), and at confluency the endothelial cells were treated with the drugs (concentrations and incubation times as described in the proliferation assay).

Briefly, the media containing the drugs were removed from the endothelial cells. The cells were washed once in PBS and subsequently $100 \mu \mathrm{l}$ Michaelis buffer $(\mathrm{pH} \mathrm{7.4)}$ and $100 \mu \mathrm{l}$ proled human plasma were added to the wells. After $2 \mathrm{~min}$ incubation at $37^{\circ} \mathrm{C}$, $100 \mu \mathrm{l} \mathrm{CaCl} 2(0.033 \mathrm{M})$ was added and the coagulation time recorded.

Determination of the clotting time in collected supernatants from the BCE cell cultures treated with drugs was performed as follows: a sample of $100 \mu \mathrm{l}$ is taken from each culture and transferred into a 96-well culture plate (control is Michaelis buffer). The supernatants were subsequently incubated with $100 \mu \mathrm{l}$ pooled normal human plasma for 2 minutes at $37^{\circ} \mathrm{C}$, after which $100 \mu \mathrm{l} \mathrm{CaCl}(0.033 \mathrm{M})$ is added and the coagulation time recorded.

\section{Factor $X$ and $X a$ determination.}

In this assay the chromogenic substrate $\$ 2337$ was used to dertermine the amidolytic activity on endothelial cells (Van Dam-Mieras et al.1992). Briefly, after 48 hours the culture medium was removed, endothelial cells were washed once and factor $\mathrm{X}$ and $\mathrm{Xa}$ expression measured as follows:

\section{Factor $X$}

Per well $25 \mu \mathrm{l}$ RVV (Russell's Viper Venom; 1 vial containing $1 \mathrm{mg}$ factor $\mathrm{X}$ activating protein in $0.1 \mathrm{mmol} / \mathrm{l} \mathrm{NaCl}$, dissolved in $15 \mathrm{ml}$ destilled water $), 25 \mu \mathrm{l}$ trisbuffer $(0.05$ $\mathrm{mol} / \mathrm{l}, 20 \mathrm{mg} / \mathrm{l}$ polybrene, $\mathrm{pH} 7.8)$ and $25 \mu \mathrm{l} \quad \mathrm{CaCl}_{2}(0.01 \mathrm{~mol} / \mathrm{l})$ were added and the mixture was incubated for 15 minutes at $37^{\circ} \mathrm{C}$. Then $50 \mu \mathrm{l}$ of the chromogenic substrate $\$ 2337$ (1 vial containing $30 \mu \mathrm{mol} / 1$ dissolved in $20 \mathrm{ml}$ destilled water) was added to the well. After 60 minutes incubation at $37^{\circ} \mathrm{C}$ citric acid GR $(4 \%)$ was added and extinction measured at $405 \mathrm{~nm}$.

\section{Factor Xa}

Per well $50 \mu \mathrm{l}$ tris buffer $(0.05 \mathrm{~mol} / \mathrm{l}, 20 \mathrm{mg} / 1$ polybrene, $\mathrm{pH} 7.8)$ and $25 \mu \mathrm{l} \mathrm{CaCl}_{2}$ $(0.01 \mathrm{~mol} / \mathrm{l})$ were added and the mixture was incubated for 15 minutes at $37{ }^{\circ} \mathrm{C}$. Then 50 $\mu \mathrm{l}$ of the chromogenic substrate $\$ 2337$ (1 vial containing $30 \mu \mathrm{mol} / 1$ dissolved in $20 \mathrm{ml}$ destilled water) was added to the well. After 60 minutes incubation at $37^{\circ} \mathrm{C} 25 \mu \mathrm{l}$ citric acid GR (4\%) was added and the extinction was measured at $405 \mathrm{~nm}$. 
Statistical analysis.

Statistical analyses were performed by using the Wilcoxon-rank test.

\section{Results.}

As shown in figure 1, 5FU and CDDP were capable to inhibit endothelial cell proliferation significantly compared to controls.

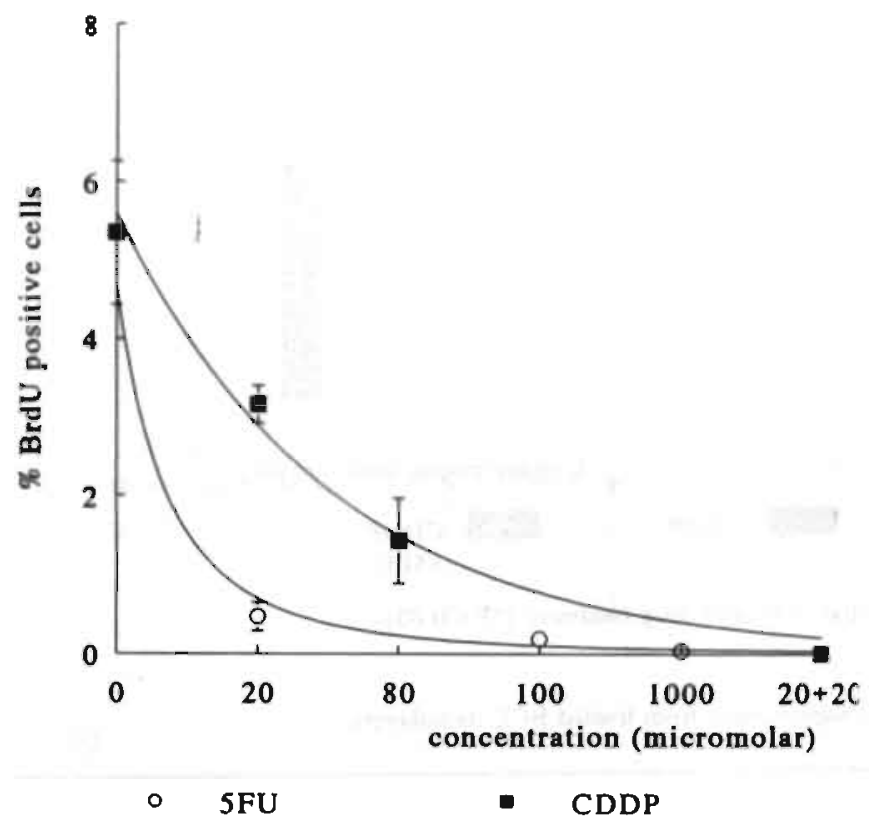

Figure 1. Proliferation rate of endothelial cells after 24 hour incubation with SFU or CDDP.

5FU was a more potent inhibitor than CDDP in similar concentrations. When a combination of 5FU and CDDP in low concentrations ( $20 \mu \mathrm{M}$ for each drug) was given, the proliferation rate decreased towards zero as well. Since cell death did not occur in the endothelial cells during the 24 hour treatment as determined by trypan blue exclusion, it was interesting to know whether the drugs forced the endothelial cells into a resting phase from which they could recover, or that the cells were in a sub-lethal phase only requiring prolongation of the drug treatment before cell death occured. No recovery of the cells was observed after 24 hours (data not shown), suggesting the cells were in a lethal arrest. Subsequently we investigated the effect of the drugs on the procoagulant response of endothelial cells. This response was assayed in two ways: 1) by measuring the clotting time on drug-treated endothelial cells and 2) by determining factor $\mathrm{X} / \mathrm{Xa}$ expression on drug treated endothelial cell. Results of the first assay are shown in figure 2. 


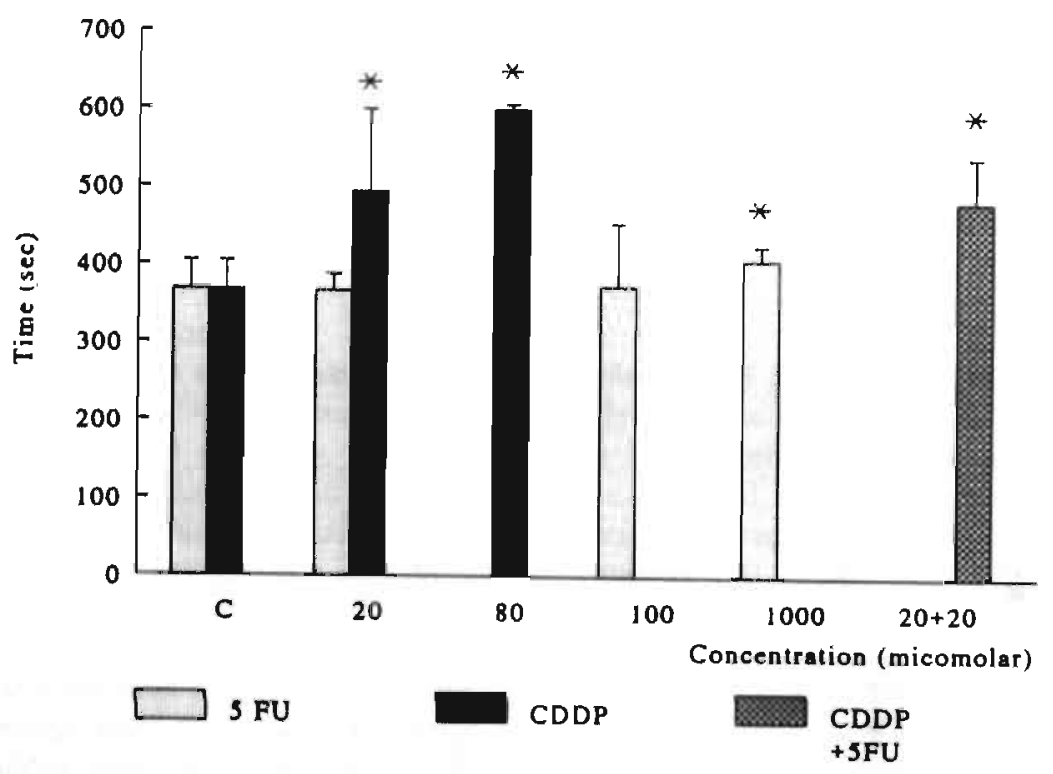

Figure 2. Clotting time on endothelial cells after drug treatment $\left({ }^{*} \mathrm{P}<0.05\right)$.

Table 1. Clotting time measured in supernatants from treated BCE monolnyers.

Treasment Time (sec) \pm s.d.

\begin{tabular}{ll}
\hline Michselis buffer & $220 \pm 25$ \\
$\alpha-\mathrm{MEM}+5 \%$ DCS (SMEM) & $213 \pm 43$ \\
$20 \mu \mathrm{M}$ SFU & $192 \pm 24$ \\
$100 \mu \mathrm{M}$ SFU & $186 \pm 13$ \\
$1000 \mu \mathrm{M}$ SFU & $191 \pm 34$ \\
$20 \mu \mathrm{M}$ CDDP & $214 \pm 13$ \\
$80 \mu \mathrm{M}$ CDDP & $268 \pm 46$ \\
$20 \mu \mathrm{M}$ SFU $+20 \mu \mathrm{M}$ CDDP & $198 \pm 21$ \\
\hline
\end{tabular}

Michaelis buffer whs used to determine the real clotting time of the plasma as used in this assay.

Only when high doses of $5 F U$ were used ( $1 \mathrm{mM}$ ), a slight delay of fibrin formation was found. CDDP however, already delayed fibrin formation at low doses; concentrations of 20 and $80 \mu \mathrm{M}$ CDDP significantly increased the clotting time (figure 2). This effect was 
also obtained when a combination of both $20 \mu \mathrm{M}$ 5FU and $20 \mu \mathrm{M}$ CDDP was used. When clotting times were measured in supernatants of drug-treated endothelial cells no effect was found, as shown in table 1.

The chromogenic assay used for factor $\mathrm{X}$ and $\mathrm{Xa}$ measurements (figure 3), revealed that the amount of factor $\mathrm{X} / \mathrm{Xa}(\mathrm{IU} / \mathrm{ml})$ on the endothelial cell surface after treatment with drugs for 24 hours did not differ from control values.

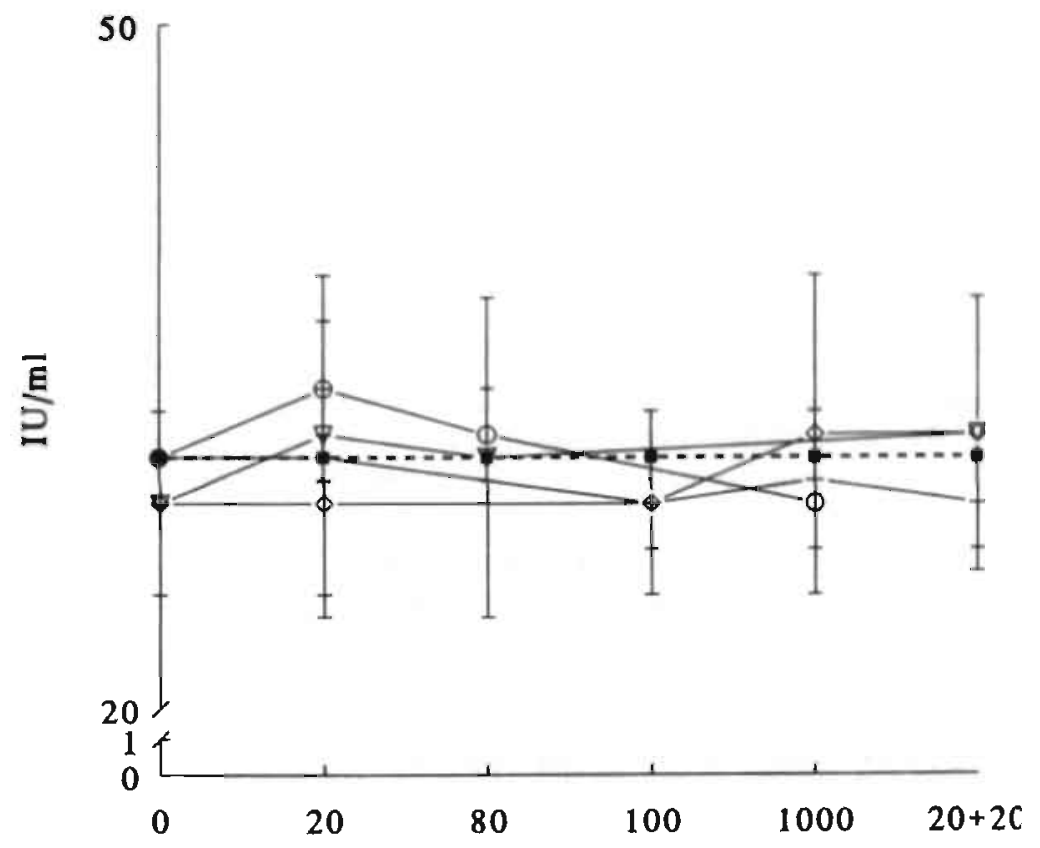

Figure 3. Factor $X$ expression on BCE treated with various concentrations of SFU $(+)$, CDDP $(0)$ and factor Xa expression on BCE treated with SFU $(\$)$ and CDDP $(v)$. Controls are non-treated BCE (D). No differences were detected.

Discussion.

Chemotherapy is targeted primarily towards malignant cells but can also exert toxic effects on other cells types. In case of endothelial cells these effects may either be desired (when the formation of new vessels is inhibited by the drug at the endothelial cell level) or not desired (when the endothelial cell becomes procoagulant, resulting in fibrin formation which indirectly supports angiogenesis).

In experiments on the role of endothelial cells in tumor angiogenesis in vivo, inhibition of proliferation of endothelial cells did not prevent the formation and outgrowth of new vessels (Sholly et al.1984). In spite of these findings, many angiogenesis factors appeared to induce endothelial cell proliferation as part of their activity (Bicknell \& Harris 1991, 
Folkman 1985). Our previous results showed enhancement of endothelial cell proliferation when these cells were cultured in tumor conditioned media from tumors under various culture conditions (Lichtenbeld \& Blijham 1992). A possible suseptibility of proliferating endothelial cells for agents such as 5FU and CDDP could be of interest as part of an antiangiogenic theory.

As far as the desired effects of the drugs are concerned, our present results showed that endothelial cell proliferation was inhibited after exposure to 5FU and CDDP for 24 hours in concentrations that could be achieved in human plasma during treatment (Borenfreund et al.1990, Etienne et al.1991). The endothelial cells did not appear to die immediately but merely were lethally arrested, since they were not able to resume DNA synthesis within the next 24 hours in normal culture medium.

Previously (Lichtenbeld et al.1993) we found that endothelial cells exerted procoagulant activity when cocultured with tumor cells. According to Dvorak (Dvorak 1986, Dvorak et al. 1987) this feature favors tumor growth and is therefore not desired in our antiangingenic theory.

The results of the clotting experiment showed that CDDP caused a dose dependent delay on fibrin formation (5FU only caused a slight delay at the highest concentration used).

This effect appeared to be cell-associated since no anti-coagulant effect could be detected in the supernatants of the drug-treated endothelial cells. At present we have no explanation for this delay in fibrin formation on drug treated endothelial cells as compared to non-treated endothelial cells. It is unlikely that it is related to the decrease in proliferative activity, since this effect occured with both drugs. 5FU had the most prominent effect and this agent hardly delayed the endothelial cell-associated fibrin formation.

Finally, combining the (preliminary) results obtained in this work, we could speculate that the endothelial cell damage due to 5FU and CDDP treatment, down-regulated all cell functions finally resulting in cell death. Whatever the explanation for this will be, the anti-coagulant activity is opposite to what is generally believed to be important in tumor angiogenesis; the formation of fibrin as a provisional matrix. High dose CDDP therefore could have a double anti-angiogenic effect by inhibiting peritumoral fibrin formation and endothelial cell proliferation. The results of our experiments also suggest that endothelial cell damage due to drugs probably do not contribute to the thromboembolic side effects that have been described after chemotherapy (Bertomeu et al.1990, Levine et al.1988).

More in vitro studies on the effects of chemotherapeutics on non-malignant cells might contribute to a better understanding of drug-treatment on neoplastic growth and might be beneficial for the development of improved antineoplastic interventions.

\section{References.}

Bertomeu MC, Gallo S, Lauri D, Levine MN, Orr FW, Buchanan MR. Chemotherapy enhances endothelial sell reactivity to platelets. Clin. Exp. Metastasis 8(6), 511-5518, 1990.

Bicknell R. Harris AL. Novel growth regulatory factors and tumour angiogenesis. Eur. J. Cancer 27(6). 785-789, 1991. 
Borenfreund E, Babich H, Martin-Alguacil N. Rapid chemosensitivity assay with human normal and tumor cells in vitro. In Vitro Cell. Dev. Biol. 26, 1030-1034, 1990.

Donati MB. Poggi A, Semeraro N. Coagulation and malignancy. In: Recent advances in blood coagulation. Poller L. Editor, Churchill Livingstone, New York, 375-391, 1981.

Dvorak HF. Tumons: wounds that do not heal. New Eng. J. Med. 315, 26, 1650-1659, 1986.

Dvorak HF, Harvey VS, Estrella P, Brown L, MeDonach J, Dvorak AM. Fibrin containing gels induce angiogenesis. Implications for tumor stroma generation and wound healing. Lab. Invest. 57, 673, 1987.

Etienne MC, Bernard S, Fischel JL, Formento P, Gioanni J, Santini J, Demard F, Schneider M, Milano G. Dose reduction without loss of efficacy for 5-fluorouracil and cisplatin combined with folinic acid, In vitro study on human head and neck carcinoma cell lines. Br. J. Cancer 63, 372-377, 1991.

Folkman J. Tumor angiogenesis. Adv. Cancer Res. 43, 175-203, 1985.

Levine MN, Gent M, Hirsch J, Arnold J, Goodyear MD, Hryniuk W, DePauw S. The thrombogenic effect of anti-cancer drug therapy in women with stage II breats cancer. New Eng. J. Med. 318, 404-407, 1988.

Lichtenbeid $\mathrm{HC}_{n}$ Blijham $\mathrm{GH}$. Tumor cell spheroids induce a mitogenic response in endothelial cells. Angiogenesis: Key principles, Science, Technology, Medicine. R. Steiner, PB Weisz and R. Langer, Eds. Birkhüuser Verlag Basel, 261-265, 1992.

Lichtenbeld HC, Muller AD, Van Dam-Mieras MCE, Blijham GH. Tumor spheroid induced vesicle formation on endothelial cells is associated with procoagulant properties. Eur. J. Cell Biol. Suppl.37, Vol. $60,69,1993$.

Loehrer PJ, Einhom LH, Williams SD, Hui SL, Estes NC, Pennington K. Cisplatin and 5-FU for the treatment of adenocarcinoma of the colon. Cancer Treat. Rep. 69, 1359, 1985.

O'Connell MJ, Moertel CG, Kvols LK. Clinical trial of cisplatin and intensive 5-fluorouracil for the treatment of advanced colorectal cancer. Am. J. Clin. Oncol. 9, 192-195, 1986.

Sholly MM, Ferguson GP, Seibel HR, Montour JL, Wilson JK. Mechanisms of neovascularization. Vascular sprouting can occur without proliferation of endothelial cells. Lab. Invest. 51, 624-632, 1984.

Sileni VC, Fosser V, Maggian P, Padula E, Beltrame M, Nicolini M, Arslan P. Pharmacokinetics and tumor concentration of intraarterial and intravenous cisplatin in patients with head and neck squamous cancer. Cancer Chemother. Pharmacol. 30, 221-225, 1992.

Thyss A, Schneider M, Santini J, Caldani C, Vallicioni J, Chauvel P, Demard F. Induction chemotherapy with cis-platinum and 5-fluorouracil for sqamous cell carcinoma of the head and neck. Br. J. Cancer 54, 755-760, 1986.

Van Dam-Mieras MCE, Muller AD, Van Hinsbergh VWM, Mullers WJHA, Bomans PHH, Bruggernan CA. The procosgulant response of cytomegalovirus infected endothelial cells. Thromb. Haemostas. 68(3) 364-370, 1992. 


\title{
Chapter 8.
}

\section{General Discussion.}

\author{
Curious: "why do birds fly south for the winter?" \\ Science: "Instinct."
}

The Tao of Poob, 1982.

It has been two decades since endothelial cells were first cultured. This ushered in a new era that allowed cellular and molecular ways of studying the angiogenic phenomenon (Jaffe et al.1973, Folkman et al.1979). During these years evidence was obtained that tumors were angiogenesis dependent (for a review see Folkman 1990).

In these experiments tumor conditioned media proved to be a rich source of both growth stimulating factors and angiogenic factors for endothelial cells (Beutler et al.1985, Fett et al.1985, Klagsbrun 1989, Levy et al.1989, Leung et al.1989). We used in our work venous (human umbilical vein) and capillary (bovine adrenal cortex) endothelial cells to test their proliferative response to tumor conditioned media from various colorectal tumor cell lines, i.e. SW480, SW620, CaCo2 and HT29 (Fogh \& Trempe 1975, Fogh et al.1977). The proliferation rate of the endothelial cells increased as expected, with differences depending on the tumor cell line used, i.e. $\mathrm{CaCo} 2$ induced a weaker response in endothelial cell proliferation than did tumor cell line HT29.

In vivo, the tumor is growing in a sphere-like nodule, compared to in vitro monolayer cultures. Sutherland developed a model for culturing sphere-like avascular tumor nodules, the tumor spheroid (Sutherland et al.1971, Sutherland 1981, 1988), which is employed in this study for medium conditioning. In building an in vitro model of tumor-associated angiogenesis this tumor spheroid-conditioned medium (TSCM) was used in the endothelial proliferation experiments. It was found that TSCM would stimulate the proliferation of endothelial cells more efficiently then the conditioned medium of the tumor cell monolayers. An inverse relationship was found between the age and size of spheroids and their ability to condition the medium for the activity leading to endothelial cell mitogenesis. Very young ( $<5$ days) tumor spheroids were the most mitogenic for both types of endothelial cells (see chapter 2 and 3 ).

To investigate other endothelial cell properties the study of the interaction of tumor cells with endothelial cells growing as tubular structures rather than monolayer cultures was begun. An in vitro model was used in which endothelial cell aggregates were embedded in a collagen type I matrix which stimulated endothelial sprout formation into tubular structures (Montesano 1992).

The previously described tumor spheroids (1-3 days) were added to the matrix and observed after 48 hours blebbing of the endothelial sprouts was observed (see chapter 4). 
These blebs resembled vesicles that are formed upon activation of erythrocytes and thrombocytes, although the observed vesicles were rather large $(0.5-2 \mu \mathrm{m})$. The formation of the vesicles of the other cell types has been associated with stimulatory events that induce a change in the asymmetric distribution of phospholipids over the cell membrane (Schroit \& Zwaal 1991). These membrane pertubations form vesicles that are procoagulant in nature, and can lead to fibrin formation.

It has been described by many groups (for a review see Machovich 1987) that fibrin deposits are found around tumors and that this could be benificial for the tumor (Dvorak et al.1987) by providing a provisional matrix in which tumor cells can grow and develop a vascular network. The latter aspect is crucial for succesful tumor growth (Folkman 1990). It has been suggested that this fibrin could protect the tumor nodule from the host defense mechanisms (Donati et al.1981). Understanding the aspects and mechanisms in tumor growth could lead to a more accurate approach for anti-neoplastic interventions.

In the coagulation cascade the intrinsic and extinsic pathway converge at the level of factor $X$, which then is activated to factor $\mathrm{Xa}$. We therefore measured factor $\mathrm{X} / \mathrm{Xa}$ expression, as described previously (Van Dam-Mieras et al.1992). In the cocultivation of the endothelial cell aggregates and tumor spheroids, a significantly increased expression in factor $X$ and $\mathrm{Xa}$ was detected (see chapter 4 ). We found some factor $\mathrm{X} / \mathrm{Xa}$ on both the endothelial aggregates and on the tumor spheroids when cultured individually, but the increase in factor $\mathrm{X} / \mathrm{Xa}$ in the cocultures was significantly higher than the sum of the individual values, suggesting an additional effect in the cocultures.

The most obvious cause for this increased factor $X$ would be the presence of Tissue Factor (TF) since it has been described that tumor cells can secrete tissue factor-like activity (Dvorak et al.1983). TF activates factor VII (factor VIla), thus forming a complex which either directly activates factor $\mathrm{X}$ to $\mathrm{Xa}$ (extrinsic pathway) or indirectly activates factor IX to IXa (intrinsic pathway), which in turn activates factor $\mathrm{X}$ to $\mathrm{Xa}$.

Anticipating on the dependency of the tissue factor-factor VII complex to activate factor $X$, we measured in our in vitro model of cocultured endothelial cell aggregates and tumor spheroids, the presence of factor VII/VIIa. No such activity could be detected, excluding tissue factor as the initiator of the factor $\mathrm{X}$ activation.

It has been described by Gordon that tumor cells themselves are capable to shed procoagulant vesicles (Gordon et al.1975, Gordon 1987, Gordon \& Mourad 1991). Gordon described a cancer procoagulant (CP) which activates factor X independently of tissue factor (Gordon et al.1975, Gordon 1987, Gordon \& Mourad 1991).

This cancer procoagulant is a cysteine protease in contrast with normal factors from the coagulation cascade which are serine proteases. Serine proteases have $\mathrm{OH}$-groups at the catalytic sites, while cysteine proteases have SH-groups at the catalytic sites. We investigated the effects of the $\mathrm{SH}$-inhibiting reagents $\mathrm{HgCl}_{2}$ and Iodacetamide on cocultures and measured factor $\mathrm{X} / \mathrm{Xa}$ expression. Both factor $\mathrm{X}$ as well as factor $\mathrm{Xa}$ were significantly reduced, which points to an inhibiting effect of SH-modification on the interacion of factor $\mathrm{X} / \mathrm{Xa}$ with the endothelial cell surface. It is too early to further speculate on these results. 
It has been suggested that tumor derived angiogenic factors (TAF) (Folkman 1990) could be responsible for the neovascularization. A wide variety of these factors have been isolated from an equal' variety of tumors, without a consistent pattern. We speculate that a more common mechanism underlies the initiation of tumor angiogenesis.

An intruiging and at first site unrelated aspect of tumors is the production of relatively large amounts of reactive oxygen intermediates. Tumors have a high ATP turnover and therefore might: easily generate oxidases, catalysing oxygen radical producing reactions (Harris et al.1992). It has indeed been found that tumors generate large amounts of hydrogen peroxides (Szatrowski \& Nathan 1991, Voest et al.1992). These compounds are considered to be involved in reversible and irreversible cell injury (for a review see Hiraishi et al.1992). Thus, tumor cells could easily affect endothelial cells by peroxidation of membrane phospholipids, proteins and DNA.

Endothelial cells have relatively large amounts of polyunsaturated fatty acids (PUFA) in their cell membrane which are good target molecules for reactive oxygen species. Endothelial cells have a relatively low catalase activity, and contain high amounts of ferritin, an important iron source that plays a role in lipid peroxidation (Dargel 1992). These aspects, make endothelial cells rather sensitive targets for peroxides. It is suggested that oxidative processes could indeed play a role in tumor induced endothelial cell activation.

In our experiments (see chapter 6) we observed similar vesicle formation on the endothelial cells upon stimulation with exogenously added peroxides as we found on the tumor spheroid stimulated endothelial cells. These vesicles proved to be procoagulant as well. This suggested that lipid peroxidation of endothelial cells might play a role in the induction of angiogenesis by tumor cells.

Shortly before the onset of the establishment of new capillaries, rather large numbers of mast cells accumulate around the tumor nodule (Blood \& Zetter 1990, Meininger \& Zetter 1992, Roche 1986). Mast cells have fascinated investigators since their initial definition by Ehrlich (Ehrlich 1879, for a review see Dvorak 1991). It has been suggested that tumors attract mast cells by generating chemotactic factors and that mast cells, once present at the tumor site, support tumor growth and stimulate angiogenesis (Dabbous 1986, Blood \& Zetter 1990). It has also been reported that mast cells are cytoloxic for tumors (Burtin et al. 1985). To obtain further insight in the role of mast cells in the angiogenic phenomenon (in particular the effect on the endothelial cell), we investigated the effects of mast cell lysate on endothelial cells, as well as the effects of cocultivation of mast cells with endothelial aggregates. The results showed that mast cells contributed to the procoagulant state of endothelial cells once mast cells became associated with the endothelial cell. When no cell association occurred, the mast cell lysate proved to be: extremely anticoagulant. This paradox became even more complex when tumor cells were: added to the in vitro assay in which endothelial aggregates, tumor spheroids and mast cells were cocultured. As described earlier, the procoagulant response, expressed as factor $\mathrm{X}$ activation, increased upon tumor stimulation. Mast cells could induce similar effects as tumor spheroids, however with the striking difference that this increase could no longer be inhibited by an anti-X antibody, as could be done in the case of tumor cells. It could be speculated that a conformational change in factor $\mathrm{X}$ protein structure could 
occur under the influence of mast cell derived compounds.

Finally, two of the currently used anti-cancer drugs, 5-fluorouracil (5FU) and cisplatin (CDDP) were tested in our proliferation and coagulation assays in order to obtain information on their effects on non-malignant endothelial cells and a possible antiangiogenic potency. Endothelial cells treated with drugs showed an inhibited proliferation rate, a prolonged clotting time and an unchanged factor $\mathrm{X} / \mathrm{Xa}$ expression. In the conditioned media from these cultures (in which the chemotherapeutic drugs are present) we did not detect an effect. These results do not support the idea that chemotherapeutic drugs enhance the angiogenic features of the endothelial cell, a mechanism that has been suggested to underly the increased incidence of thromboembolism observed with chemotherapy; the agents however, may have anti-angiogenic properties that should be investigated further.

Based on our study it is possible to hypothesize the following mechanism by which tumor derived oxidants and growth factors might contribute to angiogenesis. First the endothelial cell is oxidatively triggered by the tumor cells leading to lipid peroxidation of the membrane and vesicle formation. Second, this creates a procoagulant response that could lead to the formation of a fibrin network that supports tumor growth and tumor angiogenesis. Subsequently the growth factors generated by the tumor cells will support the proliferation of endothelial cells and the establishment of new capillaries.

Mast cells may contribute to the second, fibrin generating step in this process.

It would be interesting to test this hypothesis, for instance by investigating whether a relationship exists between the amount of peroxides generated by tumors, their fibrin content and the extent of tumor-associated neovascularization.

Finally, it may be that chemotherapeutic agents not only inhibit tumor cell growth, but also interfere in this angiogenic process.

\section{References.}

Beutler B. Mahoney J, Le Trang N, Pekala P, Cerami A. Purification of cachectin, a lipoprotein lipasesuppressing hormone secreted by endotoxin-induced RAW 264.7 cells. J.Exp. Med. 161 (5), 984-995, 1985.

Blood C. Zetter, B. Tumor interactions with the vasculature: angiogenesis and tumor metastasis. Biochem Biophys Acta 1032, 89-118, 1990.

Burtin C. Ponvert C. Fray A, Scheinmenn P, Lespinats G, Loridon B, Canu P, Paupe J. Inverse correlation between tumor incidence and tissue histamin levels in $W / W v, W v / t$ and $+/+$ mice. J. Natl. Cancer Inst. $74,671-674,1985$

Dabous M, Walker G, Haney L, Carter N, Nicholson G, Woolley D. Mast cells and matrix degradation at sites of tumour invasion in rat mammary edenocarcinoma. Br. J. Cancer 54, 459-465, 1986.

Dargel R. Lipid peroxidation - common pathogenic mechanism? Exp Toxic Pathol 1992, 44, 169-181. 


\section{8}

Donati MB, Poggi A, Semeraro N. Coagulation and malignancy. In: Recent advances in blood coagulation. Poller L. Editor, Churchill Livingstone, New York, 375-391, 1981.

Dvorak, AM. Blood cell biochemistry. Basophil and mast cell degranulation and recovery. Volume 4. Plenum Press, New York 1991.

Dvorak H, Van de Water L, Bitzer A, Dvorak A, Anderson D. Harvey V, Bach R, Davis G, DeWolf W, Carvalho A. Procoagulant activity associated with plasma membrane vesicles shed by cultured tumor cells. Cancer Res. 43(9), 4334-4342, 1983.

Dvorak HF, Harvey VS, Estrella P, Brown L, MeDonaclh J. Dvorak AM. Fibrin containing gels induce angiogenesis. Implications for tumor strom generation and wound healing. Lub. Invest, 57, 673, 1987.

Ehrlich P. Beitnge zur Kenntniss der Granulierten Bindegewebsze. Arch. Anat. Physiol. Abteilung 3, 166$169,1879$.

Fett JW, Strydom DJ, Lobb RF, Alderman EM, Betheme JL. et al. Isolation and characterization of angiogenin an angiogenic protein from human carcinoma cells. Biochem. 24, 5480-5486, 1985.

Fogh J. Trempe P. New human tumor cell lines. In Human tumor cells in vitro, New York Plenum Press. Editor J. Fogh, 1975.

Fogh J, Fogh JM, Orleo T. One hundred and twenty seven cultured human tumor cell lines producing tumors in nude mice. J. Natl. Cancer Inst.59, 221-226, 1977.

Folkman J, Haudenschild C, Zetter B. Long-term culture of capillary endothelial cells. Proc. Natl.Acad.Sci.U.S.A. 76, 5217, 1979.

Folkman J. What is the evidence that tumors are angiogenesis dependent? J.Natl.Cancer Institute Vol.82. No. 1; 4-6, 1990.

Gordon SG, Franks JJ, Lewis B. Cancer procosgulant A: a factor $\mathrm{X}$ activating procoagulant from malignant tissue. Thromb. Res. 6, 127, 1975.

Gordon SG. Cancer Procoagulant. In: Hemostasis and Cancer. Laszlo Muszbek Editor, CRC Press Inc. Boca Raton, Florida; 4-14, 1987.

Gordon SG, Mourad AM. The site of activation of fuctor $\mathrm{X}$ by cancer procoagulant. Blood Coagul. Fibrinolysis. 2 (6), 735-739, 1991.

Harris M, Schiller H, Reilly P, Donowitz M, Grisham M, Bulkley G. Free radicals and other reaetive oxygen metabolites in inflammatory bowel disease: cause, consequence or epiphenomenon? Pharm. Ther. $53,375-408,1992$.

Hiraishi H, Terano A, Razandi M, Sugimoto T, Harada T, Ivey K. Role of cellular superoxide dismutase against reactive oxygen metabolite injury in cultured bovine aortic endothelial cells. J Biol Chem 267, 21 , 14812-14817, 1992.

Jaffe EA, Nachman RL, Becker CG, Minick CR. Culture of human endothelial cells derived from umhilical veins. J.Clin.Invest. 52, 2745, 1973.

Klagsbrun M. The fibroblest growth factor family: structural and biological properties. Progress in Growth 
Factor Research Vol.1 207-235, 1989.

Leung DW, Cachianes G, Kuang WJ, Goeddel OV, Ferrara N. Vascular endothelial growth factor is a secreted angiogenic mitogen. Science 246, 1306-1309, 1989.

Levy AP. Tamarco R, Brem H, Nathans D. An endothelial cell growth factor from the mouse neuroblastome cell line NB41. Growth Factors 2 (1), 9-19, 1989.

Machovich R. Role of blood coagulation-fibrinolytic system and endothelial cells in malignancy. In: Hemaostasis and cancer. Lazjo Muszbeck Editor, CRC Press Inc. Boca Raton Florida; 4-14, 1987.

Meininger CJ, Zetter BR. Mast cells and angiogenesis. Semin. Cancer Biol. 3(2), 73-79, 1992.

Montesano R. Regulation of angiogenesis in vitro. 1992 Mack Forster Award Lecture. Eur. J. Clin. Invest. 22, 504-515, 1992.

Roche WR. The nature and significance of tumour-associated mast cells. J. Pathol. 48, 175-182, 1986.

Schroit AJ, Zwal RFA: Transbilayer movement of phospholipids in red cell and platelet membranes. Biochem. Biophys. Act 107, 313-324, 1991.

Stringer MD, Gorog PG, Froeman A, Kakkar VV. Lipid peroxides and atherosclernsis. Brit. Med. J. 298. 281-284, 1989 .

Sutherland RM, McCredie JA, Inch WR. Growth of multicell spheroids as a model of nodular carcinomas. J.Natl. Cancer Inst. 46, 113-120, 1971

Sutherland RM. Cell and environmental interactions in tumor microregions. The multicell spheroid model. Science 240,177-184, 1981.

Sutherland RM. Spheroids in cancer research. Cancer Res. 41, 2980-2984, 1988.

Van Dam-Mieras, M.C.E., Muller, A.D., Van Hinsbergh, V.W.M., Mullers, W.J.H.A., Bomans, P.H.H., Bnggeman, C.A. The procoagulant response of cytomegalovirus infected endothelial cells. Thromb. Heemostas. 68(3), 364-370, 1992.

Voest B, Van Fassen E, Van Asheck B, Neijt J, Marx J. Increased hydrogen peroxide concentration in human tumor cells due to a nitroxide free radical. Biochem. Biophys. Acta 1136, 113-118, 1992.

Szatrowski T, Nathan C. Production of large amounts of hydrogen peroxides by human tumor cells. Cancer Res. 51, 794-798, 1991. 


\section{Summary}

Growing tumors remain small until the onset of neovessel formation. This process of tumor vascularization (tumor angiogenesis) is investigated in an in vitro model in this thesis. Tumor angiogenesis can be classified roughly into three main features, endotheliai cell proliferation, activation and migration in response to tumor cells. To evaluate these aspects of the angiogenic phenomenon we developed an in vitro model as described in this work. In chapter 1 an overview is given of the current knowledge on tumor angiogenesis and the scope of the study including a brief outline of the work. Chapter 2 describes the development of an in vitro proliferation assay in order to study the proliferative response of endothelial cells (human umbilical vein (HUVEC) and bovine adrenal cortex capillary (BCE) endothelial cells) after exposure to turnor cells. We compared the mitogenic effect of conditioned medium from tumor cells cultured as monolayers to that of tumor cells cultured as avascular spheroids (colorectal tumor cell lines HT29, SW620, SW480 and $\mathrm{CaCo2}$ ). It was found that conditioned media of the spheroid cultures were significantly more mitogenic to endothelial cells than that of monolayer cultures. Furthermore an inverse relationship was found for the mitogenic effect of the tumor conditioned medium and the age of the spheroids that conditioned the medium. The more mature the spheroids were, the less mitogenic the conditioned medium (chapter 3). In order to investigate the activation and migration aspects in the angiogenic process, we developed a model based on a previously described collagen type I matrix model. In this model (chapter 4), endothelial cells were allowed to aggregate before embedding in a collagen gel. After 24 hours the aggregates had formed sprouts. These sprouts contained a lumen that was lined with endothelial cells. When tumor spheroids were introduced in this model, the length of the sprouts was not affected but extracellular vesicle-like structures were seen on the endothelial cell sprouts. The vesicles formed on endothelial cell sprouts upon coculturing with tumor spheroids, resembled the vesicles that were formed on erythrocytes and thrombocytes upon activation. The vesicles formed on erythrocytes and thrombocytes were procoagulant in nature leading to the formation of fibrin. The vesicles formed on endothelial cell sprouts upon stimulation with tumor spheroids exhibited also procoagulant activity since an increased amidolytic activity towards chromogenic substrate \$2337 was detected. This amidolytic activity was identified as factor $\mathrm{X}$, using antibodies against factor $\mathrm{X}$, that could inhibit factor $\mathrm{X} / \mathrm{Xa}$ expression. The activity was independent of tissue factor and could be blocked by $\mathrm{HgCl}_{2}$ and Iodoacetamide, which points to the involvement of SH-groups.

In the tumor bed fibrin deposits are found. The findings in our experiments could lend support for the hypothesis that tumors induce fibrin (formation) in order to create a provisional matrix in which the tumor can expand itself. Furthermore, it is thought this fibrin protects the tumor nodule from host defence mechanisms.

In an attempt to obtain information on the compound/agent(s) from the tumor that could be responsible for the induction of the procoagulant response in the endothelial cells, we investigated in chapter 5 the effect of exogenously added peroxides on endothelial cells, 
since it has been found that tumors secrete large amounts of reactive oxygen species like peroxides. Subsequently the formation of vesicles and the procoagulant response of endothelial cells upon activation by the peroxides was evaluated.

The results indicated that treatment of endothelial cells with peroxides induced the formation of similar vesicles on the endothelial cells and increased the procoagulant response as well. These effects were time and dose-dependent and could be inhibited by the anti-oxidant $d$ - $\alpha$-tocopherol (vitamin E). These findings suggested a possible role for reactive oxygen species in the angiogenic process in tumors, since reactive oxygen species are properties shared by many tumors.

Another aspect in (tumor) angiogenesis is the presence of mast cells. Shortly before the onset of the angiogenic process mast cells accumulate around the tumor nodule. Therefore we added mast cells (rat peritoneal mast cells) to our matrix model (in which already endothelial cell aggregates and tumor spheroids were present) as is described in chapter 6 , and evaluated their effect on the vesicle formation and procoagulant response of the endothelial cells. Also the effect of mast cell lysates was tested on the proliferation of endothelial cells. Mast cell lysate induced a dose-related stimulating effect on the proliferation of endothelial cells. Mast cell lysates strongly inhibited thrombin activity, comparable to the effect of the known anti-thrombotic combination of heparin plus antithrombin III. Mast cell lysates accelerated the formation of fibrin on endothelial cell monolayers and upon addition of mast cells to endothelial cell aggregates in the matrix model, a procoagulant activity was detected. Both tumor cells and mast cells led to the enhanced expression of factor $\mathrm{X} / \mathrm{Xa}$, but in case of mast cells, $\mathrm{Xa}$ was preferentially expressed at the expense of factor $X$, and moreover this expression could no longer be blocked by a specific anti- $X$ antibody, suggesting a conformational change of factor $X$.

In chapter 7, two commonly used chemotherapeutic agents (5-fluorouracil and cisplatinum) in cancer treatment, were introduced to endothelial cells. These agents inhibited endothelial cell proliferation and caused a dose dependent delay in fibrin formation, which appeared to be cell associated. No differences were detected in factor $\mathrm{X} / \mathrm{Xa}$ expression on endothelial cells treated with the drugs. These preliminary results suggest that more studies on the effects of chemotherapeutic drugs on endothelial cells could provide information on possible dualistic effects of the drugs as proliferation inhibitors as well as anti-angiogenic agents. This may contribute to a better understanding of drug-treatment on neoplastic growth and therefore improve antineoplastic interventions.

Based on the results from this work, we suggest a mechanism in tumor angiogenesis (chapter 8 ). First the endothelial cell is either directly or indirectly oxidatively triggered by tumor cells, leading to lipid peroxidation of the cell membrane resulting in vesicle formation. Second, this creates a procoagulant response that could lead to the formation of fibrin which supports tumor growth, angiogenesis and protects the tumor nodule from the host immune system. At this point, mast cells could play a regulating role in fibrin formation. Subsequently, growth factors generated by the tumor as well, will support further establishment of a capillary network in the tumor. 


\section{Samenvatting.}

Het is gebleken dat tumoren klein en relatief ongevaarlijk blijven zolang er geen neiwerk van bloedvaten aariwezig is. Het proces waarbij de tumor een vaatbed induceert, tumor angiogenese, wordt in dit proefschrift onderzocht met behulp van een in vitro model. Nieuwe bloedvaten worden door de tumor uit bestaande bloedvaten van de gastheer gerecruteerd. Hiertoe worden endotheelcellen van bestaande vaten geaktiveerd waarna vervolgens de endotheelcel migreert (zich verplaatst) en prolifereert (zich vermenigvuldigt). Om deze parameters onder invloed van de tumor nader te bestuderen wordt een in vitro model beschreven waar de endotheelcel en de tumorcel zijn samengebracht.

In hoofdstuk 1 wordt een overzicht gegeven van de huidige stand van zaken met betrekking tot tumor angiogenese. Ook worden het doel en een kort overzicht van de opzet van de studie gegeven. Hoofstuk 2 beschrijft de ontwikkeling van een in vitro proliferatie model waarin de proliferatieve reactie van de endotheelcel (humane veneuze navelstreng endotheelcellen (HUVEC) en runder bijnierschors capillair endotheel (BCE) cellen) op de aanwezigheid van tumurcellen bestudeerd wordt. Het mitogene (proliferatiestimulerende) effect van geconditioneerd medium afkomstig van tumorcellen gekweekt als monolaag wordt hierbij vergeleken met geconditioneerd medium afkomstig van tumor cellen gekweekt als sferoiden. Gebruik wordt gemaakt van de colorectale tumor cellijnen SW620, SW480, HT29 en CaCo2. Gevonden is dat geconditioneerd medium afkomstig van sferoiden significant sterker mitogeen is dan geconditioneerd medium afkomstig van tumoren gekweekt in monolagen. Een omgekeerd evenredige relatie werd gevonden tussen het mitogene effect van het tumor geconditioneerde medium van sferoiden en de leeftijd van deze sferoiden. Hoe ouder de sferoiden, hoe minder mitogeen het geconditioneerde medium (hoofstuk 3).

Om de parameters activatie en migratie van het angiogenetische proces te bestuderen wordt een gemodificeerd model beschreven gebaseerd op een matrix model. Hierbij wordt gebruik gemaakt van de matrix component collageen type I. In dit model (hoofstuk 4) worden endotheelcellen zodanig gekweekt dat ze gaan aggregeren. Vervolgens worden deze aggregaten in de collageen matrix ingebed en treedt er na verloop van tijd vorming van tubulaire (buis) strukturen op, zgn. spruiten. Deze spruiten bevatten cen lumen (holte) die bekleed is met endotheelcellen. Wanneer aan dit systeem tumor sferoiden worden toegevoegd blijkt dat geen invloed op de lengte maar wel op de morfologic van de spruiten te hebben. Extracellulaire vesikel-achtige (bolletjes) strukturen worden waargenomen. Deze vesikels lijken sterk op vesikels die gevormd worden op thrombocyten en erythrocyten nadat deze zijn geaktiveerd. De vesicles op thrombocyten en erythrocyten zijn procoagulant (stolaktief), wat uiteindelijk zal resulteren in de vorming van fibrine. De vesicles zoals die gevonden worden op de endotheelcellen naúat deze geaktiveerd zijn door tumorcellen vertonen een toegenomen activiteit voor het chromogeen substraat S2337. Deze aktiviteit werd geỉdentificeerd (met behulp van cen 
antilichaam) als factor $\mathrm{X}$. Dit antilichaam kan zowel factor $\mathrm{X}$ als de geaktiveerde vorm $X a$, remmen. Deze procoagulant aktiviteit blijkt onafhankelijk van Weefsel Factor (Tissue Factor) te zijn en kan geblokkeerd worden door $\mathrm{HgCl}_{2}$ en Iodoacetamide, hetgeen betekent dat SH-bindingen betrokken zijn bij deze vorm van aktivatie.

In vivo wordt in en rond tumoren fibrine waargenomen. Deze waarneming en de bovenbeschreven resultaten m.b.t. de procoagulant reaktie van de endotheelcel na aktivatie onder invloed van tumor sferoiden, zijn mogelijk met elkaar in overeenstemming. De hypothese bestaat dat tumoren in staat zijn de vorming van fibrine te induceren. Dit zou als voordeel voor de tumor kunnen hebben dat de fibrine enerzijds als tijdelijke matrix gebruikt kan worden om in te groeien en anderzijds als beschermmantel tegen de immuunrespons (afweer) van de gastheer.

Experimenten om inzicht te krijgen in een mogelijk mechanisme dat door de tumor gebruikt kan worden om de procoagulant respons van de endotheel cel te induceren, wō̄llen in hoofstuk 5 beschreven. Hiertoe wordt uitgegaan van het gegeven dat peroxides in relatief grote hoeveelheden door tumoren worden gegenereerd. In de beschreven experimenten worden peroxides toegevoegd aan de endotheelcel aggregaten en deze aggregaten worden vervolgens geeevvalueerd op de vorming van vesicles en op een toename in procoagulant aktiviteit. De resultaten laten zien dat inderdaad vesicles worden gevormd en dat de procoagulant aktiviteit stijgt onder invloed van peroxides. Deze effecten blijken zowel dosis- als tijdsafhankelijks en kunnen worden geremd door $d$ - $\alpha$-tocopherol (vitamine E). Deze gegevens ondersteunen het idee dat peroxides een rol zouden kunnen spelen in het angiogenetisch proces in tumoren.

Een ander fenomeen dat wordt waargenomen bij tumor angiogenese is de aanwezigheid van grote aantallen mestcellen vlak voor de eigenlijke angiogenese optreedt. Hoofstuk 6 geeft de resultaten weer van de experimenten waarbij mestcellen (peritoneale rattemestcellen) worden toegevoegd aan de eerder beschreven modellen. Ook wordt het effect van mestcel lysaat geẻvalueerd op de thrombine activiteit. Mestcel-lysaat stimuleert (dosis-afhankelijk) endotheelcel proliferatie. Mestcel-lysaat blijkt een sterke remmer van thrombine aktiviteit. Dit effect ligt in dezelfde orde-grootte als dat van het bekende antistolcomplex heparine plus antithrombine III. Dit complex kan door polybreen geremd worden, echter het anti-stol effect dat door mest cellysaat wordt veroorzaakt kan slechts gedeeltelijk door polybreen geremd worden. Mestcel-lysaat versnelt significant de vorming van fibrine, zoals gemeten op endotheelcel monolagen. Na toevoeging van mestcellen aan het matrix model wordt ook hier een procoagulante aktiviteit waargenomen. Zowel de tumorcellen als de mestcellen veroorzaken een verhoogde expressie van factor $\mathrm{X} / \mathrm{Xa}$ op de endotheel cellen, maar in het geval van de mestcellen blijkt factor Xa bij voorkeur tot expressie te worden gebracht, ten koste van factor X. Opmerkelijk hierbij is het feit dat de factor $\mathrm{X} / \mathrm{Xa}$ expressie niet langer geremd kan worden door anti-X antilichaam, wat zou betekenen dat een conformatie verandering in de structuur van factor $X$ is opgetreden.

In hoofstuk 7 worden twee cytostatica (5-Fluorouracil en Cisplatinum), die bij behandeling van colonkanker gebruikt worden, getest op hun effect op endotheelcellen. De cytostatica veroorzaken een significante proliferatie remming en een dosis afhanklijke vertraging in fibrine vorming. Op de behandelde endotheelcellen worden geen verschillen waargenomen in factor $\mathrm{X} / \mathrm{Xa}$ expressie. Deze resultaten, hoewel prematuur, ondersteunen 
het idee dat het: zinvol is om cytostatica te testen op een mogelijk dualistisch effect. Niet alleen.zouden cytostatica een anti-proliferatieve werking hebben op de tumorcel, maai mogelijk ook een antiangiogene werking via de endotheelcel. Meer inzicht zou kunnen bijdragen tot een beter begrip en een gerichtere aanpak in de behandeling van kanker.

In hoofstuk 8 tensiotte, wordt op grond van de resultaten zoals uit dit onderzoek verkregen zijn, een hypothetisch mechanisme voor tumor angiogenese voorgesteld. Hierbij wordt uitgegaan van het feit dat de produktie van peroxides een eigenschap is die door alle tumoren wordt gedeeld. De endotheelcel wordt door de peroxides van de tumor (al dan niet direkt) geaktiveerd wat leidt tot lipid-peroxidatie van de membraan (imembraan verstoringen), met als gevolg dat vesicle-formatie optreedt. Vervolgens ontstaat een procoagulant situatic welke uiteindelijlk tot de vorming van fibrine kan leiden. Mestcellen spelen vermoedelijk een regulerende rol in dit proces van fibrine vorming. Fibrine ondersteunt tumorgroei en tumorangiogenese. Tenslotte zullen faktoren zoals onder andere cytokinen en groeifaktoren afkomstig van de tumor "bijdragen tot de volledige ontwikkeling van een capillair netwerk dat vervolgens een essentiële rol speelt bij het ontstaan van de twee typische kenmerken van maligniteit (kwaadaandigheid) invasieve groei (binnendringen in weefsels) en metastasering, (uitzaaiing). 


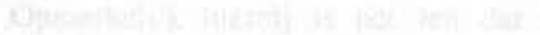

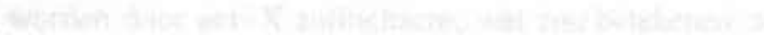

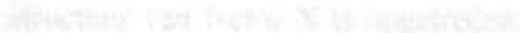

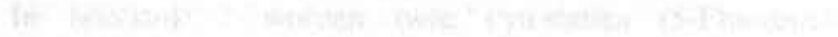

-

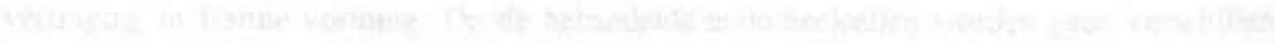

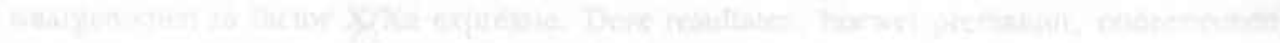




\section{Nawoord}

Het is een algemeen bekend feit dat de meeste personen die een proefschrint krijgen, slechts het curriculum vitae, het nawoord en eventueel nog de nederlandse samenvatting tezen. Ondanks dat dit wat negatief klinkt, is dit juist een aanleiding (tenminste in mijn geval) om wat extra aandacht aan deze drie onderdelen te besteden.

De periode waarin dit proefschrift tot stand is gekomen bestaat uit twee delen. De cerste twee jaar, 1989 en 1990, speelden zich af in het Biomedisch Centrum (BMC) achter het Ziekenhuis Annadal, bij de vakgroep pathologie. In de daarop volgende twee jaar, 1991 en 1992 (en nog een klein stukje van 1993) was het nieuwe Academische Ziekenhuis Maastricht (AZM) de plaats van handelingen. Daar kregen we (medewerkers van het uncologisch onderzoek van interne geneeskunde) een eigen lab tot onze beschikking, wat zijn invloed heeft doen gelden op de ontwikkeling van dit proefschrift.

De vakgroep interne geneeskunde is in de kliniek weliswaar cen grote vakgroep, maar wat betreft research-activiteiten is het allemaal nog zeer bescheiden. Zeker toen ik als AIO begon in 1989. Bert Schutte en Michèle Geebelen-Reynders waren degenen die, ingebed in de vakgroep pathologie, verantwoordelijk waren voor de lab-activiteiten. Zonder hun enthousiasme en inzet zou ik helemaal nooit als AIO bij interne zijn begonnen. Van beiden heb ik, behalve vele technische aspecten, vooral geleerd vertrouwen te krijgen in mijn eigen werk. Een ander, niet te onderschatten aspect daarbij was de gezelligheid in hun lab.

Zoals ik al schreef waren de lab faciliteiten van inteme ingebed in die van de vakgroep pathologie. Van deze vakgroep wil ik dan ook graag iedereen bedanken die daar toen werkzaam was en mij adviezen, hulp of anderszins heeft gegeven en zeker ook voor de prima werksfeer die zij met $z$ 'n allen creëerden. Toch wil ik graag een paar personen apart noemen.

Cor Beek wil ik bedanken voor de prima samenwerking en zijn engelen geduld bij het oplossen van (met name) mijn computer-problemen, zelfs als die niet direkt betrekking op mijn werk hadden. Ook wil ik Cor bedanken voor zijn hulp bij de verhuizing naar het nieuwe ziekenhuis. Mat Rousch wil ik bedanken voor zijn geduldige hulp en adviezen bij mijn "kleur- en kweek-escapades". Edith van de Linden wil ik danken voor haar hulp en onverwoestbare doortastendheid. Deze drie personen Cor, Mat en Edith zijn tevens wandelende databases, want altijd wist cen van hen wel waar ik iets kon vinden of bestellen. Dit heeft veel zinloos tijdverlies voorkomen.

Joop ten Kate en Ton de Goey, "oude rotten" in het vak, wil ik bedanken voor hun discussies, suggesties en adviezen betreffende mijn onderzoek en de opzet daarvan.

Tenslotte wil ik Winand Dinjens bedanken voor zijn hulp, ideëen en onuitputtelijk optimisme bij het uitvoeren van onze experimenten. Dat het lot hem zo zwaar heeft getroffen vind ik onbegrijpelijk en ik wens hem veel kracht voor de toekomst.

Zoals in dit proefschrift wordt beschreven (en voor degenen die dat nog niet hadden ontdekt), zijn endotheelcel-kweken de basis van mijn werk. Om deze cellen uit

* naar: Kramer Books, Dupont Circle, Washington DC, U.S.A. 1989. 
navelstrengen geïsoleerd te krijgen en vervolgens fatsoenlijk verder te kweken, heb ik geweldige hulp (en materialen) van Trudy Jeunehomme en Jet Leeuwenberg van de vakgroep heelkunde gekregen. Daarvoor ben ik beiden zeer dankbaar. Wim Buurman, hoofd van het immunologisch lab van deze vakgroep, wil ik ook bedanken voor zijn stimulerende discussies.

Dat het kweken van deze endotheelcellen niet van een leien dakje ging, mag blijken uit het feit dat ook Chris Reutelingsperger van de vakgroep biochemie zijn bijdrage heeft geleverd aan mijn kweeklessen.

Pas later ontdekte ik dat er ook relatief eenvoudig te kweken endotheelcellen bestonden.

I am very grateful to Dr. Martha Furie, dept. pathology, University of Stony Brook, Stony Brook NY, USA, who repeatedly and without any obligations supplied me with fresh endothelial cells. At the lab of Dr. Roberto Montesano and Dr. Michael Pepper, dept. pathology, CMU Genève, Switzerland, I was tought how to handle the endothelial cells properly. I wish to thank both of them for their kind help and suggestions.

$\mathrm{Na}$ de verhuizing in januari 1990 had interne een eigen oncologisch lab. Er stond nog wel niks in, maar dat kon worden gekocht. Met onvoorwaardelijke inzet en doortastendheid van Susan Joosten-Achjanie en Annick Peeters-Haesevoets hadden we in korte tijd het lab draaiende. Het zijn twee geweldige mensen met wie het een plezier is om samen te werken. De andere twee dames van ons lab, Monique Tinnemans en Marie-Hélène Lenders hebben, ondanks hun stationering elders de laatste twee jaar, zeker bijgedragen aan de prima werk sfeer.

In de nieuwe situatie nam mijn onderzoek ook een nieuwe wending. Een intensieve samenwerking met Rietje van Dam-Mieras van de Open Universiteit in Heerlen, Puck Muller en Rence Vossen van de vakgroep biochemie van de RL, kwam tot stand.

Door het overweldigende enthousiasme van Rietje kwam mijn onderzoek in een stroomversnelling. Rietje is iemand die veel leest, veel weet en met al die kennis bijzonder creatief kan omgaan. Zo ontstaan nieuwe invalshoeken met vaak verrassende resultaten. Dit heeft mij enorm gestimuleerd en doet dat nog steeds en ik hoop dat dat ook zo zal blijven. Haar bijdrage aan dit proefschrift is essentieel geweest. De benoeming van Rietje tot hoogleraar in het afgelopen jaar, kwam dan ook op een prima tijdstip want vanaf dat moment had ik cen tweede promotor.

Van biochemische bepalingen wist ik niet zóveel, maar Puck Muller des te meer. Behalve dat ze uitstekend experimenten kan aanpassen aan de vraagstelling, heeft ze ook gouden vingers voor de uitvoer ervan. Mede dankzij haar hebben we in zo korte tijd zoveel kunnen bereiken. Puck is een verrassende persoonlijkheid en een geweldige reisgenoot en kan aanleiding geven tot hilarische situaties.

In Renée Vossen heb ik een lotgenoot en vriendin gevonden. Dat dit ook tot gemeenschappelijke artikelen zou leiden is een bevestiging van de optimale samenwerking. Ik hoop dat in de toekomst ons contact, ondanks de afstand, blijft bestaan.

Door de nieuwe aanpak van mijn onderzoek, moest ik ook nieuwe dingen leren, zoals het isoleren van mestcellen uit ratten. Daarbij ben ik geholpen door een aantal mensen die ik hier ook wil bedanken, want hun hulp was onontbeerlijk. Allereerst Charles van Haaster 
en Paul Lemmens van het Cardiovasculair Research Instituut Maastricht (CARIM), die mij geheel belangeloos geleerd hebben hoe ik de isolaties moest doen. Toen ik vervolgens met eigen ratten aan de slag ging, heb ik daarbij prima hulp gehad van Jo Wiertz, Peter Kelderman en later ook Frans Weekers van de Centrale Proefdier Voorziening. Mijn dank hiervoor.

Mijn dank gaat ook uit naar de medewerkers van de audiovisuele dienst van het AZM die met geduld mijn fotografische problemen wisten op te lossen. Ook de medewerkers van de universiteitsbibliotheek verdienen mijn dank voor hun medewerking.

Verder wil ik graag alle mensen bedanken die ik hier niet met name heb genoemd maar die zeker hebben bijgedragen aan de tot standkoming van dit proefschrift.

Uiteraard hoort hier ook een woord van dank ten aanzien van de leden van de becordelingscommissie, Prof. Dr. H.A.J. Struyker-Boudier, Prof. Dr. R.F.A. Zwaal, Prof. Dr. P.W. de Leeuw, Prof. Dr. J.J.M. Marx (Rijksuniversiteit Utrecht) en Prof. Dr. R.K. Jain (Harvard University, Boston, U.S.A).

I am grateful to Michael Giusiana for reading the proof of this manuscript, which definitely took perseverance.

Tenslotte wil ik Rens ten Hagen, ontwerper van de omslag van dit proefschrift, bedanken voor zijn enthousiasme waarmee hij een unieke bijdrage aan dit proefschrift heeft geleverd.

$\mathrm{Na}$ al deze woorden van dank is er nog iemand aan wie ik een aparte alinea wil wijden, nl. de eerste promotor en tevens auteur van dit project, Geert Blijham.

Beste Geert, ik wil je graag voor een aantal dingen bedanken. Allereerst heb ik van jou de kans gekregen om als AIO op dit project te beginnen. Verder heb je mij de ruimte en vrijheid gegeven om het werk op mijn eigen manier aan te pakken, met subtiele bijsturingen wanneer ik teveel tegelijk wilde doen. Daarnaast heb je me vrijwel onbeperkt de mogelijkheid gegeven om naar cursussen, congressen en symposia te gaan, wat inmiddels zo waardevol is gebleken. Dat er, na jouw vertrek naar Utrecht, minder tijd beschikbaar was voor mijn project werd ruimschoots gecompenseerd door de extra tijd die je hebt geînvesteerd tijdens de afronding van dit proefschrift. Ik zal altijd met veel plezier aan onze samenwerking terug denken en ik hoop dat dat wederzijds is.

$\mathrm{Na}$ bijna drie pagina's ben ik aan het eind gekomen van mijn nawoord. Rest mij alleen nog dit: lieve Joost, dank je wel... 


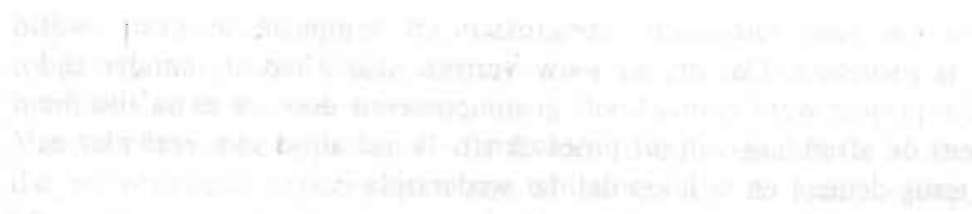

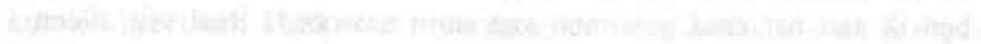

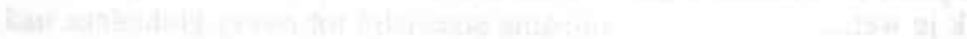
24k

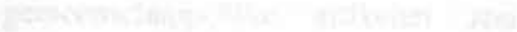

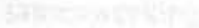

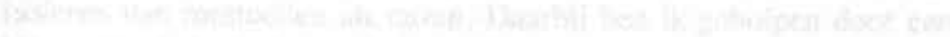

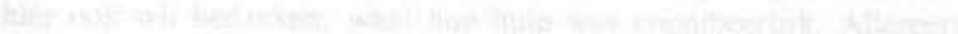




\section{List of Publications.}

- Lichtenbeld H.H.C., Vidic B. Effect of maternal exposure to smoke on gas diffusion capacity in neonatal rat. Resp. Physiol. 75 (2); 129-140, 1989.

- Lichtenbeld H.C., Blijham G.H. Tumor cell spheroids induce a mitogenic response in endothelial cells. In: Angiogenesis, Key Principles: Science-Technology-Medicine. R.Steiner, P.B. Weisz, R.Langer. Birkhäuser Verlag AG. Basel 1992; p. 261-265.

- Lichtenbeld H.C., Blijham G.H. Mitogenic properties of tumor spheroids for endothelial cells are related to their age. Endothelium 1993 (in press).

- Lichtenbeld H.C., Muller A.D., Van Dam-Mieras M.C.E., Blijham G.H. Tumor spheroid induced vesicle formation on endothelial cells is associated with procoagulant properties. J. Cell Sci. 1993 (accepted).

- Muller A.D., Lichtenbeld H.H.C., Vossen R.C.R.M., Blijhan G.H., Van Dam-Mieras M.C.E. Mast cells induce a procoagulañt response on endothelial cells. Thromb. Res. 1993 (accepted).

\section{Abstracts/Proceedings}

- Vidic B. Lichtenbeld H. Role of extracellular matrix proteins in determining postnatal patterns of the airblood barrier differentiation. Transplacental effect of tobacco smoke metabolites. J.Cell Biol. Vol. 107(6) par 3; 769a.

* Lichtenbeld HC, Blijham GH. Tumor cell spheroids cause endothelial cell proliferation in vitro. International Symposium on Angiogenesis, March 13-15, 1991, St. Gallen, Switzerland (abstract nr. 1).

* Lichtenbeld HC, Blijham GH. Tumor cell spheroids cause endothelial cell proliferation in vitro. NIV Intemistendagen 18-19 april 1991, Veldhoven.

* Lichtenbeld HC, Blijham GH, Muller AD, Van Dam-Mieras MCE. Tumorangiogenesis: endothelial cell = tumor cell interactions. NVVC, 28 november 1991, Amsterdam.

AlO-posterprijs 1991.

* Lichtenbeld HC. Tumorangiogenesis in vitro. Université de Nancy, 12 Mars 1992, dépariement de. pathologique, Nancy, France.

* Lichtenbeld HC. Education and actions of the LAIOO association. Proceedings of the Federation of Medical Scientific Societies p.22, 21-22 April 1992.

* Lichtenbeld HC, Muller AD, Van Dam-Mieras MCE, Blijham GH. Tumor cell induced vesicle formation on endothelial cells is associated with procoagulant properties. Eur.J.Cell Biol. Suppl.37 (vol.60) 1993.

* Lichtenbeld HC, Muller AD, Van Dam-Mieras MCE, Blijham GH. Coagulation disorders in cancer: an in vitro study. Thromb. Haemost. 69(6), 1039, 1993. 


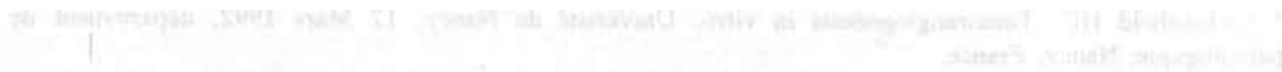

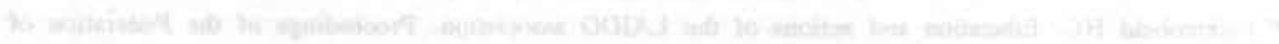

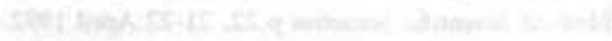

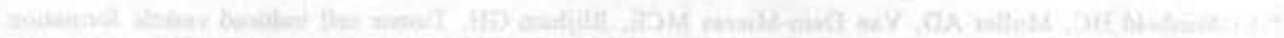

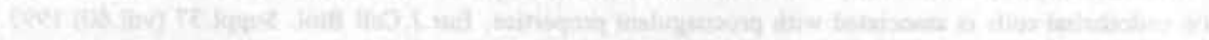

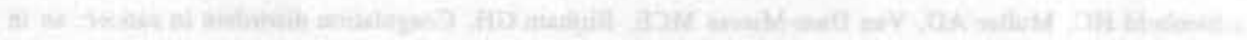

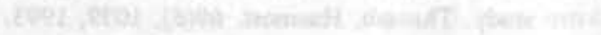




\section{Curriculum vitae}

Hera Lichtenbeld werd geboren op 4 maart 1962 te Rheden. Zij behaalde in 1980 het VWO-B diploma an de Revius Scholengemeenschap te Deventer. In de daarop volgende 4 jaar volgde zij de Hoger Beroeps Opleiding tot Verpleegkundige (HBO-V) te Nijmegen welke voltooid werd met een diploma in juni 1984. Van september 1984 tot november 1988 studeerde zij Gezondheidswetenschappen, afstudeerrichting Biologische Gezondheidkunde, aan de Rijksuniversiteit Limburg te Maastricht. Het onderzoek voor haar afstudeerstage verrichtte zij bij Dr. B. Vidić, Georgetown University, Washington DC, USA. De contacten opgedaan tijdens deze periode hebben geleid tot een samenwerkings project dat thans wordt uitgevoerd.

$\mathrm{Na}$ het behalen van haar doctoraal diploma in november 1988 trad de auteur per 1 januari 1989 in dienst als assistent in opleiding (AIO) aan de Rijksuniversiteit Limburg bij de vakgroep Inteme Geneeskunde bij Prof.Dr. G.H. Blijham (sinds januari 1992 werkzaam in het Academisch Ziekenhuis Utrecht), alwaar zij aan de tot standkoming van het huidige proefschrift heeft gewerkt in samenwerking met Prof.Dr. M.C.E. van Dam-Mieras van de Open Universiteit in Heerlen. Voor een deel van dit werk ontving de auteur in november 1991 de AIO-posterprijs van de Nederlandse Vereniging voor Celbiologie.

Naast haar werk als AIO is de auteur gedurende twee jaar $(1990-1992)$ voorzitter van het Landelijk AIO Overleg (LAIOO) en tevens penningmeester van de plaatselijke AIOvereniging (AVRL) geweest. 
